\title{
Building an Image: Japanese Influence on the Perception of Western Countries, A Study of the 1904 St. Louis World's Fair
}

Andrea M. Fowler

West Virginia University, amf0024@mix.wvu.edu

Follow this and additional works at: https://researchrepository.wvu.edu/etd

Part of the Asian Art and Architecture Commons, Modern Art and Architecture Commons, and the Theory and Criticism Commons

\section{Recommended Citation}

Fowler, Andrea M., "Building an Image: Japanese Influence on the Perception of Western Countries, A Study of the 1904 St. Louis World's Fair" (2019). Graduate Theses, Dissertations, and Problem Reports. 7425.

https://researchrepository.wvu.edu/etd/7425

This Thesis is protected by copyright and/or related rights. It has been brought to you by the The Research Repository @ WVU with permission from the rights-holder(s). You are free to use this Thesis in any way that is permitted by the copyright and related rights legislation that applies to your use. For other uses you must obtain permission from the rights-holder(s) directly, unless additional rights are indicated by a Creative Commons license in the record and/ or on the work itself. This Thesis has been accepted for inclusion in WVU Graduate Theses, Dissertations, and Problem Reports collection by an authorized administrator of The Research Repository @ WVU. For more information, please contact researchrepository@mail.wvu.edu. 


\title{
Building an Image: \\ Japanese Influence on the Perception of Western Countries, A Study of the 1904 St. Louis World's Fair
}

\author{
Andrea Fowler \\ Thesis submitted to the \\ College of Creative Arts \\ at West Virginia University \\ in partial fulfillment of the requirements \\ for the degree of
}

\author{
Master of Arts \\ In \\ Art History
}

\author{
Rhonda Reymond, Ph. D., Chair \\ Kristina Olson, M.A. \\ Janet Snyder, Ph. D. \\ School of Art and Design \\ Morgantown, West Virginia \\ 2019
}

Keywords: Louisiana Purchase Exposition, World's Fair, The Ainu, Geisha, Reception Theory, Japan, Tea Ceremony, 1904

Copyright 2019 Andrea Fowler 


\title{
Abstract \\ Building an Image: \\ Japanese Influence on the Perception of Western Countries, A Study of the 1904 St. Louis World's Fair
}

\begin{abstract}
Andrea Fowler
In this thesis, I argue that the Japanese government has utilized art and artistic expression to influence the perception that Western countries had of its nation and culture. This phenomenon is examined through a case study of Japanese participation at the 1904 St. Louis World's Fair, and the exhibits that they presented. These exhibits are examined utilizing both reception and post-colonial theory, and then applying these theories to primary source material from the 1904 World's Fair. These materials include guidebooks and photographs from both the United States and Japanese authors, to showcase differences between how the East and West interpreted these exhibits. Two specific examples that illustrate this point are the Japanese relationship with the indigenous population the Ainu and the presentation of Geisha as an embodiment of Japanese culture. Through this analysis, I draw a relationship between the Japanese government's self-represented identity and this identity's reception by Western authors. This research concludes that the Japanese government influenced the perception of Western countries through their participation at the 1904 World's Fair, and carefully cultivated an image of their culture that was beneficial to their international goals. This thesis helps to shed light on Japan's interactions with the Western world after their return to the world's stage, and the importance of using art to influence international perceptions of their national identity.
\end{abstract}




\section{ACKNOWLEDGMENTS}

I would first like to thank my thesis advisor Dr. Rhonda Reymond from the College of Creative Arts at West Virginia University. Dr. Reymond was always available to assist me whenever I had a question or needed to talk through the development of the paper. She consistently helped me hone my ideas and steered me in the right direction whenever I was struggling with how to move forward.

I would also like to thank Professor Kristina Olson from the College of Creative Arts at West Virginia University. Without her insightful feedback and input, I would not have been successful at constructing the theoretical arguments in my thesis.

I would also like to acknowledge Dr. Janet Snyder from the College of Creative Arts at West Virginia University. I am grateful and indebted to her for her valuable comments on this thesis.

I would like to show my gratitude for the financial support of the Margaret Tavenner Rajam Art History Endowment Student Travel Fund. Without their care and funding, it would have been impossible to complete the research necessary for my thesis.

I would like to thank my parents for their guidance, patience, and support. The example they set for me, and their focus on the importance of education, provided me with the foundation to complete this thesis.

Finally, to my partner Tyler, I must express my profound gratitude for his unfailing support and continuous encouragement throughout my years of study and through the process of researching and writing this thesis. This accomplishment would not have been possible without him. 


\section{Table of Contents}

$\begin{array}{lll}\text { Abstract } & \text { ii }\end{array}$

$\begin{array}{ll}\text { Acknowledgements } & \text { iii }\end{array}$

List of Figures $\quad$ v

$\begin{array}{ll}\text { Introduction } & 1\end{array}$

1. Literature Review 3

2. Japanese History and Previous World's Fairs $\quad 8$

3. Reception, Post-Structuralist, and Post-Colonial Theory 19

4. The 1904 World's Fairs $\quad 27$

5. Japan's Aesthetic Portrayal and Reception at the Fair 35

$\begin{array}{ll}\text { 6. The Ainu } & 49\end{array}$

$\begin{array}{ll}\text { Conclusion } & 59\end{array}$

$\begin{array}{ll}\text { Figures } & 61\end{array}$

$\begin{array}{ll}\text { Bibliography } & 87\end{array}$ 
List of Figures (using original names when provided)

Figure

1. Interior of a Bathhouse $\quad 74$

2. Under the Wave off Kanagawa (The Great Wave) 74

3. Plum Estate, Kameido (Kameido Umeyashiki) 75

4. Flowering Plum Orchard (after Hiroshige) 75

5. La Japonaise 76

6. The courtesan (after Eisen) 76

$\begin{array}{ll}\text { 7. Lakeside } & 77\end{array}$

8. Reminiscence of the Tempyo Era 77

9. Pharus-map World's Fair St. Louis 78

10. Floor Plan to West art pavilion of the Palace of Fine Arts 78

$\begin{array}{ll}\text { 11. Golden Eagle Statue } & 79\end{array}$

12. Japanese Exhibit in Palace of Varied Industries 80

13. "The Japanese Representation." 80

14. Birdseye View of the Japanese Garden 81

15. Pavilion, and Specimen of Landscape-Gardening 82

16. Japanese Gardens and Tea-Houses St. Louis $\quad 82$

17. The Spider Play in Fair Japan. St. Louis 83

18. Entrance to Fair Japan. St. Louis 83

19. "Fair Japan" advertisement 84

20. The Princess from the Land of Porcelain 85

21. Geisha Girls in Fair Japan. St. Louis 86

22. Types of People- Japanese Ladies and Children. St. Louis 86

23. Japanese Girls in the Garden, St Louis Fair 87

24. Japanese Garden at the World's Fair $\quad 87$

25. Interior of Japanese Home

26. Drinking Tea in a Japanese Pavilion. St. Louis 88

27. Japanese Ensemble $\quad 89$

28. The Ainu Group (At Tokio) 89

29. Yazo of Sapporo 90

30. Shirake, wife of Yazo 90

31. Shirake 90

32. Map of Hokkaido $\quad 91$

33. Bete Goro of Sapporo 91

34. Map of a section of the southwest coast of Hokkaido 91

35. Kutoroge of Piratori 92

36. Shutratek, wife of Kutoroge 92

37. Kiko, daughter of Kutoroge and Shutratek 92

38. Sangyea of Piratori 93

39. Santukno, wife of Sangyea 93

40. Kin, daughter of Sangyea and Santukno $\quad 93$

41. Hairy Ainu From Far North 94 
42. Ainu woman wearing attush garment with magical embroidery 94

43. Woman's Dress of Elm-Bark Cloth, Earrings, and Necklace 95

44. Ainu forearm tattoos 96

45. Women Pounding Millet 96

46. Interior of the Ainu house at the Louisiana Purchase Exposition 97

47. Ainu mother and child 97

48. House in Demolution: Shiraoi 98

49. The three Ainu women using a mortar and pestles 98

50. Ainu Weaver 99

51. The Ainu group at the Louisiana Purchase Exposition 99 


\section{Introduction}

This thesis analyzes the aesthetic focus that the Japanese government employed at the 1904 St. Louis World's Fair. I make the argument that the Japanese government utilized art and display decisions to influence the perception of their nation and culture by Western countries. At the Fair, Japan strove to construct its identity and present itself to the West as a modern state. By integrating both traditional Japanese values and new Western influence, Japan attempted to design a space in the international community for itself that was distinct. My research culminates in a comparison between Japanese and American guidebooks and examines the racial tones and cultural misunderstandings examined in this thesis. The language used in the guidebooks supplements a visual analysis of the photographs discussed in the paper.

Two specific examples utilized to illustrate this point are the Japan's relationship with its indigenous population, the Ainu, and their presentation of Geisha as an embodiment of Japanese culture. These photographs showcase the visual elements that create a structure for the relationship between Japan's self-portrayal and the reception by the United States. Through this analysis, I draw a relationship between the Japanese government's self-represented identity and reception by Western authors. The lens of Reception and Post-colonial theory are employed to examine the primary source and how they connect with the theoretical discussion.

This thesis relied on primary documents published during the Fair and immediately after. These are supplemented by secondary resources that were used to analyze the Fair through an historical lens. Guidebooks and handbooks from the Fair serve as indicators of the difference in perception, in part, based on whether the author was from the United States or from Japan. The distinctly different descriptions and discussions serve to provide a deeper insight into the developing perspective and understanding of Japan and its culture at the beginning of the 
twentieth century. The primary source photographs from the Fair: of Geisha, tea ceremonies, and the Ainu provided the material for the visual analysis. Post-Colonial theory offers a text to examine an oppressed/colonized population strives to maintain its own cultural identity Opposite the picturesque idea of Japan presented at the Japanese exhibits was the showcasing of the indigenous population the Ainu. Chapter six considers the situation with the Ainu, and how it was used to affect the perception of Japan and subsequently their attempt to appear as a colonizing power; a relatable position for the West. The Ainu had a complicated relationship with the Japanese government and faced the oppression of their culture and way of life. This was like many Western countries', including the United States' handling of indigenous populations; and similarly, Japan attempted to control and regulate the Ainu.

This research concludes that the Japanese government influenced the perception of Western countries through its participation at the 1904 World's Fair, and carefully cultivated an image of its culture that was beneficial to their international image and goals. This thesis helps to shed light on the interactions between Japan and Western nations after Japan entered the international stage. It also examines the importance of the use of art to influence international perceptions of Japan's national identity. This research showcases the importance of guidebooks for the examination of cultural, racial, political, and societal perspectives at the time of their first publication. 


\section{Chapter 1: Literature Review}

This thesis focuses on primary documents published during and immediately after the 1904 St. Louis World's Fair. These texts provide photographs and perspectives of Japan by the United States at the time of the Fair. Guidebooks and handbooks serve as indicators of the difference in perception of the Fair based on whether the author was from the West or from Japan. The descriptive words used in these documents provide a means to examine the tone and context for the cultural outlook on Japan by the West in comparison to the Japanese perspective of the Fair. The distinctly different descriptions and discussions serve to provide a deeper investigation into the developing perspective and understanding of Japanese culture by the United States. The primary documents are supplemented with secondary sources that are applied to examine the Fair through a different lens capable of identifying the cultural biases of the time.

World's Fairs have been examined as an overarching event by authors such as Robert Rydell, an authority on the examination of these exhibitions. Rydell describes the importance of Fairs in Fair America: World's Fairs in the United States (2000) stating that "World's Fairs have exerted a formative influence on the way Americans have thought about themselves and the world in which they live probably understates the importance of those expositions." ${ }^{\text {He further }}$ discusses the hegemonic functions of the Fairs extensively in All the World's Fair: Visions of Empire at American International Expositions (1984), focusing on how the "country's political, financial, corporate, and intellectual leaders offered these ideas as the proper interpretation of social and political reality."2 Rydell examines Western participation in various Fairs and discusses the political, financial, corporate, and intellectual impact on United States' politics and

\footnotetext{
${ }^{1}$ Robert W Rydell, John E Findling, and Kimberly D Pelle, Fair America: World's Fairs in the United States, Washington, DC: Smithsonian Institution Press, 2000,1.

${ }^{2}$ Robert W Rydell, All the World's Fair: Visions of Empire at American International Expositions, 1876-1916, Chicago: University of Chicago Press, 1984, 3.
} 
social reality. ${ }^{3}$ Other authors, such as Peter Hoffenberg agrees with Rydell on the important impact the Fairs had on American society. Hoffenberg examines the "social and political forces, institutions, and persons shaping the display and observation of objects and people at the popular exhibitions," in his work An Empire on Display (2001). ${ }^{4}$

Rydell and Hoffenberg also delve into the racial exploitation and treatment of minorities in the context of the Fairs. Rydell examines the impact of scientific 'evidence' that was created to maintain racial norms of the period. ${ }^{5}$ Hoffenberg focused on the "rise of colonial nationalism and the opportunity to form national identities at the exhibitions;" examining the social questions that arose from World's Fairs. ${ }^{6}$ The intercultural interactions and impact of the colonial perspective are discussed by John Burris in his work Exhibiting Religion: Colonialism and Spectacle at International Expositions, 1851-1893 (2001).

Burris discussed the broad-reaching intercultural interactions that were facilitated by the World's Fairs. He further discussed the commercial motivations of the Fairs and how the interactions that occurred were "unique within the history of Western thought." ${ }^{7}$ Burris furthered his argument with the perspective of French historian Fernand Braudel stating that "Braudel has pointed to the importance in historical analysis of what he calls "conjecture" the creative but explosive effervescence that appears when long developing cultural traditions come into close and extended contact with one another." ${ }^{8}$ He further states that "This phenomenon occurred in an

\footnotetext{
${ }^{3}$ Ibid., 3.

${ }^{4}$ Peter H. Hoffenberg, An Empire on Display: English, Indian, and Australian Exhibitions from the Crystal Palace to the Great War, Berkeley: University of California Press, 2001.xxii/preface.

${ }^{5}$ R.W. Rydell, All the World's Fair: Visions of Empire at American International Expositions, 1876-1916. (Chicago: University of Chicago Press, 1984), 2.

${ }^{6}$ Hoffenberg, An Empire on Display: English, Indian, and Australian Exhibitions from the Crystal Palace to the Great War, xxii/preface.

${ }^{7}$ John P. Burris, Exhibiting Religion: Colonialism and Spectacle at International Expositions, 1851-1893, Studies in Religion and Culture, Charlottesville: University Press of Virginia, 2001, 1.

${ }^{8}$ Ibid., 1 .
} 
extreme and largely unprecedented way at the international expositions and is pivotal in attempting to understand the structure of international expositions and the power with which the events were invested." 9

The interactions of developing cultural traditions that Braudel and Burris discuss are built on by authors such as Zeynep Çelik and Miya E. Mizuta. Celik focused on the concepts of exoticism and orientalism in his work Speaking Back to Orientalist Discourse (2014), stating that "Exoticism, the dominating theme among late nineteenth- century American perceptions of the "Orient", owed a great deal to the "authentic" sets designed for the World's Fairs and peopled by true "natives". ${ }^{10}$ Mizuta examined the way that Japan harnessed the colonial/orientalist perspectives in Western thought to its benefit, in the context of the 1904 St. Louis Fair. In her article 'Fair Japan': On Art and War at the Saint Louis World's Fair, 1904 (2006), Mizuta discusses the impact Japan's art exhibition had at the Fair by engaging the texts "The Inebriated Beauty" written by Nagai Kafū (1879-1959), which was originally given as a presentation at the Fair, and "Modern Problems in Painting" written by Okakura Kakuzo (1863-1913), that also took place at the Fair. ${ }^{11}$

Mizuta's article also discusses the importance of Japanese women in art and the impact they had on Japanese art and on the perception of Japan by the people in the West stating that "While the myth of the Japanese woman as an art object was being disseminated outside of Japan, circulating widely in the West, notions such as 'Beauty is a woman' and 'Women are artworks' - notions and representations of women foreign to Japan's cultural repository - were

\footnotetext{
${ }^{9}$ Ibid., 1.

${ }^{10}$ Zeynep Çelik and Jay, Martin. "Speaking Back to Orientalist Discourse," Essay, In Speaking Back to Orientalist Discourse, 395-414, 2014, 77.

${ }^{11}$ Miya E. Mizuta, "Fair Japan: On Art and War at the Saint Louis World's Fair, 1904”, Discourse, Vol. 28.1, 2006. 29.
} 
being evaluated at home in Japan."12 There is also an examination of the interactions between the East and the West and the ways that women perceived as an art object influenced those relations. Mizuta described the construction of Japan's international identity as "Caught between two aspirations, to remain particular (as a symbol of national Japanese identity), yet universal (in order to be accepted in the global con figuration), in the Meiji period the figure of the bijin evoked what could be described as a schema of configuration. That is, the beautiful woman figured in the construction of a modern Japanese identity that did not develop unilinearly but was conceived of in relation to others." ${ }^{13}$ This is especially important to this paper, because it examines the real-world influences on the decisions Japan made for the Fair and how those were received. The perception of Japanese women as art by the West impacted Japanese governmental decisions and the choices on the construction of a Japanese identity to present to the world. The article "The Gender of Nationalism: Competing Masculinities in Meiji Japan" (2002) by Jason G. Karlin also provides a basis of knowledge of the cultural circumstances of Japan at the time of the Fair. ${ }^{14}$ He examines the importance of the representation of women and gender during the Meiji era in Japan, helping to build a contextual understanding of how Japanese women were perceived in Japan and how these perceptions influenced the countries interactions with the West.

This research is supported by pertinent literature that examines the perspectives that the United States and Japan presented at the Fair. There has been extensive research on World's Fairs, but there has not been a focus on the impact of the guidebooks that were created for each

\footnotetext{
12 Ibid., 46.

${ }^{13}$ Ibid., 46.

${ }^{14}$ Jason G. Karlin, "The Gender of Nationalism: Competing Masculinities in Meiji Japan," Journal of Japanese Studies 28, no. 1, 2002, 41.
} 
fair. These books provided a lens for historians to look back at fair reception, exhibit reactions, and strategic decisions made by fair organizers. This thesis contributes to the existing literature by analyzing reception and perception at the time of the Fair, using guidebooks. Guidebooks also provided the viewpoints of their author and often the first-hand accounts of people visiting the fair. In the next chapter, the conditions that premediated the 1904 Fair are discussed further. This includes an examination of the influence of Japanese art and culture and exposure at previous Fairs.

In conclusion, Miya E. Mizuta states that “The success of Japan's art exhibitions at the St. Louis World's Fair, 1904, earned Japan the reputation of being considered "one of the first nations of the world."' 15 I argue that the Japanese government utilized their artistic expression as a means to influence the perception of Western countries. Through my analysis, I draw a relationship between the Japanese government's self-represented identity and this identity's reception by Western authors, using the 1904 World's Fair as a platform. World's Fairs were strategic venues where countries could cultivate an image of their culture that was beneficial to their international goals.

${ }^{15}$ Mizuta, “Fair Japan: On Art and War at the Saint Louis World's Fair, 1904,” 28. 


\section{Chapter 2: Japanese History and Previous World's Fairs}

\section{Japanese History preceding the 1904 Fair}

In the mid-nineteenth century, the United States was determined to open trade ports with Japan. ${ }^{16}$ These ports would also serve as refueling stations for ships in the Pacific. ${ }^{17}$ Japan had traditionally been opposed to opening their ports which led the United States to send a squadron of ships to force the Japanese government to acquiesce. ${ }^{18}$ Commodore Perry (1794-1858) led the expedition and presented the Japanese emperor with various gifts that were meant to showcase the superiority of Western culture. ${ }^{19}$ The Japanese government begrudgingly agreed to open their borders, signing the Treaty of Kanagawa on March 31, $1854 .{ }^{20}$

The period that followed the opening of Japan to the United States in known as the Meiji Restoration (1868). Major changes occurred socially and politically to move Japan into the modern era. The government shifted away from a feudal society by assimilating Western values, such as: a market economy, a Westernized military, and a constitution. ${ }^{21}$ The movement away from a feudal society and toward modernization created an interest in international perception and interpretation of Japan by the Japanese. By integrating both traditional Japanese values and new Western influence, Japan designed a space in the international community for itself. A focus on aesthetic values allowed Japan to structure its perception by the West. This restructuring provided a means for Japan to modernize the country and military while striving to maintain its traditional identity. New policies formed the core of the Japanese idea of a prosperous nation and

\footnotetext{
${ }^{16}$ The United States and the Opening to Japan, 1853, Office of the Historian, Foreign Service Institute United States Department of State, 2019, https://history.state.gov/milestones/1830-1860/opening-to-japan.

${ }^{17}$ Ibid.

${ }^{18}$ Ibid.

${ }^{19}$ Ibid.

${ }^{20}$ Ibid

${ }^{21}$ W.G. Beasley, The Meiji Restoration. Stanford, Calif: Stanford University Press, 1972, 305-306.
} 
a strong military. ${ }^{22}$ The adoption of Western values also influenced Japanese policy and perspective on modernization.

Japan also began assimilating Western culture, much to the horror of Western supporters of Japanese art. ${ }^{23}$ For some artists, the influence of the West began to eat away at the traditions that were so valued. ${ }^{24}$ Ernest Francisco Fenollosa (1853-1908) was an American art historian of Japanese art concerned with the preservation of traditional methods and themes of Japanese art and a driving force behind emerging American interest in Japanese art and culture. ${ }^{25}$

During the decades following the Treaty of Kanagawa (1854), Japan aggressively used its military against its neighboring countries, this included: China, Korea, and Russia. ${ }^{26}$ This military doctrine was not the sole perception that Japan sought to portray to the world, and instead emphasized its artistry, culture, and technological/mechanical innovations in its Fair exhibitions.

After the country was forcibly opened (1852-1854), the Japanese government concluded that the country was trailing the technological advancements of the West. During the years following the United States forceful opening of Japanese ports, the Japanese government sent an Embassy comprised of thirty-eight members to attend The International 1862 World's Fair in London. ${ }^{27}$ This group was led by Yasunori Takeuchi, the governor of the Shimotsuke region at

\footnotetext{
22 Ibid., 313.

${ }^{23}$ Ibid., 41.

${ }^{24}$ Ibid., 41.

${ }^{25}$ D. Jenkins, Images of a Changing World: Japanese Prints of the Twentieth Century, Portland Art Museum, 1983.

${ }^{26}$ Drea, Edward J., Japan's Imperial Army: Its Rise and Fall, 1853-1945, Kansas: University Press of Kansas, 2009.

${ }^{27}$ In this context the Japanese Embassy is the title for the emissaries that attended the 1862 World's Fair. See also, National Diet Library, Second London International Exposition of 1862, 2010,

http://www.ndl.go.jp/exposition/e/s1/1862-1.html. (accessed: 09/15/2017)
} 
the time. ${ }^{28}$ The Embassy visited to discuss a postponement of a full opening of Japanese borders to the West.

While there was no official Japanese exhibit at the 1862 Fair, a British diplomatic representative to Japan, R. Alcock had displayed several items of interest from Japanese culture. ${ }^{29}$ This was the first time that Japan had been represented at a World's Fair. The attending Japanese embassy was not impressed by the pieces presented. ${ }^{30}$ Tokuzo Fuchibe, a member of the embassy lamented that the display "had been like old bric-a-brac and that all the Japanese exhibits had been very shabby." 31 While visiting, the embassy paid close attention to the other exhibits and the industrial demonstrations, taking note of what made a successful layout. ${ }^{32}$ The visit to the 1862 Fair would provide starting point for Japan's structuring of its exhibits at future Fairs.

In the early years after Japan was opened to the West, there was very little information available about Japan in the West. ${ }^{33}$ This provided an opportunity for Japan to influence how Western countries perceived Japanese culture and values. This created a unique opportunity to control information that had not been accessible to other foreign powers up until that point. ${ }^{34}$

The Influence of Ukiyo-E

An important influence on the Western perception of Japan were Ukiyo-e woodblock prints (Figures 1,2, and 3). Each of these prints was owned be famous artists working in Europe.

\footnotetext{
${ }^{28}$ Ibid.

${ }^{29}$ Ibid.

${ }^{30}$ Ibid.

${ }^{31}$ Ibid.

${ }^{32}$ Ibid.

${ }^{33}$ Priscilla Clapp and Joint Committee on Japanese Studies, Mutual Images: Essays in American-Japanese Relations, Edited by Akira Iriye, Harvard Studies in American-East Asian Relations, 7. Cambridge: Harvard University Press, 1975, 25.

${ }^{34}$ Ibid., 25.
} 
Interior of a Bathhouse, (1787), Torri Kiyonaga and was owned at one point by Edgar Degas. ${ }^{35}$ The print portrays a group of women in various stages of undress, partaking in a public bath. Degas was particularly inspired by the curvilinear figures that are juxtaposed with the horizonal and vertical lines in the composition. The print Under the wave of Kanagawa (also known as The Great Wave), 1830-32 by Katsuhika Hokusai is one of the most recognizable Japanese prints. Claude Monet had a copy of Under the wave of Kanagawa hanging in his home and was an avid collector of Japanese prints. Other artists that were collecting Hokusai prints included: Paul Gauguin, Auguste Rodin, Edgar Degas, Gustave Klimt, Edouard Manet, Franz Marc, and Vincent Van Gogh. Another important print was Plum Estate, Kameido, 1857 by Utagawa Hiroshige. Van Gogh was heavily influenced by Hiroshige and the Plum Estate print; he created a painting that was inspired by the piece called Flowering Plum Orchard (after Hiroshige)

(Figure 4).

The rise in popularity of Ukiyo-e (which translates to 'floating world' in English) in Japan was due to the rapid economic growth that occurred when Edo (present day Tokyo) became the government capital in $1868 .^{36}$ This economic growth enabled an expansion of the middle class, such as merchants, who had the money to decorate their homes. Furthermore, this increase in funds also allowed merchants to afford entertainments such as going to the theater, and Geisha. Not all in the country were fond of this cultural shift, and the term "Ukiyo" was often used to describe what many believed to be more hedonistic lifestyle. ${ }^{37}$

\footnotetext{
${ }^{35}$ Museum of Fine Art Boston. Interior of a Bathhouse, https://collections.mfa.org/objects/467811 (Accessed November 30th, 2019).

${ }^{36}$ David Bell, Ukiyo-e Explained. Folkestone, Kent: Global Oriental, 2004, X.

${ }^{37}$ Ibid., X.
} 
Sometime in the 1860s, Ukiyo-e began to decline in Japan. The decline coincided with drastic social and technological modernization of Japan that occurred during the Meiji Restoration of 1868 , which was linked to the sharp decline in public interest. ${ }^{38}$ Around that time, artists throughout Europe were discovering the imagery of Japan and being influenced. Paintings such as La Japonaise by Claude Monet and The courtesan (after Eisen) by Vincent Van Gogh showcases imagery that is distinctly influenced by Japanese art and object. The images of the pleasure quarter and what was considered as hedonistic in Japan became a major factor in the perception of Japanese culture and society by the West. ${ }^{39}$

Following Japan's opening to the West the Japanese struggled socially and politically as Japan joined the international stage, this time was known as the Meiji Restoration. The Japanese government shifted away from being a feudal society by assimilating Western values, such as: a market economy, a Westernized military, and a constitution. ${ }^{40}$ The movement away from a feudal society and toward modernization created an interest in international perception and interpretation of Japan by the Japanese. By integrating both traditional Japanese values and new Western influence, Japan designed a space in the international community for itself. This restructuring provided a means for Japan to modernize the country and military while striving to maintain its traditional identity. New policies formed the core of the Japanese idea of a prosperous nation and a strong military. ${ }^{41}$ The adoption of Western values also influenced Japanese policy and perspective on modernization.

Japanese art students had begun studying yōga (Japanese style of painting made in accordance with European conventions) (Figures 7 and 8), which was the Western style of oil

\footnotetext{
${ }^{38}$ Ibid., 3.

${ }^{39}$ Ibid.

${ }^{40}$ W.G. Beasley, The Meiji Restoration. Stanford, Calif: Stanford University Press, 1972, 305-306.

${ }^{41}$ Ibid., 313.
} 
painting. ${ }^{42}$ This was approved of by the Bunten (Japanese Ministry of Education) ${ }^{43}$ The branch of the Japanese government that made the education decisions and assessed what styles of art the government supported. ${ }^{44}$

Traditional Japanese painting had begun around the seventh century and coincided with the introduction of sumi ink paintings from China. ${ }^{45}$ In the Heian period (794-1185), Japanese painting became known as yamato-e, and generally consisted of paintings on large scrolls. Later, during the Edo period (1603-1867), Ukiyo-e was developed. ${ }^{46}$ This was a departure from many of the traditional techniques from the Heian period with a focus on woodblock printing that had a more commercial interest. At the end of the nineteenth century the Nihonga style was developing in Japan.$^{47}$ Nihonga took many of the techniques from traditional Japanese painting and built on them to form a style distinctly separate from yōga.

By creating a specifically Japanese style there was an effort to preserve the identity of Japanese art perceived to be uninfluenced by Western culture. Matthew Larking discussed the relationship between Japanese and European styles of painting stating that "From the early 1880s, painting in Japan became bisected. Yōga was used to categorize works in oils that were inspired by European painting movements and nihonga became the umbrella term for an array of earlier Japanese painting traditions that were later modernized." ${ }^{, 48}$ During the 1880s, Fenollosa worked with Japanese artists to revive the traditional Japanese style of painting, helping to establish support for Nihonga. The struggle between European and Japanese artistic styles was indicative of the adjustments Japan was navigating during this period of modernization.

\footnotetext{
${ }^{42}$ Ibid.

${ }^{43}$ Ibid.

${ }^{44}$ Ibid.

${ }^{45}$ Ibid.

${ }^{46} \mathrm{Ibid}$.

${ }^{47}$ Mizuta, "Fair Japan," 41.

${ }^{48}$ Matthew Larking, "Nihonga didn't ignore the West." Tokyo: Japan Times, 2015.
} 


\section{A Militarized Japan}

While social and artistic change occurred, Japan also began constructing a Westernized military and strove to be recognized alongside Western nations. ${ }^{49}$ The St. Louis World's Fair became an important stage for Japan to balance the portrayal of its military conquests with portraying an appealing aesthetic identity to the West. While Japan went to war multiple times leading up to and during the 1904 World's Fair, it was not perceived primarily as a threatening militaristic power. This controlled identity seems to have allowed Japan to attempt to shape how its military strength, modernization, and cultural identity were portrayed to the United States.

The Japanese government endeavored to advance its military and technological abilities through trade. ${ }^{50}$ To modernize its military, Japan requested aid to help train its soldiers from Western countries such as the United States and France ${ }^{51}$ Part of training included the creation of an Imperial army and the dissolution of the Samurai class. ${ }^{52}$ Japan instigated multiple conflicts in the 1890s and early 1900s. ${ }^{53}$ Each of these conflicts served to help Japan strengthen its military and solidify its dominance in Asia, setting Japan apart from other Asian countries, in a militaristic sense.

The Sino-Japanese war that had ended in 1895 was an important factor in the perception of Japanese modernization. ${ }^{54}$ The conflict had been fought for control and influence over Korea, and was one of the first situations where their military could truly be tested, and it was a resounding success for Japan. ${ }^{55}$ While Japan had been working to integrate Western innovation

\footnotetext{
${ }^{49}$ Beasley, The Meiji Restoration, 364.

${ }^{50}$ Ibid., 364.

${ }^{51}$ Ibid., 364.

${ }^{52}$ Ibid., 364-365.

${ }^{53}$ J. Rickard, First Sino-Japanese War (1894-1895), October 31, 2013. http://www.historyofwar.org/articles/wars_first_sino_japanese.html

${ }_{54}$ Ibid.

${ }^{55}$ Ibid.
} 
and modernization, Korea ignored the West and remained secluded. China also chose to stay isolated, which caused them to struggle after facing conflict with Japan. ${ }^{56}$ These conquests appeared to showcase Japan's westernized military decisively beating China and Korea, which had not integrated westernized military structures in the same way.

Japan's strengthening military prowess eventually prompted them to start a conflict with Russia, resulting in the Russo/Japanese War in 1904-05. Japan used the 1904 World's Fair as a platform to gain support in the Russo/Japanese War, while tensions were rising. ${ }^{57}$ After Russia belatedly decided not to come to the Fair, Japan took over a large chunk of exhibition space that was originally meant for Russia. ${ }^{58}$ Japanese Geisha working at the tea house would speak to visitors and invite them to the Japanese restaurant to celebrate their battle victories over Russia. ${ }^{59}$ During the Fair, Japan tried to build a positive public opinion in the West; to gain America's approval of its actions against Russia. "When a reporter asked a Japanese attendant why Manchuria was not represented, he was told to "wait a little, the war is not over." 60 Japan defeated Russia soon after the 1904 World's Fair. The Japanese government's participation at the Fair was an effective tool in strengthen their credibility with Western countries.

\section{Previous World's Fairs}

Japan balanced the Western perception of the 'feminized orient' and its artistic achievements, with modernization; and military prowess, to bolster its ability to try to control the perception of its identity and influence reception in the West. Japan attempted to use the World's

\footnotetext{
${ }^{56}$ Ibid.

${ }^{57}$ Louisiana Purchase Exposition Saint Louis, Mo. and Koji Oi. Louisiana Purchase Exposition, St. Louis in 1904: A Collection of Official Guidebooks and Miscellaneous Publications. Kyoto: Eureka Press, 2009.

${ }^{58}$ Carol Ann Christ, ""the Sole Guardians of the Art Inheritance of Asia": Japan at the 1904 St. Louis World's Fair," Positions: East Asia Cultures Critique 8, no. 3, 2000, 675-709.

${ }^{59}$ Ibid.

${ }^{60}$ Ibid.
} 
Fairs as a platform to shape its perception by the West. Fascination with Japan in Western countries was likely fueled by exposure at previous World's Fairs such as the London International Exposition of 1862, the Exposition Universelle of 1867 in Paris, the Vienna International Exposition of 1873, and the Centennial International Exhibition of 1876 in Philadelphia.

The 1867 Exposition Universelle was the second Fair in Paris and was made up of fortytwo nations and was attended by roughly nine million people. ${ }^{61}$ The 1867 Fair was the first where Japan had its own pavilion, presented by the Satsuma and Saga domain of the Shogunate, even though there had been a Japanese presence at previous Fairs. ${ }^{6263}$

In 1873, the Vienna International Exposition took place in Austria. ${ }^{64}$ This was the first exposition in which the modern Japanese government of the Meiji period officially participated. ${ }^{65}$ Through this exhibition, the Japanese government hoped to present Japan as a cultured and industrially developed nation to the rest of the world. ${ }^{66}$ For the Japanese Pavilion a Shinto shrine, Japanese garden, music and dance hall and an arched bridge were all constructed for the event. Ukiyo-e prints and industrial art projects were placed separately from the Japanese Pavilion and were in the Industrial Pavilion. ${ }^{67}$ The Japanese garden was so popular that the

\footnotetext{
${ }^{61}$ Ibid.

62 Ibid.

${ }^{63}$ Satsuma is a Japanese domain of the Edo period. It is associated with the provinces of Satsuma, Ōsumi and Hyūga in modern-day Kagoshima Prefecture and Miyazaki Prefecture on the island of Kyūshū. Saga was a Japanese domain in the Edo period. It is associated with Hizen Province in modern-day Saga Prefecture on the island of Kyushu.

${ }^{64}$ National Diet Library, Vienna International Exposition of 1873, 2010. http://www.ndl.go.jp/exposition/e/s1/1873-2.html.

${ }^{65} \mathrm{Ibid}$.

${ }^{66}$ Clapp, 27.

${ }^{67}$ National Diet Library, Vienna International Exposition of 1873.
} 
Alexander Park Company, a British trading company, bought all the structures in the garden as well as all the trees and decorative stones after the Fair ended. ${ }^{68}$

Before 1876, Japan had been represented by individuals or decided to participate in the Fair late, leaving little time to have everything shipped to the Fair location and installed. For the 1876 World's Fair Japan made the decision to participate in the Fair in $1874 .{ }^{69}$ By committing to participate in the fair two years early it gave the Japanese time to ship thousands of packages to Philadelphia for the exhibition.

At the 1876 Philadelphia World's Fair, Japan built two structures. The first building was a small teahouse and bazaar which visitors could attend. ${ }^{70}$ The second structure housed the Japanese commission; the group responsible for preparing the Japanese exhibits. ${ }^{71}$ Construction of both structures drew the attention of the American people and crowds watched the construction process leading up to the Fair. The Japanese buildings were quite popular with the American public and were written about frequently in newspapers in the months preceding the Fair. ${ }^{72}$ Many were shocked at the methods employed by the Japanese workers, and one article described the process as "an ingenious puzzle which was being connected." ${ }^{13}$ This was because the structure was built to fit together without nails and, unlike structures in the United States, it was built on poles. ${ }^{74}$

At the 1876 Fair, Japan seemed to concentrate on the aesthetic qualities of Japanese arts and crafts. Such a focus differed from those of other nations that participated, which focused on

\footnotetext{
${ }^{68}$ Ibid.

${ }^{69}$ Clapp, 28.

${ }^{70}$ Ibid., 28.

${ }^{71}$ Ibid., 28.

${ }^{72}$ Ibid., 28.

${ }^{73}$ Ibid., 29.

${ }^{74}$ Ibid., 29.
} 
displaying industrialization and machine processes. The intricate details and time-intensive work of the Japanese art exhibits enthralled American visitors to the Fair.

The forcible opening to the West started a decades-long political evolution that brought Japan to the international stage. This period, known as the Meiji Restoration, unified Japan under a single governmental structure that would later participate at the Fair. A factor of the Restoration was modernizing the Japanese military as it moved away from a Samurai class toward the construction of a Westernized military. Japan used its military power to assert power over neighboring countries and downplayed this offensive when molding its appearance for the West. The evolution of Japan's growth gained recognition through their presentation at World's Fairs. The Fairs were an international platform that provided a place for countries to choose what image of their identity they would portray. Japan's construction of identity through the Fairs was most effective in 1904. The scale of the St. Louis World's Fair and the anthropological theme created an effective environment for Japan to separate themselves from other Asian countries and to build an image as a Westernized power in the East. 


\section{Chapter 3: Reception, Post-Structuralist, and Post-Colonial Theory}

The theory discussed in this chapter builds a foundation of literature that allows examination of Japan's interactions with the Ainu and the United States at the 1904 World's Fair. First, Reception theory is utilized to examine perceptions in guidebooks written primarily by western authors. This theory further places a focus on the conditions of access to art and how the preconceived environment influences the viewer experience and understanding. There is also a focus on the temporal nature of these interactions which is particularly important to the experiences at World's Fairs. Finally, the post-colonial theory is utilized to examine the relationship between the Ainu and the Japanese. This theory places a focus on the colonial aspects of the relationship with/oppression of the Ainu. These theories in addition to the guidebooks frame the examination of the 1904 World's Fair in this thesis.

\section{Reception Theory}

Early theorists such as Georg Wilhelm Friedrich Hegel (1770-1831) helped to lay the groundwork for the use of reception theory in the field of art history. Hegel's lecture on aesthetics (1818) is considered to be one of the most comprehensive early studies on art and how it is discussed and examined. ${ }^{75}$ Hegel believed that the interaction between the viewer and a work of art were the most important relationship to examine. This was especially important, given that during the eighteenth century there had been a call to disregard the viewer/beholder relationship as important. ${ }^{76}$ Hegel identifies two modes of existence for a work of art, these are a piece of work existing for itself or existing for us (the viewer). ${ }^{77}$

\footnotetext{
${ }^{75}$ Paul Redding, "Georg Wilhelm Friedrich Hegel," The Stanford Encyclopedia of Philosophy (Summer 2018 Edition), Edward N. Zalta (ed.), https://plato.stanford.edu/archives/sum2018/entries/hegel/.

${ }^{76}$ Ibid.

${ }^{77}$ Ibid.
} 
The existence of work 'for us' is broken down into three distinct phases by Hegel. ${ }^{78}$ The phases Hegel examines are Austere style, Ideal style, and Pleasing style. ${ }^{79}$ The Austere style was described as the work being closed to itself and to the viewer. ${ }^{80}$ The next phase was the Ideal style, where art was considered to have opened to a point that the recognition of the viewer's presence seemed like a "gift". ${ }^{81}$ The final phase was the Pleasing style, which was when art was no longer just for itself and had a greater connection to the outside world.$^{82}$

Aesthetic reception garnered attention in the 1960s and the 1970s when theorists such as Wolfgang Kemp focused on a contemporary conceptualization of the theory. ${ }^{83}$ There was a discussion about the need to pay attention to the conditions of access to an artwork. Most contemporary people viewing artwork are doing so in an institutionalized setting. Museums or other institutions create a pre-defined circumstance to the interactions between the art and beholder. Kemp describes it as the "prearranged interpretative spheres" 84 that are created in which interaction with art might occur. Kemp wrote a seminal work on reception theory, The Work of Art and Its Beholder: The Methodology of the Aesthetic of Reception (1998), with an examination of the relationship between art and the beholder. A key argument Kemp makes is that the beholder cannot be completely unbiased as the beholder will be influenced by his internal conditions such as the time one lives in, gender, personal history, etc. ${ }^{85}$ This is an important point to make when discussing the relationship between Japan and the West during the

\footnotetext{
${ }^{78}$ Ibid.

${ }^{79}$ Ibid.

${ }^{80}$ Ibid.

${ }^{81}$ Ibid.

82 Ibid.

${ }^{83}$ Peter Burke, "The History and Theory of Reception," Chapter within: Lloyd, Howell A. Reception of Bodin. Brill's Studies in Intellectual History, Volume 223, Brill, 2013.

${ }^{84}$ Wolfgang Kemp, "The Work of Art and Its Beholder: The Methodology of the Aesthetic of Reception," Subjects of Art History / Ed. by Mark A. Cheetham; Michael Ann Holly, 1998, 184.

${ }^{85}$ Ibid., 180.
} 
1904 World's Fair, because the opinions and perceptions of Japan were inescapably influenced by the preconceived notions and environment of the viewer, which in this case are Westerners.

It must be recognized that the interaction is temporal and can change based on the environment, surroundings, and time that the interaction occurs. ${ }^{86}$ Kemp suggests that "Creative misunderstanding does not simply occur; given specific historical circumstances, it is both a deliberate and a necessary attitude. ${ }^{\prime 87}$ An important part of the perception of the artist or piece of art is influenced by differences in cultural translation. ${ }^{88}$ This provides the precedence that while one is not part of a specific culture, one is still able to discuss that culture through the viewer/audiences' reception/-perception of the material.

Kemp separates reception theory into reception history and reception aesthetics. Reception history is divided into different contextual focuses, there is a work-specific procedure that "pursues migration and transformation of artistic formulas through different artistic contexts and historical periods." 89 This is usually more literary-based and can be difficult to apply to works of visual art. Reception history often traces the trends and common motifs in art and researches the reasons behind the decisions made historically..$^{90}$ Historical reception is often based on historical statements that can be difficult to interpret based on the original meaning and context. Interpreting historical statements are inherently influenced by the perspective of the reader and by time, thus it becomes impossible to guarantee that the meaning of a document stays unchanged by time. The modern construction of art history is generally centered around the

\footnotetext{
${ }^{86}$ Ibid., 181.

${ }^{87}$ Ibid., 181.

${ }^{88}$ Burke, "The History and Theory of Reception."

${ }^{89}$ Kemp, "The Work of Art and Its Beholder," 181.

${ }^{90}$ Ibid., 181-182.
} 
impact and importance of the institutionalization of art. Information about art and artists often comes from interactions with museums, exhibitions, and collectors.

Kemp sees a need to examine and acknowledge the "extrinsic conditions of access and intrinsic points of reception already in place." ${ }^{91}$ Due to institutional settings, the beholder will adhere to a set of standards when viewing and interacting with a work of art. To examine the reception of a work of art, Kemp argues the work must be placed back in its original setting to accurately examine the reception. The changes that occurs from the original setting to the current are also important factors of reception that should be examined. The sense of the relationship of the work of art through time is key to reception aesthetics.

When examining a work of art Kemp states that "if one says that $\mathrm{X}$ influenced $\mathrm{Y}$ it does seem that one is saying that $\mathrm{X}$ did something to $\mathrm{Y}$ rather than $\mathrm{Y}$ did something to $\mathrm{X}$.... If we think of $\mathrm{Y}$ rather than $\mathrm{X}$ as the agent, the vocabulary is richer and more attractively diversified: draw on, resort to, avail oneself of, appropriate from, have recourse to, adapt, misunderstand, refer to." 92 This viewpoint moves the burden of intention away from the creator and on to the receiver, by thinking about reception theory as the beholder/receiver of influence becoming an active participant instead of a passive recipient. The perspective of the receiver can change the way something is understood and interpreted. It is important to acknowledge this factor when examining a work of art and to understand that there is no such thing as impartial examination/reception.

Kemp discusses the interpretive element of aesthetic reception that sets it apart from other types of reception. "Reception aesthetics is prepared to read the appeals and signs that a

\footnotetext{
${ }^{91}$ Ibid., 184-185.

92 Burke, "The History and Theory of Reception," 23.
} 
work of art directs at its beholder. ${ }{ }^{93}$ When using aesthetic reception, it is important to always watch for an implicit beholder or if a piece of work was created for someone or something. Kemp breaks it down into three tasks that reception aesthetics undertakes. The first connects with historical reception and examines the sociohistorical context of a work. ${ }^{94}$ This can lead into the other two tasks which are to look for a purposeful aesthetic statement and to determine the ways in which the work connects with us (the viewers). ${ }^{95}$

Hans Robert Jauss also started working with reception theory in the late 1960s and continued through the 1980s and stated "literature and art only obtain a history that has the character of a process when the succession of works is mediated not only through the producing subject- through the interaction of author and public." ${ }^{96}$ Jauss is one of the most influential figures that contributed to aesthetic reception theory. He argued for the integration of history and aesthetic theory and made the argument that these are interdependent and that both are needed to develop a clear image of reception theory.

Peter Burke discusses a problem with reception theory in the 1990s, which is deciphering the differences between reception and intention. Often there is a disconnect of expectations between what was given and the perception of what was received versus what was actually received ${ }^{97}$ This is an important issue to assess for this thesis, which primarily examines guidebooks that are impacted by the bias of the writer, especially the distinct differences between Eastern and Western authors. While one country may present an aspect of their culture is a clear manner, this viewpoint is dependent on the assumption of their own inherent understanding of

\footnotetext{
${ }^{93}$ Kemp, "The Work of Art and Its Beholder," 183.

${ }^{94}$ Ibid., 183.

${ }^{95}$ Ibid., 183.

${ }^{96}$ Holub, Reception Theory, 57-58.

${ }^{97}$ Burke, "The History and Theory of Reception," 22.
} 
their culture. A lack of cross-cultural understanding is an intrinsic factor of interactions at World's Fairs.

\section{Poststructuralism}

Poststructuralism is another important part of the theoretical approach that is pertinent to the examination of the cultural discourse generated between Japan and the West. A key point is that poststructuralism argues that the study of underlying structures is subject to bias and misinterpretation due to the inability for culture and history to be separated from the study of structure. ${ }^{98}$ To study an object or structure accurately a study of both the actual object and the system of knowledge that led to its creation are necessary. Language is also an important part of creating the structure for examining an object. Chris Weedon describes language as "the place where actual and possible forms of social organization and their likely social and political consequences are defined and contested yet, it is also the place where our sense of ourselves, our subjectivity, is constructed." 99 An important theorist when discussing post-structuralism is Michel Foucault (1926-1984). Of importance to this paper is his theory on power and the relationship it has with knowledge as outlined in his book The History of Sexuality (1976). Foucault argued that:

Discourses are not once and for all subservient to power or raised up against it, any more than silences are. We must make allowance for the complex and unstable process whereby discourse can be both an instrument and an effect of power, but also a hindrance, a stumbling block, a point of resistance and a starting point for an opposing strategy. Discourse transmits and produces power; it reinforces it, but also undermines and exposes it, renders it fragile and makes it possible to thwart it. ${ }^{100}$

\footnotetext{
${ }^{98}$ Chris Weedon, Feminist Practice and Poststructuralist Theory, (Oxford, UK: B. Blackwell, 1987), 21. ${ }^{99}$ Ibid., 21.

${ }^{100}$ Michel Foucault, Excerpts from The History of Sexuality: Volume I: An Introduction, Natoli, Joseph P, Linda Hutcheon, and Rogers D. Spotswood Collection. A Postmodern Reader. Albany: State University of New York Press, 1993. 340.
} 
In this paper, Foucault's argument on power assists in informing the relationship between Japan and the United States. The United States, alongside other Western nations, sets the International discourse for power, creating the structures that propagated the idea that those of European decent are above all others.

\section{Post-Colonial Theory}

The final theoretical perspective pertinent to this paper to be discussed is Post-Colonial theory. Post-Colonial theory focuses on the oppression of a group perceived as "other" by a larger power. The theory historically focused on Western colonial powers and their relationship with their colonies, such as Great Britain and their former colonies in Africa or India. Postcolonial theory is pertinent when examining the relationship between the Japanese government and the marginalized Ainu people and how it impacted its exhibition at the 1904 World's Fair.

For the Japanese government, interactions with the Ainu became about removing their cultural identity, such as facial tattoos on women, and striving to eliminate the Ainu language and their independence. ${ }^{101}$ Japan took control of the Ainu lands and culture and sought to integrate them into Japanese society. In this case, Japan wanted to be viewed as the colonizer and wanted the Ainu to be seen as a primitive indigenous population that was subjugated.

Post-Colonial theory often examines how an oppressed/colonized population strives to maintain their own cultural identity. A goal of the theory is to examine the justification made by the colonizing power for taking control of a population, in some way. This generally involves perpetuating the idea that the oppressed are inferior. Perception of inferiority is used by the colonizer to justify stepping in and attempting to civilize a group, based on a set of standards the colonizers deem as civilized. Many of these ideals of Post-Colonial theory were first addressed

\footnotetext{
${ }^{101}$ Lars Krutak, “Tattooing Among Japan’s Ainu People,” Skin and Ink Magazine, November 27, 2012. 60-68.
} 
by Edward Said (1935-2003) in his book Orientalism, 1978. Said is often seen as the founding father of Post-Colonial theory and his theories are critical to its development.

Said's Orientalism brought the term into academic discourse when examining the patronizing tone that pervades the Western attitude toward Eastern culture. ${ }^{102}$ Said states that "the relationship between occident and orient is a relationship of power, of domination, of varying degrees of a complex hegemony."103 The post-colonial perspective focused on the selfperception by Western societies that they are civilized and superior to Eastern societies, which are considered uncivilized or less evolved. ${ }^{104}$ A qualification Said makes for examining the East is that "ideas, cultures, and histories cannot seriously be understood or studied without their force, or more precisely their configuration of power, also being studied." 105 The term Orientalism takes on different meanings depending on the field in which it is being discussed. It is important to understand how the term Orientalism has evolved. During the nineteenth century it particularly referred to the Middle East. Said redefined Orientalism as a patriarchal reference to South and East Asia as well as the Middle East. It is used by art historians when a Western artist portrays or depicts Eastern cultures. Said explained this as "the Orient was Orientalized not only because it was discovered to be Oriental in all those ways considered commonplace by an average Nineteen century European, but also because it could be that is, submitted to being made Oriental."106 Orientalizing the East was seen as a way for Westerners to appear as superior and developed in comparison to what they saw as undeveloped and inferior cultures.

\footnotetext{
${ }^{102}$ Edward W. Said, Orientalism, London: Routledge \& Kegan Paul Ltd,1978, 11.

${ }^{103}$ Ibid., 13.

${ }^{104}$ Ibid., 11.

105 Ibid., 13.

${ }^{106}$ Ibid., 14.
} 


\section{Chapter 4: The 1904 World's Fair}

The 1904 Fair in St. Louis was larger than all its predecessors in overall size, attendance, and exhibitions. Japan presented a well-planned and strategic arrangement of exhibits and balanced aesthetic imagery with industrial and mechanical advancement. While Japan had attended Fairs and exhibited before 1904, the St. Louis Fair presented an opportunity for Japan to set itself apart from other countries in Asia. Japan had a larger exhibition space than had been available during previous Fairs and took advantage of it by bringing more items to display which impressed many Westerners. Visitor accounts have presented impressions of Japan at the Fair. Japanese reception by Fair visitors was a resounding success and served to impress visitors and presented Japan with an opportunity to be acknowledged for their achievements and advancements. Even while being at war with Russia, Japan spent $\$ 880,000$ in 1904 , which after calculating the rate of inflation, is almost the equivalent of $\$ 25,000,000$ in 2019 . The overall setup of the Fair and Japanese participation frames the examination and analysis of photographs discussed in the next chapter. Japan's emphasis on visual elements provides an opportunity for closer examination of reception by Westerners. Photographs from the Fair are important to the discussion of the impact the Japanese exhibits had on the perception of Japan and can be examined through first-hand accounts from guidebooks.

The 1904 World's Fair in St. Louis was an especially effective and influential platform for the Japanese government. It was one of the first World's Fairs for which Japan had adequate time to fully prepare its exhibits and was represented by a unified Japanese government instead of individual factions or outside parties. The Japanese indigenous population, the Ainu, were brought to the Fair by the United States as part of the Anthropological exhibit. The United States requested permission from the Japanese government to put the Ainu on display at the Fair and 
the request was approved. ${ }^{107}$ The Fair organizers were attempting to showcase all the indigenous populations from around the world. ${ }^{108}$ The Ainu were a little-known group even among the Japanese. ${ }^{109}$ The Ainu would have been an effective tool for Japan to use to influence the perception of a hierarchy of advancement, that was a recognizable standard in the West. Japan accomplished this by separating itself from what was considered their indigenous population.

There were also many Geisha that Japan brought to the Fair; their job was to sing, dance, perform tea ceremonies, and work on the Pike in the Fair Japan exhibit. Geisha were often perceived as the physical embodiment of an idealized version of Japan, from the perspective of Westerners. This perception was likely based on their exposure to Japanese prints and paintings that often showcased the images of Geisha. They were also often viewed as living art and were a unique attribute that Japan capitalized on when attending World Fairs. Japan brought Geisha to each Fair they participated in previously, reinforcing the importance of the image created by Geisha. By strategically balancing an emphasis on aesthetic imagery and focusing on modernization. Japan strategically chose how to shape its identity and strove to influence reception by the United States and the West as a whole. The analysis in the following chapters is focused on the guidebooks and handbooks published around the period the Fair occurred. These books provide a basis for a theoretical discussion and are extensively discussed in the literature review.

The Meiji Restoration was an important influence on the development of Japan and the development of its identity at the 1904 Fair. ${ }^{110}$ The World's Fair of 1904 held in St. Louis,

\footnotetext{
${ }^{107}$ James W. Vanstone, "The Ainu Group at the Louisiana Purchase Exposition, 1904," Arctic Anthropology 30, no. 2, 1993, 78-80.

${ }^{108}$ Mizuta, "Fair Japan," 28.

${ }^{109}$ Ibid., 28.

${ }^{110}$ See W.G. Beasley, The Meiji Restoration. Stanford, Calif: Stanford University Press, 1972. for more information. In Japanese history, the Meiji Restoration is the political revolution in 1868 that brought about
} 
Missouri was known as the Louisiana Purchase Exposition, in commemoration of the purchase of the Louisiana Territory in 1803 , which almost doubled the size of the United States. ${ }^{111}$ It was originally planned as a centennial exhibition of the Louisiana Purchase for 1903, but was delayed until 1904 to allow more countries to participate and to complete construction. ${ }^{12}$ The Fair started on April $30^{\text {th }}$, with 187,793 people in attendance, breaking all previous Fair opening-day records. ${ }^{113}$ There were sixty-two countries that participated in the Fair, with exhibits spanning across one thousand two hundred and forty acres of the Forest Park area of St. Louis (Figure 9). ${ }^{114}$ The grounds consisted of nearly one-thousand buildings: fourteen Palaces, forty-five State buildings, forty foreign pavilions, concession structures, and permanent structures. ${ }^{115}$ The Fair concluded December $1^{\text {st }}$ of 1904 , after attracting around nineteen million visitors. ${ }^{116}$

At the 1904 Fair, Japan brought exhibits that were sophisticated and highlighted their aesthetic expertise and traditions. ${ }^{117}$ In Everett's The Book of the Fair, published in 1904, he noted that "the Japanese exhibit was the most extensive and there were examples in art and

the final demise of the Tokugawa shogunate (military government), thus ending the Edo (Tokugawa) period (1603-1867) and returned control of the country to direct imperial rule under Mutsuhito (the emperor Meiji). In a wider context, the Meiji Restoration of 1868 came to be identified with the subsequent era of major political, economic, and social change. The Meiji period (1868-1912) brought about the modernization and Westernization of Japan.

${ }^{111}$ H. Phillips Fletcher, The St. Louis Exhibition, 1904. London, B.T. Batsford, 1905, 2.

112 Mike Truax, The 1904 St. Louis World's Fair "100 Years of Memories," N.p. West County Marketing Group, LLC,2004, 2.

${ }^{113}$ Mark Bennitt, History of the Louisiana Purchase Exposition: comprising the history of the Louisiana territory, the story of the Louisiana purchase and a full account of the great exposition, embracing the participation of the states and nations of the world, and other events of the St. Louis World's Fair of 1904, Saint Louis: Universal Exposition Pub. Co., 1905, 127.

${ }^{114}$ Fletcher, The St. Louis Exhibition, 1904, 2.

${ }^{115}$ Major J. Lowenstein, Official guide to the Louisiana Purchase Exposition at the city of St. Louis, state of Missouri, April 30th to December 1st, 1904, by authority of the United States of America. St. Louis: The Official Guide Co., 1904, 11.

116 The 1904 World's Fair is one of the largest Fairs in acreage and exhibitions; only Expo 2010 in Shanghai, China was larger.

${ }^{117}$ Laura Kim, The influence of St. Louis 1904 World's Fair on Japonisme that appeared in periodicals, M.S. University of Missouri-Columbia, 2012. 
workmanship that bordered on the marvelous. It was by far the most unique exhibit of any foreign country, and one of the most interesting." 118 The Japanese government's exhibition space and buildings at the Fair and the final layout included over 80,000 pieces that came from 2000 individuals or businesses. $^{119}$

Mark Bennitt, the author of the guidebook History of the Louisiana purchase exposition: comprising the history of the Louisiana territory, the story of the Louisiana purchase and a full account of the great exposition, embracing the participation of the states and nations of the world, and other events of the St. Louis World's Fair of 1904 (1905) stated that "Japan spared neither effort nor expense to make the most comprehensive display of her products and resources ever sent to an exposition from an Oriental country." ${ }^{20}$ The space Japan had was significantly larger partially due to Russia withdrawing from sections of the Fair and Japan taking over some of the space. ${ }^{121}$ Everett observed that "although the war in the Orient caused Russia to withdraw its plans in regard to exhibition at the Louisiana Purchase Exposition, Japan was undaunted and the plans for its exhibit were carried on as though peace and serenity reigned in the Orient."122 The precision and organization that Japan employed to bring pieces to exhibit and prepare displays despite the ongoing conflict with Russia, had brought Japan high regard from the Fair organizers. ${ }^{123}$

The Japanese commissioners group (Figure 13) had been sent to the United States before the Fair began to secure exhibition space and a beautiful well-located place for the Japanese

\footnotetext{
${ }^{118}$ Marshall Everett, The book of the Fair: the greatest exposition the world has ever seen photographed and explained, a panorama of the St. Louis exposition, Philadelphia: P.W. Ziegler, 1904, 369.

${ }^{119} \mathrm{Kim}$, The influence of St. Louis.

${ }^{120}$ Bennitt, History of the Louisiana Purchase Exposition, 305.

${ }^{121}$ Mizuta, Fair Japan, 40.

122 Everett, The book of the Fair, 369.

${ }^{123}$ Final report of the Louisiana purchase exposition commission, Washington: Gov't Print Off, 1906, 220.
} 
Pavilion to be built. ${ }^{124}$ The commissioners were successful with Japanese exhibits placed in twelve departments at the Fair including: Education, Varied Industries, Manufactures, Liberal Arts, Fine Arts, Machinery, Electricity, Transportation, Agriculture, Forestry, Fish and Game, Mines and Metallurgy. ${ }^{125}$ In addition, Japan had its own pavilion and garden and the 'Fair Japan' concession on the Pike. In Bennitt's book the success of Japan's exhibits were described as having "had never so completely exploited her art and industries abroad before, nor had we, as a nation, any conception of the diversity of her art or the true genius and skills of her artists." 126 Everett declared that "No foreign country had a better representation at the Universal Exposition than Japan."127

An important change that occurred at the 1904 Fair was the classification of 'art' and what that entailed. ${ }^{128}$ Art was no longer separated into fine art and industrial art, meaning that metalwork, textiles, and other 'industrial art' was shown in the Fine Arts hall for the first time. ${ }^{129}$ Japan set up six galleries in the West Pavilion of the Fine Arts Palace (Figure 10). ${ }^{130}$ The Japanese galleries were filled with a variety of work including: paintings, drawings, metal, wood, lacquers, enamels, architecture, textiles, and sculpture (Figure 11). Even though there was a lot of variety amongst the pieces Japan brought, it was most recognized for cloisonné, enamel, and porcelain. ${ }^{131}$ The artisans of Japan had perfected their craft and were able to achieve levels of detail that stunned Western audiences. In Bennitt's compiled texts from the Fair, a section of The

\footnotetext{
${ }^{124}$ Hoshi, Handbook of Japan and Japanese Exhibits, 112.

125 Ibid., 115.

${ }^{126}$ Bennitt, History of the Louisiana Purchase Exposition, 285.

${ }^{127}$ Everett, The book of the Fair, 369.

${ }^{128}$ Louisiana Purchase Exposition Saint Louis, MO., and Koji Oi. Louisiana Purchase Exposition.

129 Ibid.

${ }^{130}$ Louisiana Purchase Exposition Saint Louis, MO. and Halsey C Ives, Official Catalogue of Exhibitors: Universal Exposition, St. Louis, U.S.A. 1904: Division of Exhibits. Department B, Art, Halsey C. Ives, Chief. Rev. Ed. ed. St. Louis, Mo.: Published for the Committee on Press and Publicity by the Official Catalogue, 1904.

${ }^{131}$ Louisiana Purchase Exposition Saint Louis, MO., and Koji Oi. Louisiana Purchase Exposition.
} 
History of the Fair noted that "From the Imperial School of Art came portraits and landscapes that illustrated well the innate artistic sense of the Japanese people and demonstrated, moreover, how well they were learning to handle European materials and methods." 132

The language in Bennitt's book is indicative of the Western mentality toward Japan. It presents the idea that Japanese artists would need to learn to handle the materials and methods employed in Europe, and assumes that they are inferior in comparison to the superior West. European materials and methods seem to be equated to learning an advanced skill in the text, referencing the racial bias that was deeply-rooted in the interactions between the East and West.

The Japanese government made the strategic decision to appeal to Western interest in Japanese artistry. ${ }^{133}$ While industrial art pieces were presented in the Fine Arts Palace, Japan still included many of these items in other departments. In the Department of Liberal Arts, Japan displayed photographs alongside photographic and printmaking innovations. ${ }^{134}$ The Japanese exhibit in the Department of Manufactures included Lacquered Ware, Porcelain, Earthenware, and Embroidery. ${ }^{135}$ In the Palace of Varied Industries, Japan took advantage of one of its larger exhibition spaces (Figure 12). The entrance to the 54,747 square foot space had a large gateway that was based on the Yomeimon Gate in Nikko. ${ }^{136}$

The Japanese garden was to the south of the Machinery Hall and housed the Japanese Pavilion, Office Building, the Formosa Mansion, Tea House, Observation Cottage and the Bazaar (Figure 14). ${ }^{137}$ The Japanese buildings had been built from supplies brought from Japan

\footnotetext{
${ }^{132}$ Bennitt, History of the Louisiana Purchase Exposition, 304.

${ }^{133} \mathrm{Kim}$, The influence of St. Louis 1904 World's Fair on Japonisme that appeared in periodicals.

${ }^{134}$ The exhibition of the Empire of Japan: official catalogue, St. Louis, MO.: International Exposition, 1904, 67.

135 Ibid., 77-81.

${ }^{136}$ Bennitt, History of the Louisiana Purchase Exposition, 305.

${ }^{137}$ Hoshi, Handbook of Japan and Japanese Exhibits, 114.
} 
and by Japanese artisans. ${ }^{138}$ Hoshi stated that "hills and waterfalls, the lakes and bridges over them, the lawns studded with bright flowers, are all harmonized in an artistic unit of landscape painting (Figure 15 and 16)." ${ }^{\prime 39}$ Many of the buildings were reproductions of famous and important buildings in Japan. For example, the Pavilion was modeled after the Shishinden Palace in Tokyo, which was the space where the emperor of Japan would meet with his ministers. ${ }^{140}$

The Pike at the St. Louis World's Fair was the entertainment section with large-scale themed attractions from around the world. It cost around ten million dollars to build, making it the most expensive entertainment section to be constructed for a World's Fair. ${ }^{141}$ The Pike did not close until eleven at night and was open later than the rest of the Fairgrounds. ${ }^{142}$ Marshall Everett described his visit to the Pike noting that:

You look up a broad paved highway, lined from beginning to end with bizarrelooking edifices, lined[...] with a dense crowd[...] You see and hear "a babble of strange tongues, the sound of unfamiliar instruments, the noise of many bands, the roar of animals from many climes, the voice of the barkers hawking the various entertainments[...]", the tramp of countless feet, and the indescribable din that only thousands (of people) hastily thrown together from all parts of the globe could make. ${ }^{143}$

John Brisben Walker described his trip to Japan's exhibit on the Pike in Cosmopolitan Magazine, September 1904, explaining that "Fair Japan looked very interesting, with its large entrance pagoda. The barker said it was a replica of the Temple of Nikko Gate, about 80 miles from Tokyo. The barker talked of acrobats, the Imperial Gardens of Mikado, and Geisha Girls. We even heard about the Spider Dance, where the dancers 'wove' strings all over the stage

\footnotetext{
${ }^{138}$ Lowenstein, Official guide to the Louisiana Purchase Exposition, 131.

${ }^{139}$ Hoshi, Handbook of Japan, 114.

${ }^{140}$ Lowenstein, Official guide to the Louisiana Purchase Exposition, 131.

${ }^{141}$ Truax, The 1904 St. Louis World's Fair "100 Years of Memories," 17.

142 Ibid., 17.

${ }^{143}$ Ibid., 18.
} 
(Figure 17 )." ${ }^{144}$ The main entrance to Fair Japan was an enormous gateway that towered above the Pike (Figure 18.) The gateway was a replica of the gateway in Nikko known as Yoney Mon. ${ }^{145}$ The Japanese Village admission cost twenty-five cents, and another fifty cents for the Japanese theater and additional attractions in the Fair Japan attraction on the Pike (Figure 19). ${ }^{146}$ After entering the attraction there was a street that mimicked the crowded shopping space in front of Asakusa Shrine in Tokyo. ${ }^{147}$ The street had a variety of stalls side by side down the road selling rugs, jewelry, paintings, fans, and candy. ${ }^{148}$

\footnotetext{
${ }^{144}$ Ibid., 22.

${ }^{145}$ Everett, The book of the Fair, 368.

${ }^{146}$ Ibid., 110.

${ }^{147}$ Ibid., 368.

${ }^{148}$ Ibid., 368.
} 


\section{Chapter 5: Japan's Aesthetic Portrayal and Reception at the Fair}

During the Meiji period, the Japanese began integrating Western culture into their own and adopting a Westernized view of modernization. ${ }^{149}$ A major part of influencing the perception of Japan was the creation of an iconic image that would be identifiably Japanese. ${ }^{150}$ The kimono and Geisha were popular elements in woodblock prints that had been exported to France and other parts of the West during the Nineteenth century. ${ }^{151}$ The style of clothing was so different from what was typically worn in France that it became instantly recognizable.

\section{Geisha and the Kimono}

An influential part of the image that Japan fashioned for itself at the World's Fair revolved around the kimono. During the Meiji period the cost and availability of Western attire made it appealing to the people of Japan. Men in Japan began adopting Western suits and short haircuts (Figure 12), which were a significant change from the traditional kimono and long hair. ${ }^{152}$ While men freely adopted new Western attire, women were actively discouraged from wearing Western styles. In Japan, women felt strong societal pressure to maintain roles that had been traditionally assigned to women, and as such, felt inclined to wear more traditional clothing. This trend led to the appearance of Japanese women being used as a symbol of traditional culture in Japan, through the traditional garbs that they wore.

The visual elements of the kimono were an inspiration to a multitude of fields in the West, such as clothing, design, and painting. Painters such as James McNeil Whistler (18341903) portrayed women in kimonos (Figure 20). Kimono-inspired garments became popular as

\footnotetext{
149 Ibid., 354.

150 Ibid., 356.

151 Ibid., 356.

152 O. Goldstein-Gidoni, "Kimono and the Construction of Gendered and Cultural Identities," Ethnology 38 , $1999,352$.
} 
evening wear for women when they were lounging around their home. While the kimono was spread to Western culture, it was still taboo to wear something like a kimono in public. Though kimonos were not adopted in the West, the richly patterned fabrics that made up kimonos were incredibly popular design elements for clothing and furniture. ${ }^{153}$ The kimono was also seen at the World's Fairs. Japanese women who worked at the Japanese Pavilion and at Fair Japan on the Pike were always dressed in elaborately detailed kimonos. This projected a beautiful and delicate image of Japan and its culture, which was what Japan intended to accomplish.

For many in the West, the only image of Japan they had was of Japanese women and the Geisha girls. ${ }^{154}$ Before World War II there were around 80,000 Geisha in Japan. A common misconception in the West about traditional Geisha is that they were glorified prostitutes. It was after World War II during the American occupation of Japan that the misconception about Geisha arose. ${ }^{155}$ During the occupation, prostitutes would call themselves Geisha girls to attract the attention of American military personal stationed in Japan. ${ }^{156}$ However, there were important distinctions in appearance that separated a Geisha and prostitute. Perhaps the easiest to spot is that a Geisha's obi is tied in the back while a prostitute would tie hers in the front. ${ }^{157}$ Geisha would require assistance to undress and remove the obi while prostitutes kept it in the front so that they would be able to change it themselves. Geisha were not prostitutes, but were artists, entertainers, and hostesses. To perform these multitude of jobs, they trained extensively for years, mastering their craft.

\footnotetext{
${ }^{153} \mathrm{Kim}$, The influence of St. Louis, 38.

${ }^{154}$ Ibid., 29.

155 Ibid., 29.

${ }^{156}$ Ibid., 29.

${ }^{157}$ Eliza Knight, "The History and Culture of Geisha," August 12, 2008.

http://www.historyundressed.com/2008/08/history-and-culture-of-japanese-geisha.html
} 
Japan sent Geisha to multiple World's Fairs and put them on display, which fascinated visitors, many of whom would have only seen a Geisha in a print or painting. Dozens of Geisha in full costume would walk the grounds and interact with visitors at the Fair, acting as envoys for Japan and drawing attention wherever they went. Lafcadio Hearn commented that:

For it has well been said that the most wonderful aesthetic products of Japan are not its ivories, nor its bronzes, nor its porcelains, nor its swords, nor any of its marvels in metal or lacquer - but its women. Accepting as true the statement that woman everywhere is what man has made her, we might say that this statement is more true of the Japanese woman than any other. Of course, it required thousands and thousands of years to make her; but the [feudal] period of which I am speaking beheld the work completed and perfected. ${ }^{158}$

This perspective was held by many in the West, which seemed to point out the objectification of the women of Japan and of Japan itself. Makoto Ueda comments, "In equating women with precious objects, Hearn was restating the popular myth about Japanese women prevalent in the West during the second half of the nineteenth century." ${ }^{159}$ Mizuta referred back to Hearn's comment and compared the objectification of Japanese women to being classified alongside ceramics and porcelain. ${ }^{160}$ They were allegorical representations of Japan and many in the West did not think of them as people.

In the images of Japanese Ladies and Children (Figure 21) and the Geisha girls (Figure 13) in Fair Japan from William Rau's The greatest of expositions completely illustrated there is the element of what Hearn and Ueda were discussing. The photograph of the Geisha (Figure 22) was a strategically posed image, in the Japanese garden, at the Fair. The caption discussed the dancing, singing and the spider-dance that the Geisha perform. ${ }^{161}$ Rau's book described the performances as "pervaded with the charm of Japanese young women, who flit about everywhere

\footnotetext{
${ }^{158}$ Mizuta, "Fair Japan,” 30.

${ }^{159}$ Ibid., 31.

${ }^{160}$ Ibid., 30.

${ }^{161}$ Ibid., 274.
} 
in the gardens and bazaars, demure and Fair (Figures 23 and 24)."162 Through this, we can perceive a distinct air of superiority on the part of the West, juxtaposed with the perception of the East as fragile, weak, and inferior.

The captions on both images are indicative of the objectification of Japanese women. Part of the caption on the photograph of the Japanese ladies and children states "Surely nothing could be more fascinating than one of the exquisite little morsels of femininity, clad in her graceful kimono and sash, her glossy black hair puffed back from her low brow." "163 The description juxtaposes the quote with a discussion on how the features of the Japanese have become familiar and unexciting and that seeing groups of them in cities in the United States no longer elicited the same reaction. The author of the discussion seemed disappointed that the Japanese have been adopting the American style of dress. ${ }^{164}$ While from the Western perspective it may have seemed odd or unfortunate that the Japanese assimilated the American way of dressing, there is a clear commentary on the inherent culture of Japan. By the end of the discussion the author is dissatisfied that the Geisha that were at the Fair wore traditional Japanese dress. ${ }^{165}$

\section{Tea Ceremonies and Japanese Culture}

The photograph of two women performing a tea ceremony from the St. Louis World's Fair (Figure 25), provides an opportunity for an in-depth look into the importance of traditional art forms in Japan and the role in its self-representation at the Fair. The relationship between the tea ceremony and the culture of Japan are closely intertwined; suggesting that the women in the photograph appear as physical vessels of cultural heritage and the history of Japan. The photograph also subliminally highlights the importance of Buddhism and Taoism to the

\footnotetext{
162 Ibid., 274.

${ }^{163}$ Rau., The greatest of expositions completely illustrated, 269.

${ }^{164}$ Ibid., 269.

${ }^{165}$ Ibid., 269.
} 
development of Japan and the way that the Japanese display their culture and beliefs. A Japanese tea ceremony is rich with subtle meaning and cultural importance and is highlighted in the photographs. Okakura Kakuzo discusses the inability of a Westerner to truly understand the significance of Teaism (the art of tea) stating that "those who cannot feel the littleness of great things in themselves are apt to overlook the greatness of little things in others. The average Westerner, in his sleek complacency, will see in the tea ceremony but another instance of the thousand and one oddities which constitute the quaintness and childishness of the East to him."166

The position of the women, the patterns on their clothes, and the way one holds the chasen (tea whisk that is hand-carved from a single piece of bamboo) to mix the tea, are all indicators of the significance of culture and tradition to the Japanese. The woman in the photograph has her hands poised and firmly committed to her task with the confidence that comes with intensive training. In the photograph, one of the women is shown whisking the tea with her right hand and her left hand is placed so that the tips of her fingers were on the edge of the bowl. She has her hands placed so that the bowl is stable and cannot tip but she does not wrap her hand around it. It is a subtle reminder of the respect that the Japanese have for tea ceremony and that it is a performance. Every movement of the tea preparation is executed with precision and grace, almost as if it is a choreographed dance. The photograph seems to portray the precision and confidence that the tea ceremony host exudes.

The photograph also provides a look into the situations that visitors to the Fair would have experienced. These performances would have been a part of shaping American perception of Japan. These were examples of what Kemp described as "prearranged interpretative spheres"

\footnotetext{
166 Okakura Kakuzo, The Book of Tea, New York: Duffield \& Co., 1906, 6.
} 
which are considered institutionalized settings that have preset conditions, that influence how the art is perceived. ${ }^{167}$ With these prearranged circumstances in mind, one can examine the visual elements of the photographs for their cultural significance and as an influential tool at the Fair. These prearranged circumstances created a temporal interaction between the art (the tea ceremony) and the audience. The interactions were always variable due to the time, environment or surroundings changing from one performance to the next.

Teaism is deeply rooted in Taoism and religious developments in Japan. ${ }^{168}$ Okakura Kakuzo stated that "the whole idea of Teaism is a result of the Zen conception of greatness in the smallest incidents of life. A tea ceremony is the preparation (called Chanoyu) and the presentation generally of Matcha, which is a type of powdered green tea, the preparation is called chanoyu. ${ }^{169}$ Matcha is a bitter green tea that is traditionally served with small sweets to offset the bitterness of the tea.

Kakuzo also discussed the influence that Teasim had on home designs, costumes, cuisine, porcelain, lacquer ware, painting, and literature in his text The Book of Tea which was published two years after the Fair. ${ }^{170}$ He emphasized in his writings that the impact of Teaism on Japan is something that "no student of Japanese culture can ignore." ${ }^{171}$ He further explained that the "beverage grew to be an excuse for the worship of purity and refinement, a sacred function at which the host and guest joined to produce for the occasion the utmost beatitude of the mundane." 172 At the Fair there were two tea house spaces and there were other buildings that

\footnotetext{
${ }^{167}$ Kemp, "The Work of Art and Its Beholder," 184.

${ }^{168}$ Kakuzo, The Book of Tea, 44.

${ }^{169}$ Selena Lai, Sōshitsu Sen, XY, Karen Tiegel, Freeman Spogli Institute for International Studies, and Stanford Program on International and Cross-Cultural Education, Tea and the Japanese Tradition of Chanoyu, Stanford, CA: Stanford Program on International and Cross-Cultural Education (SPICE), 2005, 111.

${ }^{170}$ Kakuzo, The Book of Tea, 5.

${ }^{171}$ Ibid., 5.

172 Ibid., 43.
} 
displayed different teas, products, and the process of tea ceremony. ${ }^{173}$ These tea ceremonies were attended by everyday Fairgoers, but were also attended by influential upper-class Westerners in charge of the Fair. Tea was a recognizably important part of Japanese culture and was an important product produced in Japan. The tea ceremony photographs from the Fair have extensive cultural background layered in them. The images provide an opportunity for a discussion of the interaction between the Geisha in the Japanese exhibits and Americans attending the Fair.

Each object in the tea ceremony generally has an important historical significance. The tea bowls are known as "chawan" (a bowl used for preparing and drinking tea in East Asia) and vary based on the consistency of the tea. The type of bowl is closely tied to the season and weather. When the weather is cold the bowl is deep and narrow to help the tea to stay warm and insulated. During the summer months the bowl that is used is wide and shallow to allow the tea to cool quickly. The bowl in the photograph (Figure 25) is deep and narrow around the top, which allows the tea to stay warm, indicating it might be from a cooler month during the Fair, likely November, or December. There appears to be respect for the importance of the implements used in the tea ceremony by the Geisha performing and, in the photograph (Figure 25), the respect can be observed in the way the women handle the tools while preparing the tea. In the article, Making Tea in Place: Experiences of Women Engaged in a Japanese Tea Ceremony by M. Sakuae and Reid D, a Japanese interviewer describing the tea ceremony stated:

The flow of performances is very beautiful [....] I think a tea ceremony has [a] long history and gets sophisticated [....] My teacher's temae is beautiful [....] the position of the tea implements is beautiful [....] The beginning shape is the same as the ending shape $[\ldots . .$.$] When my teacher makes tea [. .$.$] the way to make tea and wipe a$

${ }^{173}$ Lowenstein, Official guide to the Louisiana Purchase Exposition, 131. 
tea bowl $[\ldots .$.$] when she wipes it, the motion of her hands is smooth and we do see$ the bowl wobbling. I am impressed with that. ${ }^{174}$

The performance is never the same, it changes based on the guests, season, time of day, location, and many other factors.

The most well-respected historical figure in the history of tea ceremonies is Sen no Rikyu (1522-1591) ${ }^{175}$ and he is best known for following the concept of ichi-go and ichi-e (translated, the concept means 'one meeting, one time.)' ${ }^{176}$ These concepts placed an emphasis on the importance and value in every meeting of people and that those experiences can never be recreated. When entering a tea ceremony, it is customary for the host and the guest to sit in seiza (traditional way of sitting in Japan) and bow to each other.

The second tea ceremony photograph (Figure 26) shows four guests seated on small cushions in the formal Japanese manner, known as seiza, and is another facet of respect in Japanese culture. The Geisha in each of the photographs from the tea ceremony are also shown to be seated in seiza. When assuming seiza, the person kneels with their buttocks placed on their feet. The tops of their feet are placed flat on the ground. The person's kimono is then tucked under the sides of the legs so that the sides are neatly folded. Hands are then placed flat on the lap and the back is kept straight. While common in Japan, it can often be difficult for foreigners who are unaccustomed to being seated in this fashion. ${ }^{177}$ The formal manner of sitting was developed with the intention of using it when seated on tatami mats. In the photograph the floor of the tea house is clearly tatami mat, the two Geishas are seated on the mats, which could

\footnotetext{
${ }^{174}$ M. Sakuae and Reid D, "Making Tea in Place: Experiences of Women Engaged in a Japanese Tea Ceremony," Journal of Occupational Science 19, no. 3,2012, 288-289.

175 Willmann, "The Japanese Tea Ceremony,"

${ }^{176}$ Maikoya, "The Japanese Tea Ceremony Explained."

177 John Spacey, Seiza: Crippling Pain for Gaijin, Japan Talk, September 16, 2015 , https://www.japan-talk.com/jt/new/seiza, (accessed July 19², 2019).
} 
alleviate some of the strain related to sitting in seiza, for someone whose body is familiar with the position. The guests partaking in the ceremony (Figure 26) are seated on small cushions to the side of the room, likely to relieve the strain on their legs from being seated in seiza for a prolonged amount of time.

An important aspect of tea ceremonies are the philosophies of wabi and sabi; these terms refer to the transformative nature of the tea ceremony experience. ${ }^{178}$ Sabi is meant to represent the materialistic and external portion of life. The philosophy represents acceptance of oneself for their internal importance and to make the first step toward an enlightened state. Sabi was meant to reinforce the importance of the present and of the self. ${ }^{179}$ Wabi is the opposite of sabi and represents the internal and spiritual aspects of human life. ${ }^{180}$ The principle is characterized by a sense of restraint and humility within a person. "Together, wabi-sabi usually refer to beauty in simplicity. "Elegant simplicity" is present in all aspects of the tea ceremony." 181 The principles and philosophies of tea ceremony are reflective of the Japanese mind-set and temperament.

Kakuzo wrote extensively on the history and development of tea and the changing environment of Japan after opening to the West. He attended the St. Louis World's Fair and gave a presentation called "Modern Problems in Painting," which discussed the connections between art and war and examined how Japan used art as a form of cultural defense. ${ }^{182}$ Kakuzo commented on art as a form of warfare in The Book of Tea, stating that "he was wont [sic] to regard Japan as barbarous while she indulged in the gentle arts of peace: he calls her civilized since she began to commit wholesale slaughter on Manchurian battlefields." ${ }^{83}$ The 'he' implied

\footnotetext{
178 Ibid.

${ }^{179}$ Ibid.

${ }^{180}$ Ibid.

${ }^{181}$ Ibid.

182 Mizuta, "Fair Japan,” 29.

${ }^{183}$ Kakuzo, The Book of Tea, 7.
} 
in the quote seems to represents the West as a whole or specifically the United States. Kakuzo's idea was that Western countries would be swayed by the idyllic image of Japan that they created for themselves and ignored or even approved of the brutality of war with the other countries of Asia. The tea ceremony photograph is an effective example of what Kakuzo describes as idyllic imagery. The two women were seated in an intricately decorated tea house in traditional Japanese kimonos preparing tea for Westerners.

The second photograph from the tea ceremony (Figure 26) has a wider camera angle and includes more of the physical space as well as a small group of people partaking of the ceremony. The two photographs appear to be from the same tea ceremony performance. The Geisha performing the tea ceremony appear to be the same in both images and their kimono patterns are also the same. Based on my examination of the photographers these two images seem to provide different viewpoints of the same event, but the context feels different based on the perspectives. While in the first photograph the focus is on the two Geisha preparing tea, the second image places focus on the female seated in the central part of the image. The woman in the photograph was Mrs. Daniel Manning, the President of the Board of Lady Managers of the World's Fair. ${ }^{184}$ It is likely, given her stature, that the other people with her were important figures as well, even though they are not identified in the photograph description by name.

The guests are seated to the side instead of facing the Geisha preparing tea because after finishing the tea preparation it is possible that the Geisha would have relocated to face the guests and play music. It is possible that the image of two Geisha playing a Shamisen and Koto (Figure 27) was taken from the side of the room that is not visible in the tea ceremony images, Geisha are traditionally taught to play both instruments. The Shamisen looks like a small guitar and the

\footnotetext{
${ }^{184} \mathrm{Rau}$, The greatest of expositions completely illustrated, 258.
} 
Koto, the national instrument of Japan, is a large piece of wood that is laid flat and has strings held on a bridge like a guitar. The photograph of the Geisha with the instruments seems to be the same women from the previous images, but possibly on a different day, since their kimonos are not of the same patterned fabric.

\section{World's Fair Guidebooks and Western Bias}

It is difficult to determine in the images from the Fair if the women would have been Japanese women or specifically Geisha preparing and serving the tea. The guidebooks had conflicting viewpoints on who was and was not a Geisha. While Geisha were specially trained in the art of tea ceremony, an official guidebook from the Fair written by Marshall Everett discussed the Geisha as being the performers who were seen singing and dancing while the "normal" Japanese young women would serve tea. ${ }^{185}$ In contrast to Everett, Hajime Hoshi, who wrote a Fair handbook for Japan and the Japanese exhibits, described fifteen Geisha working in the tea house and makes no mention of "normal" Japanese young women. ${ }^{186}$

The idea of what constitutes the difference between Geisha and a Western idea of Japanese women is reflected in the different perspectives presented by Everett and Hoshi. Everett displays a clear Western bias and insufficient understanding about the different aspects of Geisha. There was not a divide between the women singing and dancing, and the women serving tea. Japanese culture sees all of these activities as performances and well-within standard practices for Geisha. This is an example of Kemp's reception theory discussion that a beholder becomes an active participant.

Everett was exposed to different aspects of Geisha and their varied responsibilities that were beyond the common perception. He views Geisha as women with painted faces dressed in

\footnotetext{
${ }^{185}$ Everett, The book of the Fair, 368.

${ }^{186}$ Hoshi, Handbook of Japan, 125.
} 
what a Westerner would see as a "costume." When presented with Geisha that do not fit his preconceived ideas, he assumes they are not Geisha. This misconception is then further perpetuated through his guidebook. This lack of clarity between Japanese and Western Guidebooks from the Fair is an effective point to examine the application of reception theory to better understand prevailing perspectives and misconceptions for this study.

Based on an examination of Hoshi's statements about the Japanese exhibits it is likely that the women working in the tea house were Geisha. Hoshi would have had more direct insight in his handbook because of his Japanese heritage and he was specifically focused on and writing about the Japanese exhibits. Unlike Hoshi, Everett's guidebook covered the entirety of the Fair from a Westerner's perspective and only dedicated a couple of pages to the Japanese exhibits and their presence at the Fair.

In the Western official guidebooks written about the Fair there is still an inherent amount of bias. It is likely that writers from the United States would have seen the Geisha who were dancing and singing, dressed in what they perceived as costumes, and presumed that the women that were not wearing "costumes" were not Geisha. The assumption would have been from a lack of knowledge or understanding of Japanese culture. Someone who is Japanese, would probably know that Geisha do not paint their faces all the time and that every facet of a Geisha's appearance is specific to different occasions or situations.

The accounts from the Fair had varied information on the Geisha who attended and there were clear differences in understanding between Japanese and United States writers. The perception of Geisha was a cultural misunderstanding that provides an example of an important factor of reception theory that Kemp discusses: the need to be aware of the internal conditions 
that may influence the beholder. ${ }^{187}$ Kemp discusses that when an object is removed from its original setting, it becomes difficult to understanding the meaning. ${ }^{188}$ The Western understanding of Japan by 1904 was still heavily based on a very limited exposure to art and cultural items. The interaction of Westerners with Japanese art and culture were removed from the intended context in Japan and experienced in a Western setting. It is as if some of the overall picture is covered, which leaves viewers to develop inaccurate or out-of-context viewpoints.

Burke also discusses the disconnect of expectations, that is, between the intention of something and the perception. ${ }^{189}$ This highlights the concept in reception theory that what is presented is not necessarily what is received. Along with this idea of presentation versus reception is the examination of the western understanding of the intricacies of tea ceremony and the importance the Japanese have placed on every facet of the performance.

The portrayal of Japanese women at the Fair set the stage to convey the acceptance by Westerners of the idea that the Japanese were gentle and refined. By this time, it appeared that Japan had successfully created a dual identity. One side of their identity, that was being primarily portrayed to the West was the quaint, artistic, and civilized nation. Japan's aesthetic decisions were an important part of the overall perception of the country. By focusing on displaying Geisha and experiential performances, Japan was able to develop the image that they wanted to portray to the United States. This was a dual image that Kakuzo discussed at the Fair, Japan as modern and militarized juxtaposed with the Western idea of the feminine, gentle and refined Japanese. Many of the comments discussed in this paper from the Fair by Westerners showcase amazement at the aesthetic imagery and skilled artisans Japan presented. There was an

\footnotetext{
${ }^{187}$ Kemp, "The Work of Art and Its Beholder," 181.

188 Ibid., 184-185.

${ }^{189}$ Burke, "The History and Theory of Reception," 22.
} 
subliminal appreciation for Japan's ability to be at war with Russia while also dedicating a large amount of time and money to the Fair. The 1904 Fair was an opportunity for Japan to be recognized for its growth on the international stage. Part of this recognition also came from the display of the Ainu. The Ainu were presented as an indigenous population that Japan had conquered. While Japan did not make the choice to bring the Ainu to the Fair, they became part of the perception of Japan. Japan used the Ainu as a counterpoint to its presentation of a modernized and artistic country. The Ainu were viewed as an indigenous group that had been subjugated by the Japanese. 


\section{Chapter 6: Japan, The Living Anthropological Exhibits, and the Ainu}

An aspect of the St. Louis World's Fair was also the 'living anthropological exhibits.' 190 The president of the St. Louis Fair was quoted in Carol Ann Christ's article the Sole Guardians of the Art Inheritance of Asia that the goal of Anthropological displays was for: "The exhibit of every country and of every people, classified in a manner unequaled for clear and competitive comparison,[...] testified to the advancement of civilization. ${ }^{191}$ The theme was an opportunity for W.J. McGee (1853-1912) the Chair of the Department of Anthropology for the Fair, to advance racist ideas through the influential stage of the World's Fair. ${ }^{192}$ Nancy J. Parezo and Don D. Fowler suggest that McGee's “need to popularize and legitimize anthropology had a lasting effect on how the public viewed Native people for years following the Louisiana Purchase Exhibition and after anthropology had changed its theoretical paradigm." ${ }^{193}$ McGee's objective was to 'prove' his "ideas about development of human institutions" and he strove to find "cultures uncontaminated by outside influence ("primitive" in the sense of the “original”)."194 Contemporary anthropologists described McGee's approach as "a strong speculative technique, bold in search of unifying hypothesis, but sometimes slender in supporting data."195

McGee was confused by the Ainu, describing them as an "Ethnological puzzle."196 The shocking thing about the Ainu for Westerners and for McGee was that they were viewed as being a white race that had been dominated by the Japanese. ${ }^{197}$ For Westerners with similar

\footnotetext{
${ }^{190}$ Kim, The Influence of St. Louis.

${ }^{191}$ Christ, "the Sole Guardians of the Art Inheritance of Asia."

192 Nancy J. Parezo and Don D. Fowler, "Anthropology Goes to the Fair: The 1904 Louisiana Purchase Exposition," Critical Studies in the History of Anthropology, Lincoln: University of Nebraska Press, 2007, 33. ${ }^{193}$ Ibid., 35.

194 Ibid., 39.

195 Ibid., 47.

${ }^{196}$ Mizuta, "Fair Japan,” 39.

${ }^{197}$ Ibid., 39.
} 
ethnographic viewpoints as McGee, it challenged their assumption on evolution. The interest in the Ainu, provided the Japanese a point that could be used to position themselves as a more Westernized/civilized country in the eyes of the United States. Japan was presented with the unique opportunity; as a non-western country, to have its indigenous population, displayed at the Fair. Fair organizers were interested in the Ainu and asked permission from the Japanese government to display them at the Fair. Japan consented and took advantage of the situation to attempt to influence the perception of Japan as a colonizing power.

History of the Ainu

The Ainu are an aboriginal group that primarily lives in Hokkaido and the islands north of Hokkaido. ${ }^{198}$ These islands were often disputed between Japan and Russia during the nineteenth and early twentieth century. ${ }^{199}$ The Ainu are "particularly noted for their hirsute bodies and are frequently referred to as the 'Hairy Ainu' in early literature."200 These descriptions were clearly meant to build on stereotypes to create a strong separation between the Ainu and the Japanese. It also served to label the Ainu as inferior to what was categorized as “civilized" at the time. ${ }^{201}$ The island of Sakhalin, which was also inhabited by the Ainu, was jointly possessed by Russia and Japan until $1945 .{ }^{202}$ The Ainu faced a similar situation to colonized countries with their culture and way of life being infringed upon and oppressed by the Japanese. Like many Western countries' handling of indigenous populations, Japan attempted to control and regulate the Ainu into being more Japanese. Over time, the Ainu were pushed into a smaller and smaller sections of the country. ${ }^{203}$ This was a similar type of treatment of an

\footnotetext{
198 Vanstone, "The Ainu Group at the Louisiana Purchase Exposition, 1904," 78.

${ }^{199}$ Ibid., 78.

${ }^{200}$ Ibid., 78.

${ }^{201}$ Ibid., 78.

202 Mizuta, "Fair Japan,” 39.

${ }^{203}$ Krutak, Tattooing Among Japan's Ainu People, 60-68.
} 
indigenous group, that the United States had practiced since landing in North America and could have benefited Japan, by making them appear as a stronger civilized power and like other colonial powers.

In the Ainu culture, tattoos were an important part of their belief structures. Women were the ones who had tattoos and they were for protection from evil spirits attempting to enter their bodies. ${ }^{204}$ Girls around the age of six or seven would have a small dot tattooed above their lips. ${ }^{205}$ The small dot would serve as the central spot for the tattooist to work from when girls would reach maturity. ${ }^{206}$ At that point the tattoo would be extended to the ends of the mouth and curve slightly upward toward the ears (Figure 42). These tattoos would signal that the woman was ready for marriage and the Ainu believed that the tattoos assured women a place in the afterlife with her ancestors. ${ }^{207}$ When Starr was in Hokkaido choosing Ainu people to come to the Fair, he explained that:

It is not done by pricking with points as Japanese tattooing is, but by cutting with a knife. Soot from the bottom of the kettle is rubbed into the cut line and a decoction ${ }^{208}$ of ash bark is washed on to fix the color, which as already stated, is a blue-green. The tattooing is gradually developed, until, when the girl is ready for marriage, the whole, great, moustache-like mark is fully done. It completely surrounds the mouth, covering both upper and lower lip, and even extends onto the mucous membrane surface. ${ }^{209}$

As early as 1799 , the Ezo Shogunate ${ }^{210}$ attempted to ban tattoos. They stated that "regarding the rumored tattoos, those already done cannot be helped, but those still unborn are

\footnotetext{
${ }^{204}$ Krutak, Tattooing Among Japan's Ainu People, 60-68.

${ }^{205}$ Ibid., 60-68.

${ }^{206}$ Ibid.

${ }^{207}$ Ibid.

${ }^{208}$ Decoction is the liquor resulting from concentrating the essence of a substance by heating or boiling, especially a medicinal preparation made from a plant.

${ }^{209}$ Starr, The Ainu Group at the Saint Louis Exposition, 39.

${ }^{210}$ Ezo is the former name of Hokkaido, the northern most island of Japan. The shogunate was the military dictator of Japan during the period from 1185 to 1868. In most of this period, the shōguns were the de facto rulers of the country, although nominally they were appointed by the Emperor as a ceremonial formality.
} 
prohibited from being tattooed." ${ }^{211}$ Later in 1871, the Hokkaido Development Mission stated that "those born after this day are strictly prohibited from being tattooed." 212 The Mission explained that their reasoning was that the tattoo process was cruel and went against the teachings of

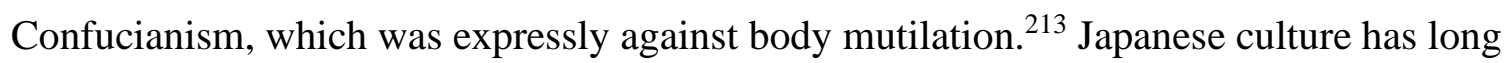
associated tattoos with criminals, which increased the discrimination against the people of the Ainu with tattoos. Ainu would often evade the tattoo laws because of the importance of tattoos to their religious and cultural beliefs. ${ }^{214}$

\section{Bringing the Ainu to the Fair}

Dr. Fredrick Starr (1858-1933), an anthropology professor at the University of Chicago, was assigned to go to Japan and bring a group of Ainu to St. Louis for the Fair. ${ }^{215}$ Starr speculated in his book, The Ainu Group at the St. Louis Exposition, that "The Ainu are an example of a white race, which was broken and submerged by a great flood of active yellow Asiatics [.... If the Japanese successfully subjugated the white race once in the form of the Ainu then why should it not be capable of winning the Russo-Japanese War against Russia, a less hairy opponent." 216 This suggests that westerners saw the subjugation of the Ainu as a model for Japan's ability to beat Russia.

Starr traveled to Japan at the behest of McGee to find Ainu willing to be on display at the Fair with a letter of introduction from the 1904 World's Fair President, David R. Francis. ${ }^{217}$ Starr took the letter to the Commissioner General of the Imperial Japanese Commission for the

\footnotetext{
${ }^{211}$ Krutak, Tattooing Among Japan's Ainu People, 60-68.

${ }^{212}$ Ibid., 60-68.

${ }^{213}$ Ibid.

${ }^{214}$ Ibid., 60-68.

${ }^{215}$ Eric Breitbart, A World on Display: Photographs from the St. Louis World's Fair, 1904, 1st ed. Albuquerque: University of New Mexico Press, 1997, 63.

216 Mizuta, "Fair Japan," 39.

217 Vanstone, "The Ainu Group at the Louisiana Purchase Exposition, 1904," 79.
} 
Louisiana Purchase Exposition so that he would have assistance upon arrival in Japan. ${ }^{218}$ Mark Bennitt described the Ainu in his handbook on the Fair, "they are notable for small stature, light color skin and abundant hair and beard. Indeed, they are frequently spoken of as the 'Hairy Ainu' (Figure 41). The men show little trace of Mongolian or Malayan affinity, more nearly approaching the Caucasian type and suggesting relationship with the Cossacks of Siberia rather than any other Asiatic people." ${ }^{219}$ The confusing origins of the Ainu were fascinating to a Western audience and this presented an opportunity for Japan to manipulate its portrayal at the Fair. ${ }^{220}$ The portrayal of the Ainu was different from the way Japan presented itself in the rest of the Fair. James Vanstone discussed the Ainu stating that:

The Ainu were believed by McGee, Starr, and others to be the "aborigines of the Japanese Empire," and McGee was certain that they "magnified the racial characteristics that underlay Japanese progress." Furthermore, McGee believed the Ainu illustrated in their occupations and handiwork some of the most significant stages in industrial development known to students - gems of some of these material arts which in their perfection have raised Japan to leading rank among the World's nations. ${ }^{221}$

There were nine Ainu that Starr convinced to attend the Fair consisting of two families, a young couple, and a single man (Figure 28). The young couple was Yazo Osawa, twenty-four years old (Figure 29) and his wife Shirake Osawa, eighteen years old (Figure 30). Starr described Shirake as a "pretty and attractive girl of eighteen years, timid and modest" (Figure 31). ${ }^{222}$ They came to the Fair from their home in Sapporo (Figure 32). ${ }^{223}$ Bete Goro, 26 years old (Figure 33) was also from Sapporo and left his wife when he decided to come to the Fair. Starr noted how excited Bete Goro was about going to the Fair, though originally Starr did not intend for him to

\footnotetext{
${ }^{218}$ Ibid., 79.

${ }^{219}$ Bennitt, History of the Louisiana purchase exposition, 674.

${ }^{220}$ Ibid., 674.

${ }^{221}$ Vanstone. "The Ainu Group at the Louisiana Purchase Exposition, 1904," 90.

${ }^{222}$ Frederick Starr, The Ainu Group at the Saint Louis Exposition, Chicago: Open Court Pub, 1904, 16.

${ }^{223}$ Vanstone, "The Ainu Group at the Louisiana Purchase Exposition, 1904," 81.
} 
come. He concluded with the hope that Bete Goro's happy disposition would help the moods of the other member of the Ainu group coming to the Fair.

The two families that came to the Fair were both from Piratori (Figure 34). The first was Kutoroge Hiramura who was thirty-nine (Figure 35) and his wife Shutratek Hiramura (Figure 36) with their daughter Kiko (Figure 37). ${ }^{224}$ Starr encountered Kutoroge when he was preparing to go on a bear hunting expedition and asked him to attend the Fair. Kutoroge was resigned to the idea and agreed, though it was clear he thought he was being taken to his death. This belief is represented in a conversation Starr included in his book between Mr. Bachelor (Starr's contact who was a missionary in the area and could speak the Ainu language) and Kutoroge:

Mr Batchelor to Kutoroge "oh, yes, Kutoroge, the gentlemen wants an old man, a graybeard, who knows how to make the arrow poison and to whittle the inao. Can you not find him such a man?" "Why sir, there is my old father, you know! Would he not do And really, if we must die, it is better that we should die together than separated." "Oh, yes," we answered "so there is your father! Well, go back to your village, and tell him and make preparation, so that all may be ready when we come to-morrow." 225

Since Kutoroge's father refused to go because he felt he was too old and frail. Kutoroge found another man and convinced him to bring his wife and daughter. The second family was Sangyea Himura, 57 years old (Figure 38) with his wife Santukno (Figure 39) and their daughter Kin (Figure 40). ${ }^{226}$ Starr stated that "Sangyea has graying hair, a gray beard, and a patriarchal aspect; he wears great hoop earrings and a well embroidered ceremonial garment. Santukno, his wife, is charmingly ugly, with a broad and heavy lower face, prominent jaw, and a fine tattooing on face and arms.”227

\footnotetext{
224 Ibid., 83-84.

225 Starr, The Ainu Group at the Saint Louis Exposition, 56-57.

226 Vanstone, "The Ainu Group at the Louisiana Purchase Exposition, 1904," 83-84.

227 Starr, The Ainu Group at the Saint Louis Exposition, 66-68.
} 
After Starr went to Hokkaido, he realized that the Ainu and the Japanese were completely different ethnic cultures that were not as interconnected as he had assumed, but that the Japanese were a colonizer of the land originally inhabited by the Ainu. ${ }^{228}$ This view on the Ainu had started centuries before the Fair. When Russia had become more aggressive with Japan, the Japanese assessed its ability to defend the northern islands of the country, including Hokkaido. For Japan, "it became plain that Yezo, with its own aggressive population of Ainu, was a weak spot, unprotected and easily attacked, which needed to be strengthened. A policy of colonization was developed." 229 Starr speculated that colonizing the Ainu's land was the best decision for Japan but was not good for the Ainu people. Starr was not truly concerned with the Ainu themselves, but with the preservation of their culture separate from Japanese influence. He wrote disdainfully in his book about an Ainu man he met on his trip that was married to a Japanese woman.

Starr was a strong proponent for maintaining the Ainu as an indigenous population and that the influence of Japan would corrupt what he found appealing about the Ainu culture. Starr described the Japanese colonizing stating that "In 1874 Yezo numbered 144,069 inhabitants, of whom 16,000 were Ainu; in 1899, the population was 859,534, the Ainu reported at 17,000. This flood of Japanese immigration was largely homesteaders; each year saw the Ainu more directly in contact with Japanese neighbors and less secure in the little villages which he occupies." ${ }^{230}$ Starr's perception was that "To-day the Ainu is a 'ward', to be guarded by a paternal government, to be 'elevated' by civilization." We know it as Japan does. We, too, have wards to be 'improved.",231

\footnotetext{
${ }^{228}$ Ibid., 66-68.

${ }^{229}$ Ibid., 52.

${ }^{230}$ Ibid., 54.

${ }^{231}$ Ibid., 75-76.
} 
The Ainu at the 1904 St. Louis World's Fair

The Japanese had the clear goal of being viewed as a colonial power separate from the Ainu and not as another step in the anthropological hierarchy of which McGee was a proponent. This is evident from the experiences Starr witnessed. Starr described a situation he encountered when he arrived in the United States with the Ainu group that highlighted the Japanese position on the Ainu stating:

Little Kiko was hungry and Shutratek, like a good mother, was doing her natural duty by the baby. The secretary of the Japanese Consul had come in to see the Ainu; he was all smiles until he saw Shutratek and the baby. His rebuke was vigorous and probably the poor woman was warned against the future public care of her baby. The Japanese are fearful lest we shall make the error of thinking that the Ainu are their ancestors or that we shall suppose the Japanese culture has come from the Ainu! $!^{232}$

The interactions between the Ainu and the Japanese consul can be examined through postcolonial theory. For Said the theory is seen as "the relationship between occident and orient is a relationship of power, of domination, of varying degrees of a complex hegemony."${ }^{233}$ In this circumstance, Japan strove to be viewed as superior and dominating over the Ainu. For Starr, the Ainu were an underdeveloped culture that needed to be protected as they "evolved." This type of viewpoint is indicated multiple times in Starr's recollection of his trip. He describes the translation for the name 'The Ainu' which means 'the men' in the Ainu language. Starr sees this as a "common thing for people in a certain stage of culture to name themselves this way." 234 This statement serves to reinforce Starr's agreement with McGee's anthropological hieratical vision.

The focus at the Fair was on their dress and physical appearance and the ways in which it differed from the Japanese culture and from Westerners. The Ainu would weave patterns into

\footnotetext{
232 Ibid., 98.

${ }^{233}$ Said, Orientalism, 13.

${ }^{234}$ Ibid., 95.
} 
their clothes that were meant to protect them from evil spirits. ${ }^{235}$ These garment patterns can be seen especially well in the image of Sangyea of Piratori (Figure 38) and in the image of an Ainu woman wearing attush garment with magical embroidery (Figure 42) but are present in all the garments worn by the Ainu. Designs were concentrated around the openings of the garments to provide protection. The symbols focused around the garment openings can be seen in the photograph from Starr's trip to Hokkaido in the photograph of Woman's Dress of Elm-Bark Cloth, Earrings, and Necklace (Figure 43). The patterns were generally in dark blue, like the facial tattoos, and consisted of woven symbols. ${ }^{236}$ These symbols would often also be tattooed on women's arms for further protection (Figure 44). ${ }^{237}$ Starr stated that "The hands and the arms to the elbows are also tattooed with a system of rings, dots, zigzags, etc., which appear to be largely individual. ${ }^{, 238}$ In the photograph Women Pounding Millet (Figure 45), from Starr's trip to Hokkaido, the arm tattoos on women can be seen.

Images of the Ainu at the Fair were clearly meant to portray them as a simple people (Figure 49 and 50), there were often simple tools or items in the photograph with them. The simple nature of the Ainu that was portrayed was viewed in opposition to the modernization of the Japanese. This left Japan appearing to be the colonizers of the Ainu. Starr's group brought two small Ainu houses from Shiraoi that were deconstructed to be reconstructed as a larger house at the Fair (Figure 48). They were photographed working around their house, such as in the image of the women using a large mortar and pestle (Figure 49). The women were photographed in front of the housing at the Fair, working and doing household chores (Figure 50). Visitors to the Fair were fascinated by the Ainu; most Japanese had never even seen the

\footnotetext{
${ }^{235}$ Krutak, Tattooing Among Japan's Ainu People, 60-68.

${ }^{236}$ Ibid., 60-68.

${ }^{237}$ Ibid., 60-68.

${ }^{238}$ Starr, The Ainu Group at the Saint Louis Exposition, 39.
} 
Ainu making them a rare novelty to Westerners. ${ }^{239}$ "One enthusiastic writer referred to the Ainu as "mysterious little Japanese primitives" and noted that the visitors were impressed by their cleanliness and polite manners (Figure 51), but somewhat disappointed that they were not 'maneaters, dog-eaters, or wild men."

The Ainu displayed at the Fair served to influence the reception of Japan by the United States. Japan used its colonial relationship the Ainu people to appeal to western ideals and were able to gain recognition for the dominance over a group that the West viewed as a 'white race.' This perception of the relationship between Japan and the Ainu also served as a justification for Westerners as to how Japan could win the Russo/Japanese war.

${ }^{239}$ Vanstone, "The Ainu Group at the Louisiana Purchase Exposition, 1904," 85.

${ }^{240}$ Ibid., 86. 


\section{Conclusion}

In conclusion, by examining the primary source material there seems to be a correlation between Japan's self-portrayal and the perception of the Japanese by the United States. This was especially evident when examining Hajime Hoshi’s guidebooks in comparison to Marshall Everett's guidebook. Japan was able to focus on the aesthetic qualities of its art, people, and technology to fashion itself an identity, that they wanted to present to the United States. Throughout the guidebook and handbooks discussed, the reception of Japan that appears in print is overwhelmingly positive. People seemed fascinated with the skill of the Japanese people, from the beauty and grace of the Geisha to the sleek technological advancements that were showcased at the Fair. Japan took advantage of the World's Fairs that occurred from almost the moment their borders were forcibly opened to the West. By pushing a specific influential narrative at the Fairs, Japan was able to influence people's perception and understanding of Japanese culture in the United States. A success of the influence of reception at the 1904 World's Fair was the ability for the Japanese to coerce the narrative surrounding the Russo/Japanese war and the sequence of aggressive behavior Japan had pushed on their neighboring countries.

Throughout this paper, the examination of guidebooks and photographs from the Fair provided a basis for the discussion of Japanese reception by the United States. It discusses the importance of Japanese development over the second half of the nineteenth century through the Meiji Restoration by using World's Fairs as an international platform. Reception theory provides the theoretical groundwork to discuss the interaction between Japan and the United States that occurred at the Fair. These interactions were an important part of the understanding of Japan that developed. Japan's focus on aesthetics set the stage for a dual identity that made their military prowess appear nonthreatening to the United States and yet garnered respect. Japan treaded the 
line between colonizer and colonized by attempting to manage the display of the Ainu at the Fair, to its benefit.

This research presents the opportunity for further examination of the significance of guidebooks and how the nationality of the writer can provide a look at the inherent opinions of other countries and nationalities. In the comparison between Japanese and Western guidebooks the racist tones and cultural misunderstandings are clear in the language of the text. The application of reception theory to the guidebooks is effective in revealing the bias and racist perspectives of western authors and fair organizers. The theory also helps to draws attention to the discrimination against indigenous populations that was common at the turn of the twentieth century. The guidebooks provide a platform for an examination of cultural interactions through the application of reception theory. The guidebooks alongside photographs from World's Fairs allow for an analysis of the social, political, and cultural undertones present in a given period of history. 


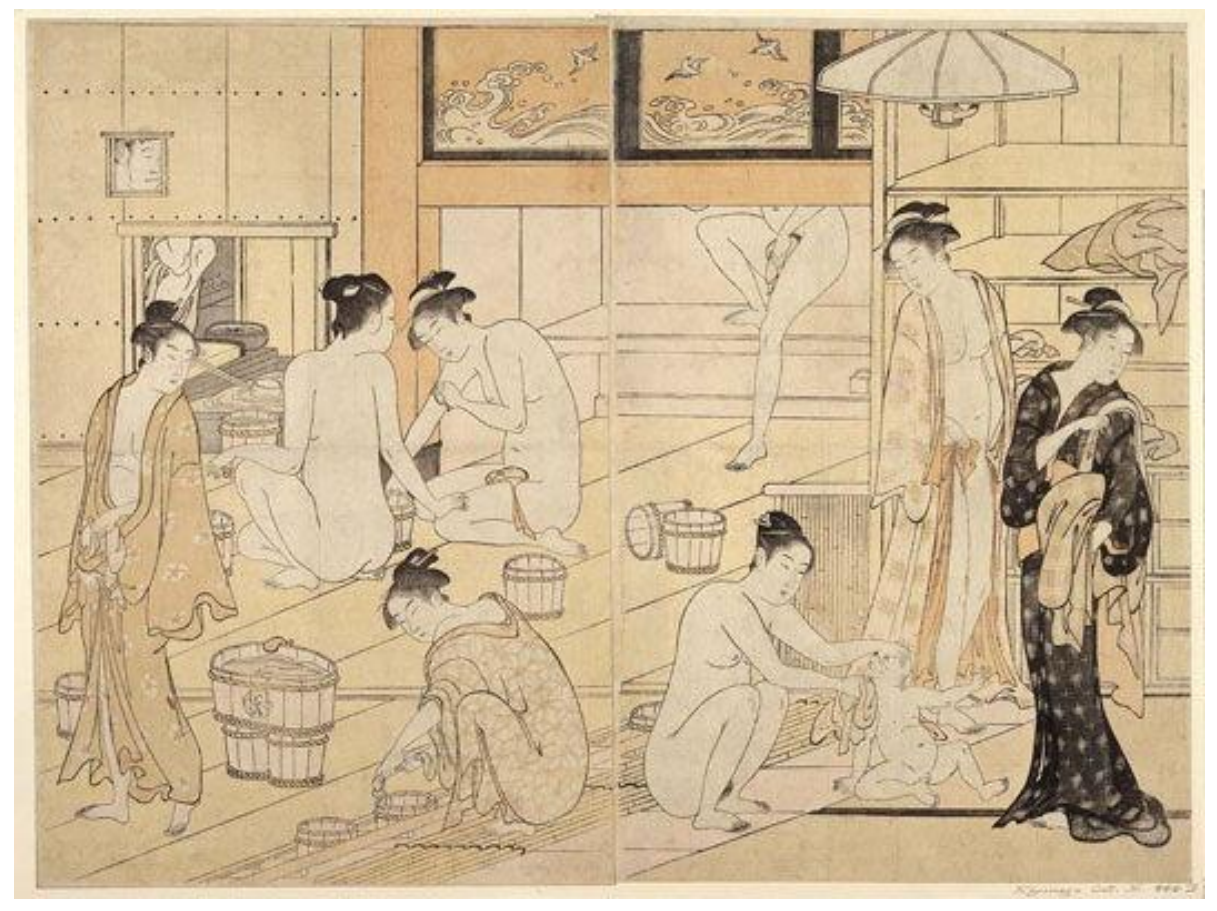

Figure 1. Torri Kiyonaga, Interior of a Bathhouse,1787, Museum of Fine Arts, Boston, MA

Figure 2. Katsushika Hokusai, Under the Wave off Kanagawa (also known as The Great Wave), 1830-32, Metropolitan Museum of Art, New York, NY

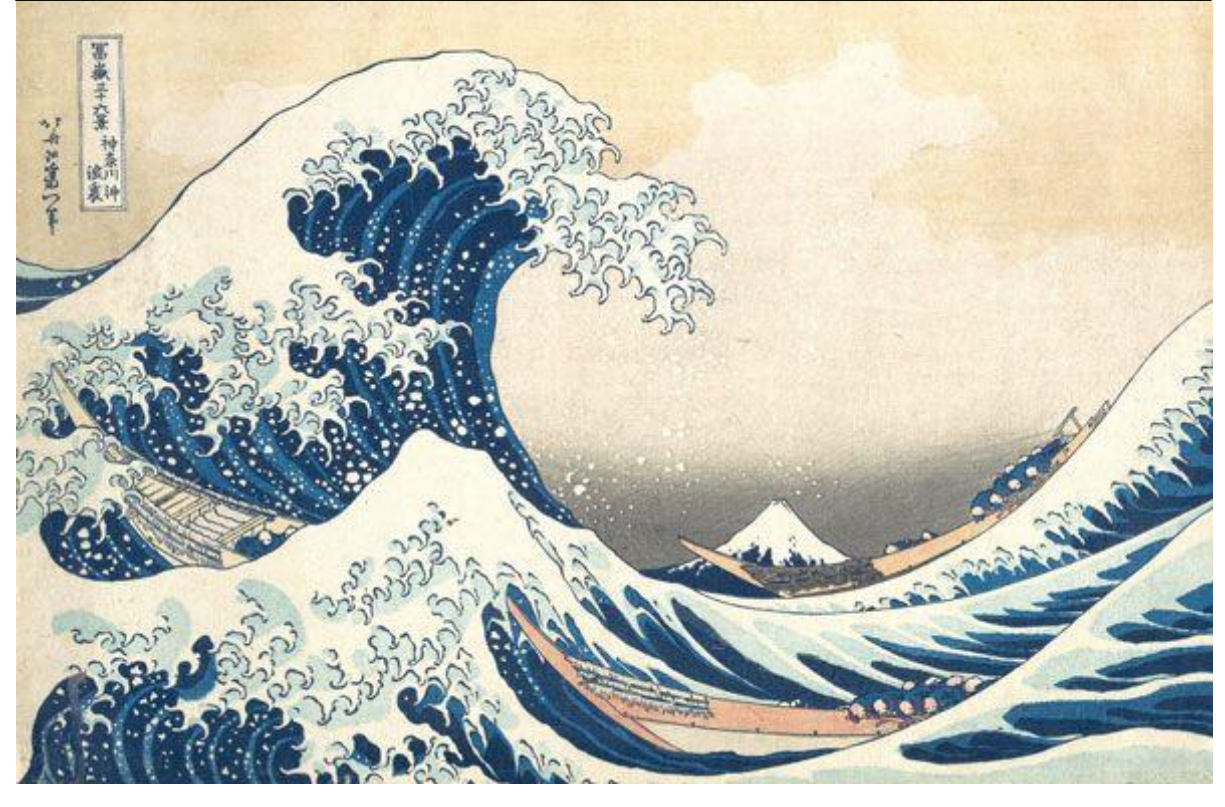




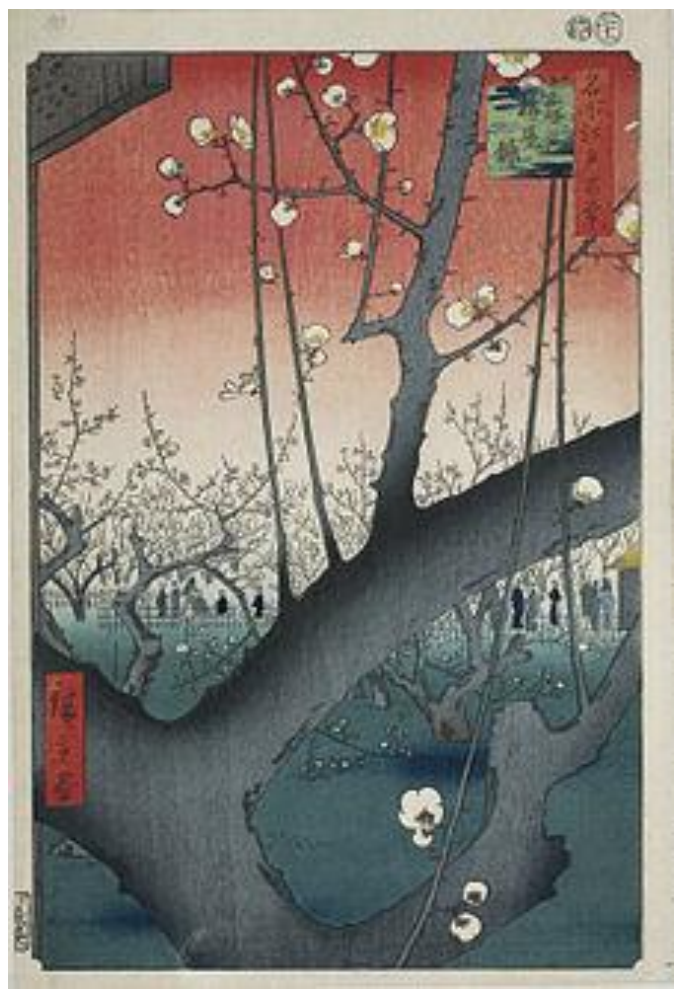

Figure 3. Utagawa Hiroshige, Plum Estate, Kameido (Kameido Umeyashiki), 1857, Brooklyn Museum of Art, Brooklyn, NY

Figure 4. Vincent van Gogh, Flowering Plum Orchard (after Hiroshige), 1887, Van Gogh Museum, Amsterdam

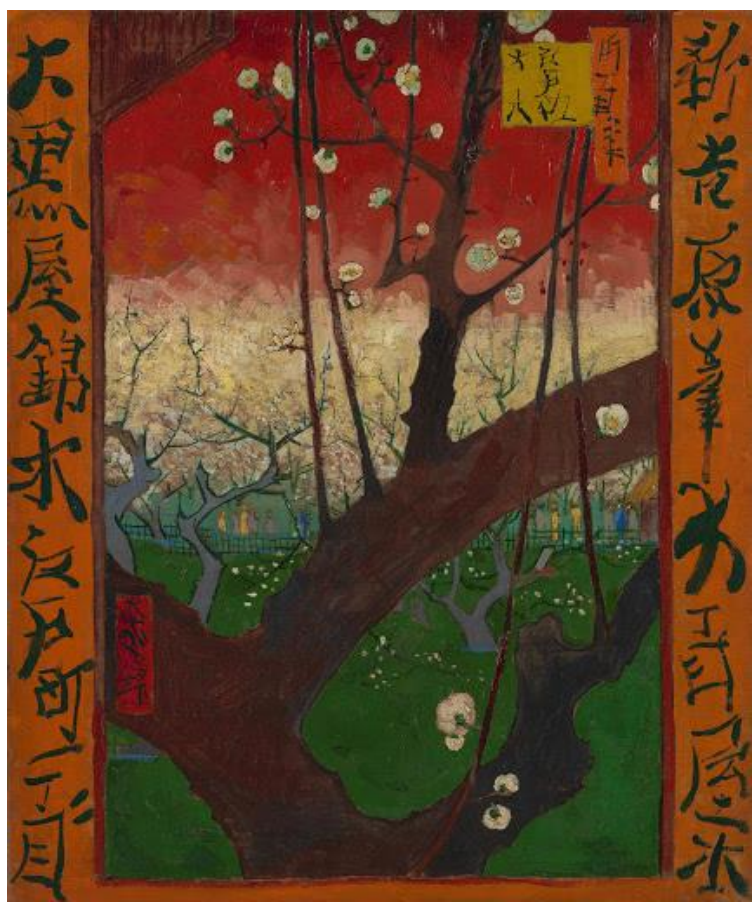




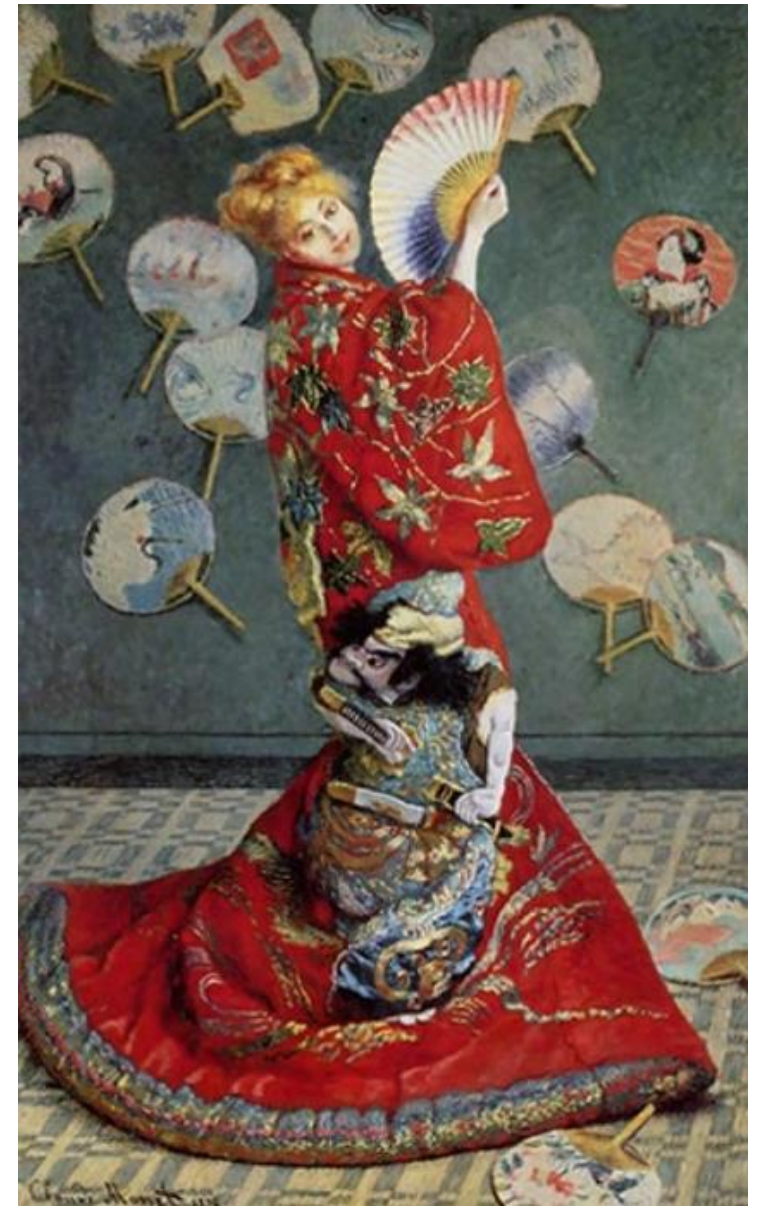

Figure 5. Claude Monet, $\mathrm{La}$ Japonaise, 1876, Museum of Fine Arts, Boston, MA

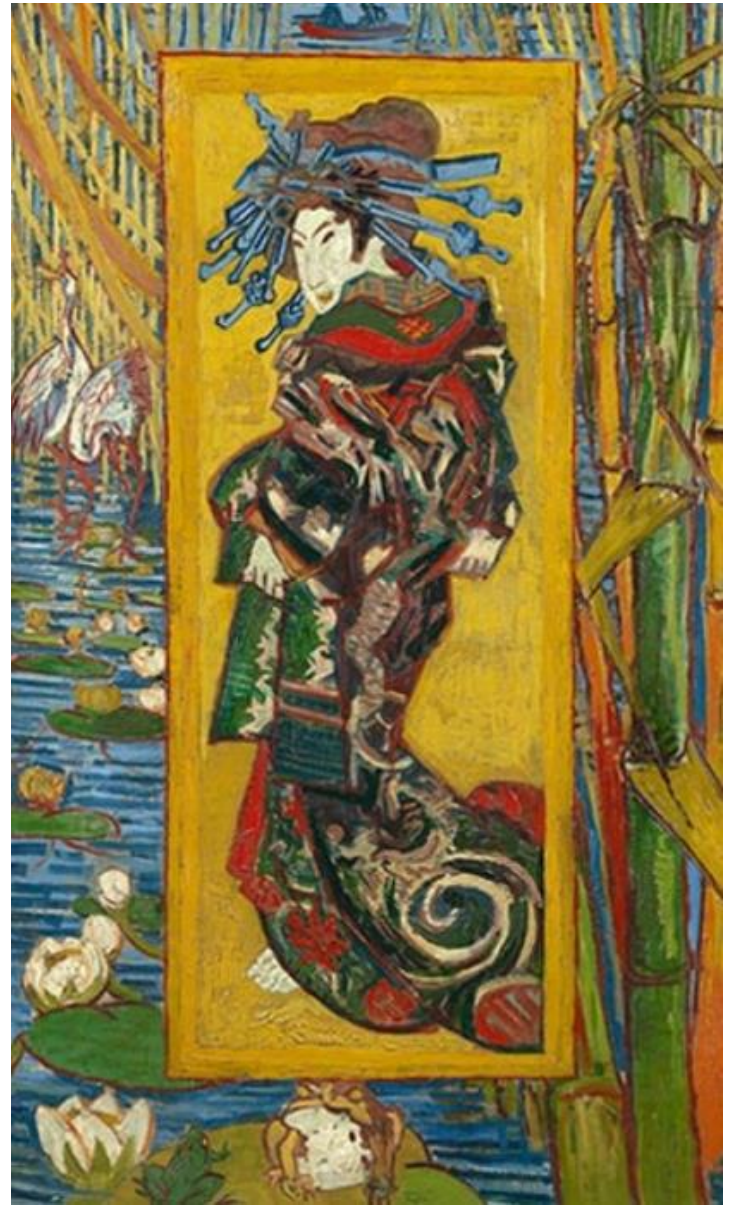

Figure 6. Vincent Van Gogh, The courtesan (after Eisen), 1887, Van Gogh Museum, Amsterdam, NL 


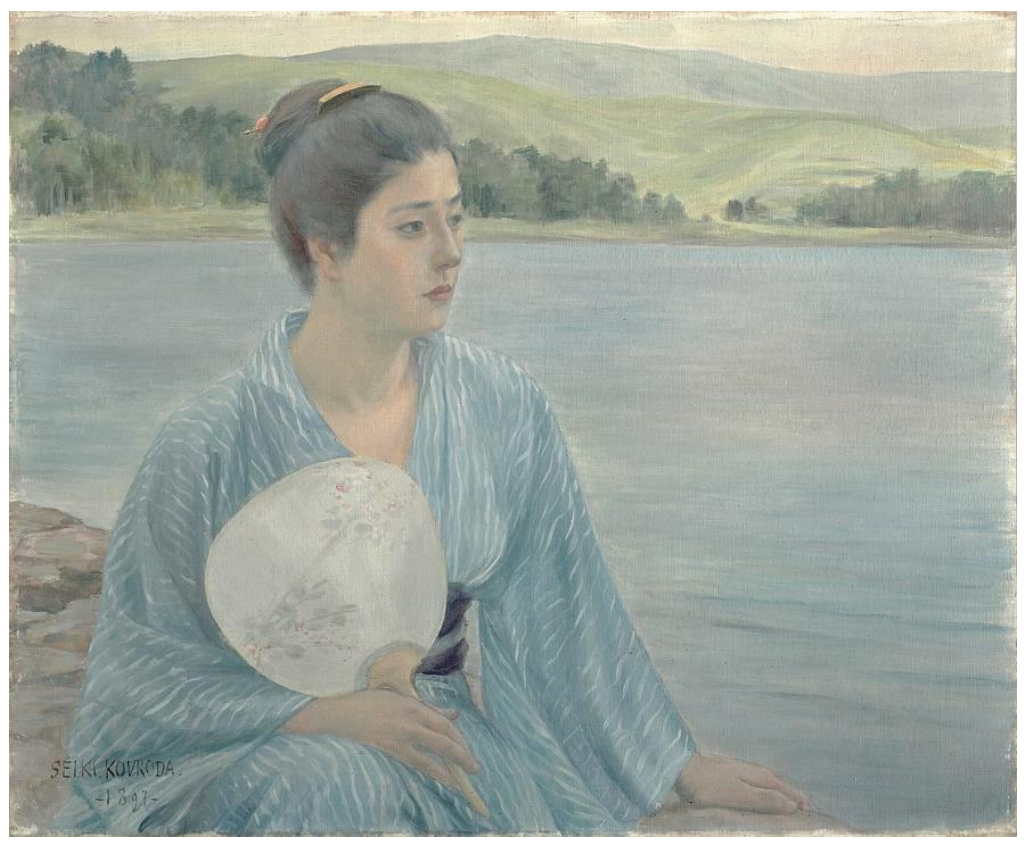

Figure 7. Kuroda Seiki, Lakeside, 1897, Kuroda Memorial Hall, Tokyo, JP

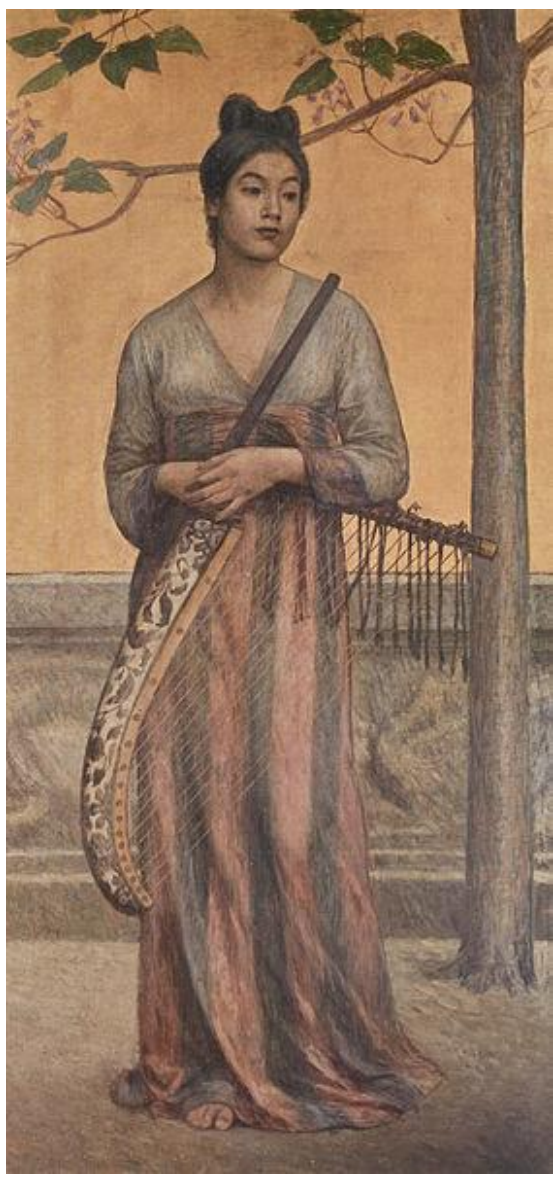

Figure 8. Fujishima Takeji, Reminiscence of the Tempyo Era, 1902, Ishibashi Museum of Art, Kurume, Fukuoka, JP 


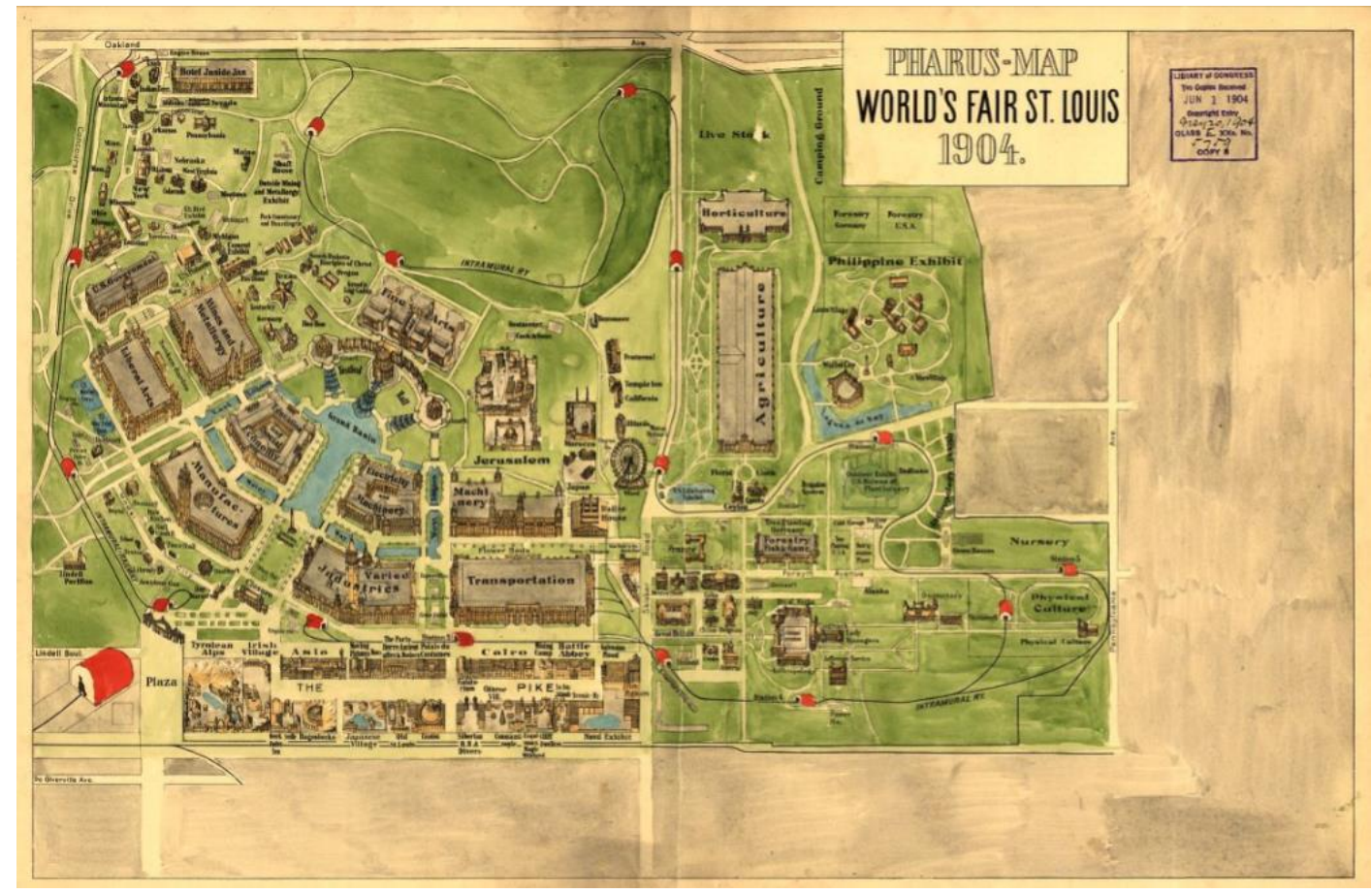

Figure 9. Pharus-map World's Fair St. Louis, 1904, Library of Congress Geography and Map Division Washington, D.C.

Figure 10. Floor Plan of West Art pavilion of the Palace of Fine Arts, St. Louis, Saint Louis Art Museum, c.1904.

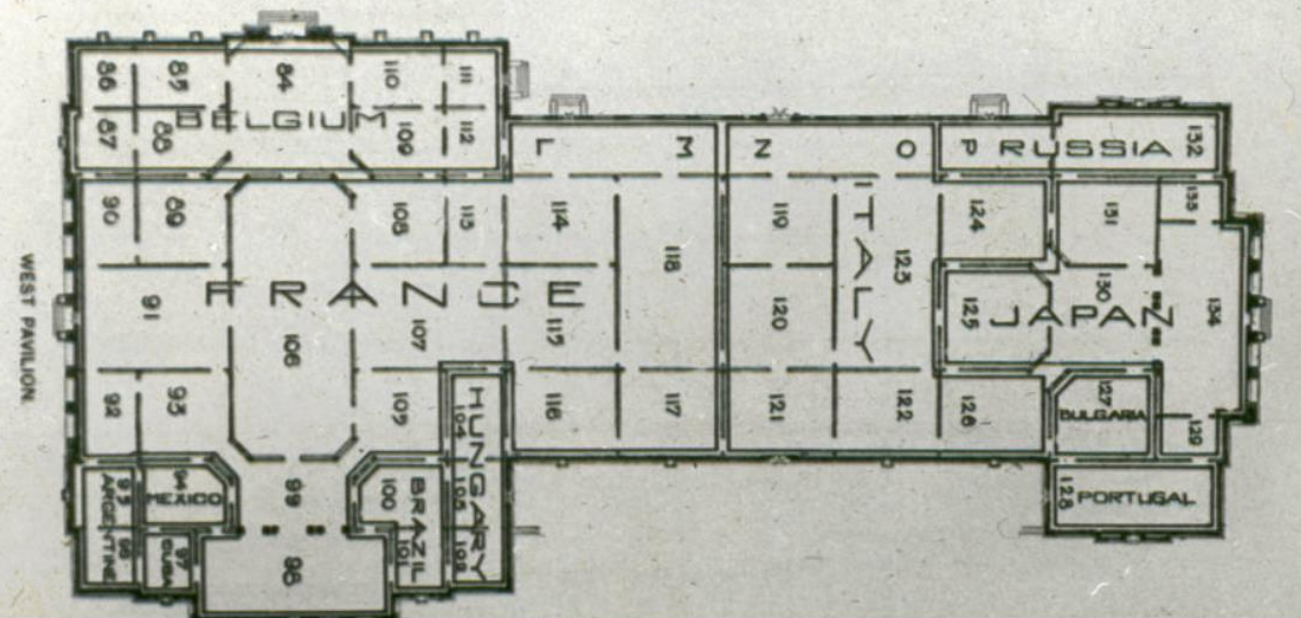


Figure 11. Japanese Golden Eagle. From Everett, Marshall, The book of the Fair: the greatest exposition the world has ever seen photographed and explained, a panorama of the St. Louis exposition, Philadelphia: P.W. Ziegler, 1904.

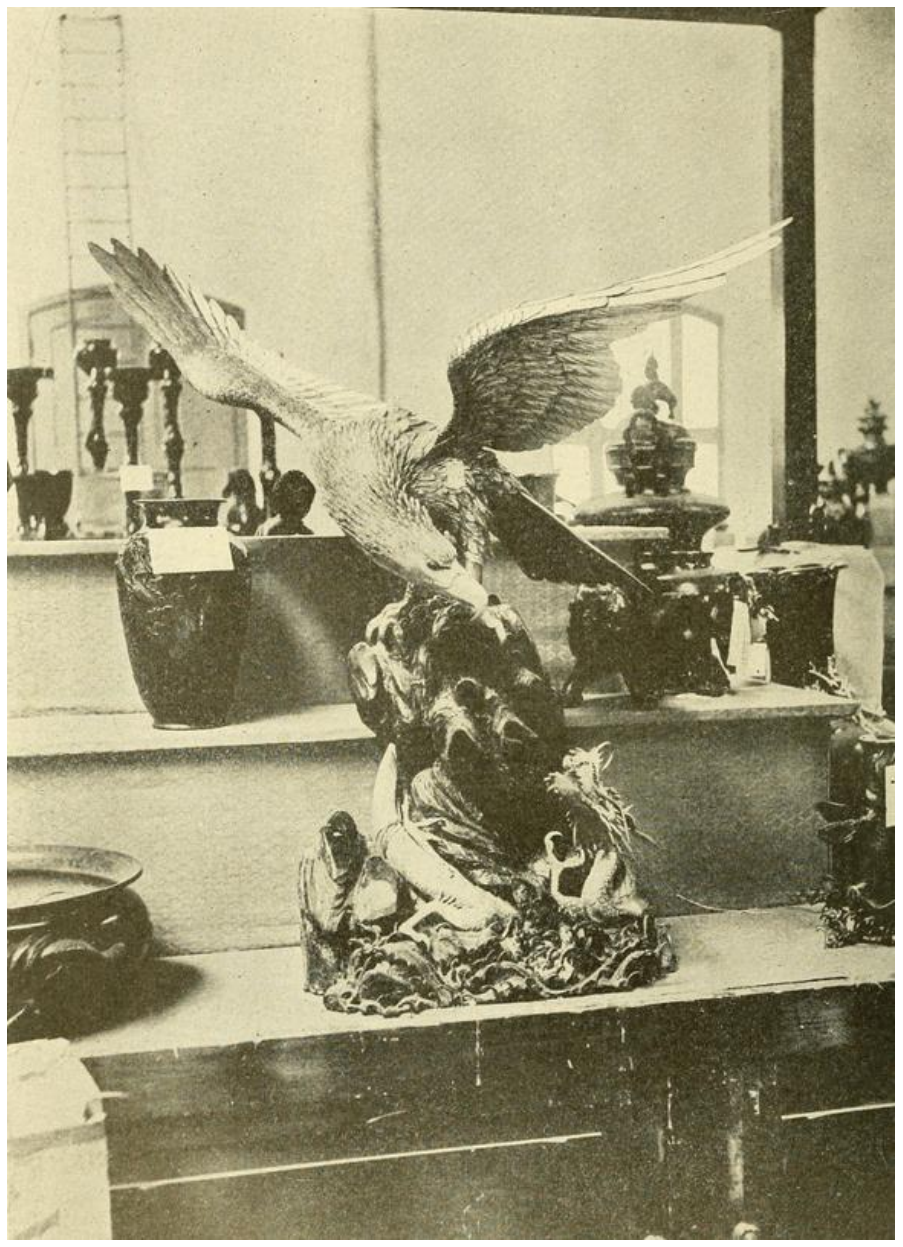


Figure 12. Japanese Exhibit in Palace of Varied Industries, St. Louis: Official Photographic Company of the Louisiana Purchase Exposition, c.1904.
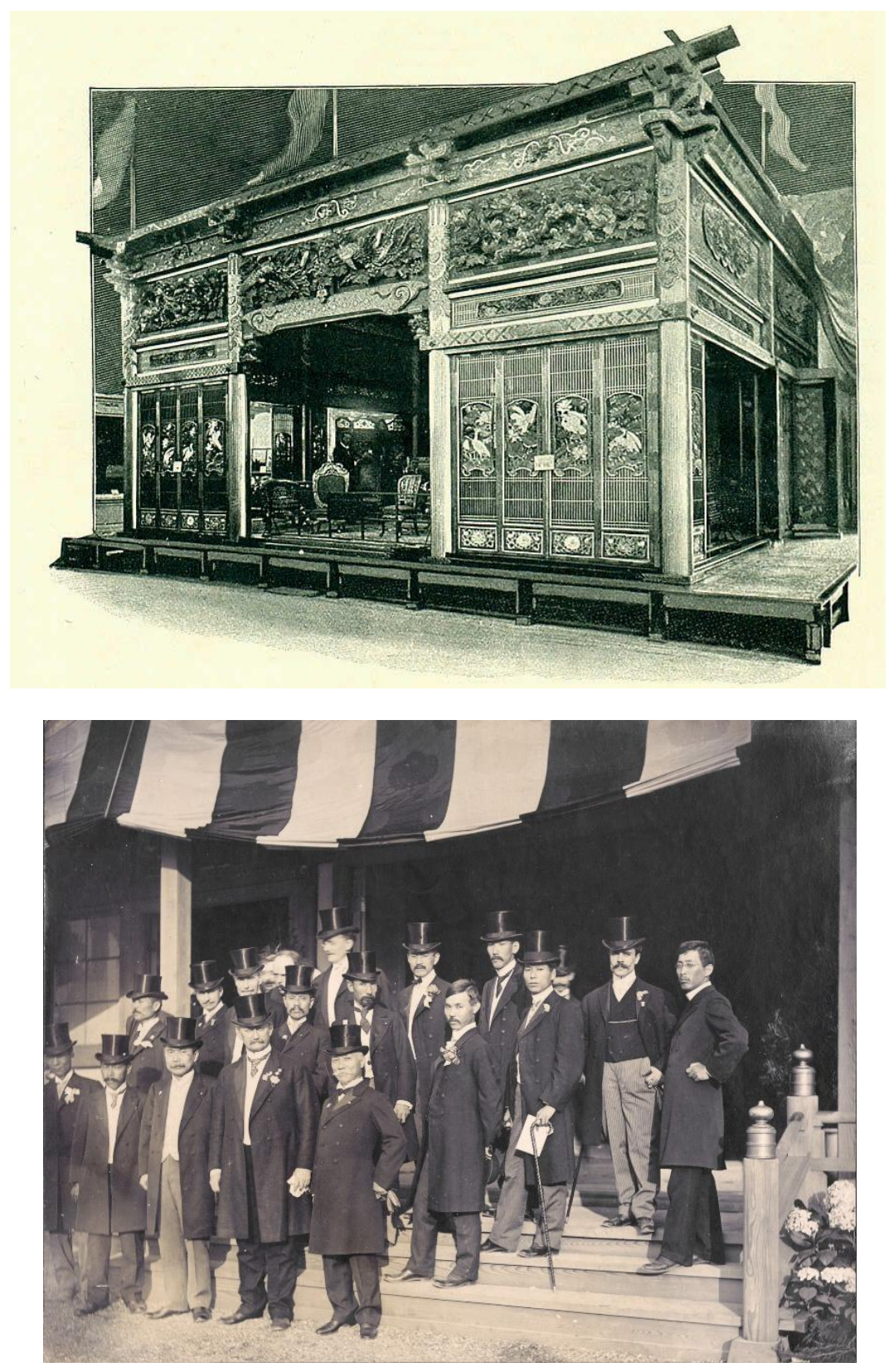

Figure 13. "The Japanese Representation," (Japanese Commissioners group) at the 1904 World's Fair, Missouri Historical Society 
Figure 14. Birdseye view of the Japanese Garden. Rau, William H., The greatest of expositions completely illustrated: official publication. St. Louis: Official Photographic Company of the Louisiana Purchase Exposition, 1904.

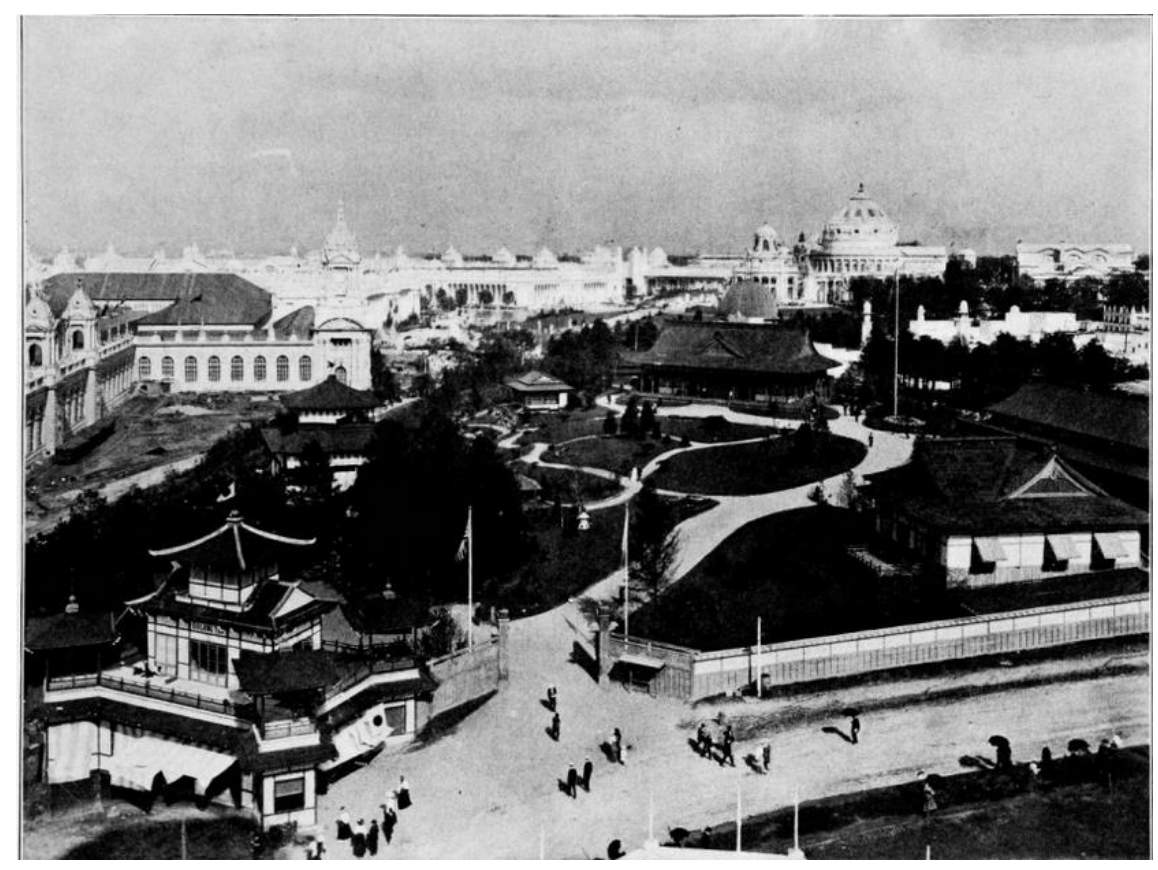




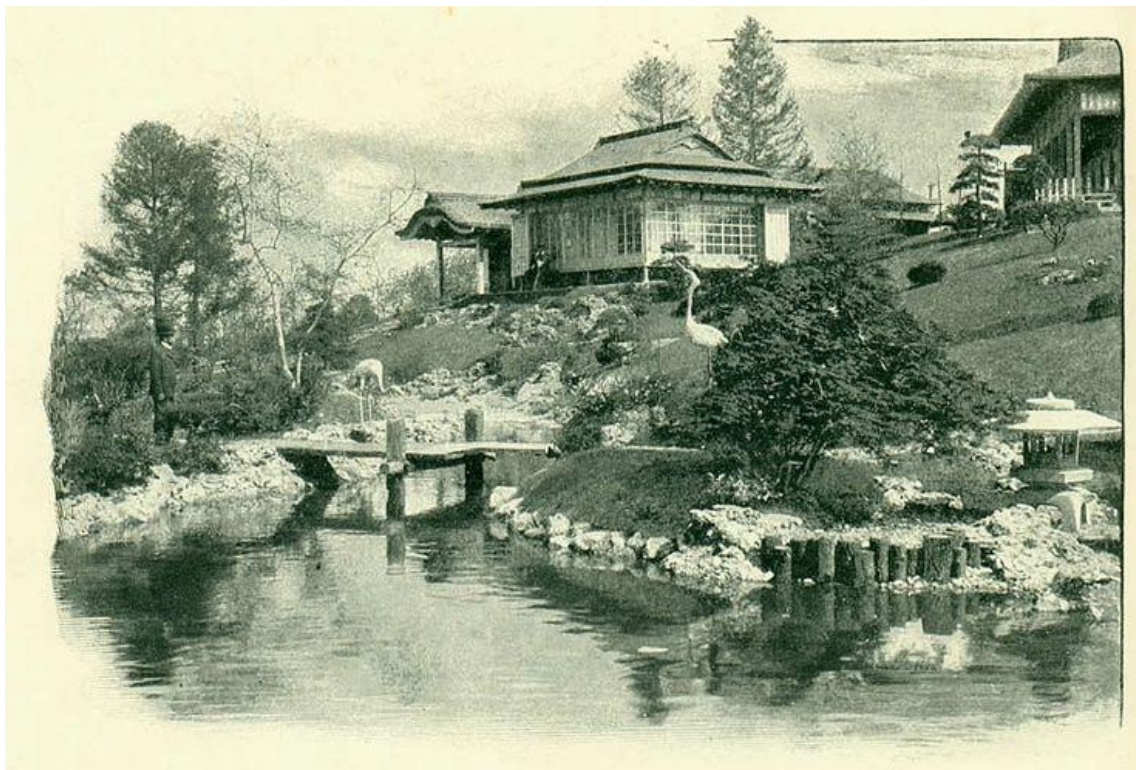

PAVILION, AND SPECIMEX OF LANDSCAPE-GAKDENING, IN THE GROUNDS OF THE JAPANESE EXHBBIT.

Figure 15. Pavilion, and Specimen of Landscape-Gardening, in the grounds of The Japanese Exhibit, 1904

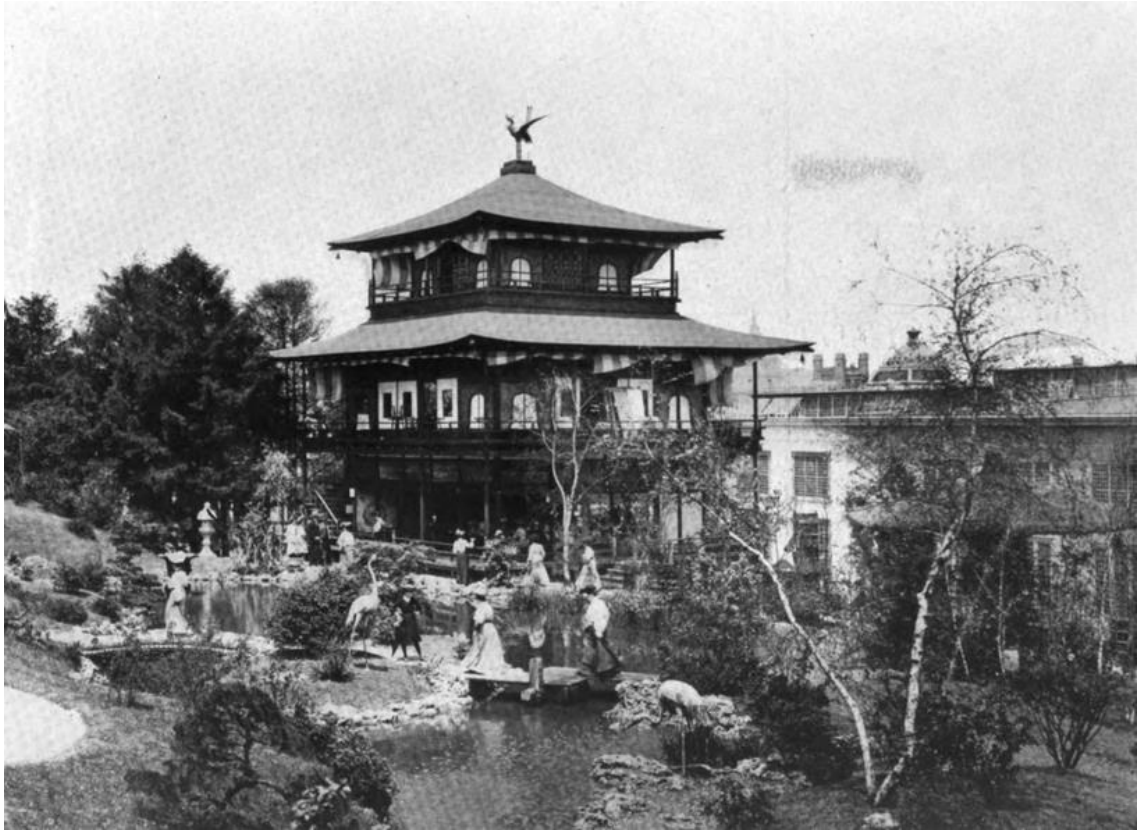

Figure 16. Japanese Gardens and Tea-Houses, St. Louis: Official Photographic Company of the Louisiana Purchase Exposition, c.1904. 


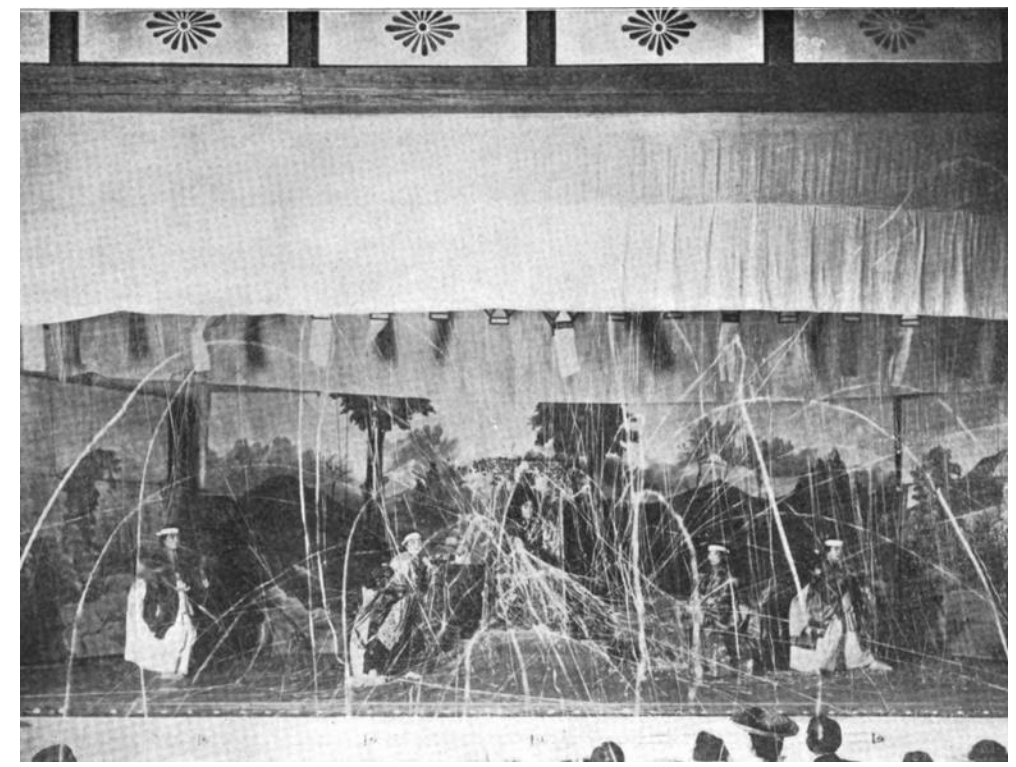

Figure 17. The Spider Play in Fair Japan, St. Louis: Official Photographic Company of the Louisiana Purchase Exposition, c.1904.

Figure 18. Entrance to Fair Japan, St. Louis: Official Photographic Company of the Louisiana Purchase Exposition, c.1904.

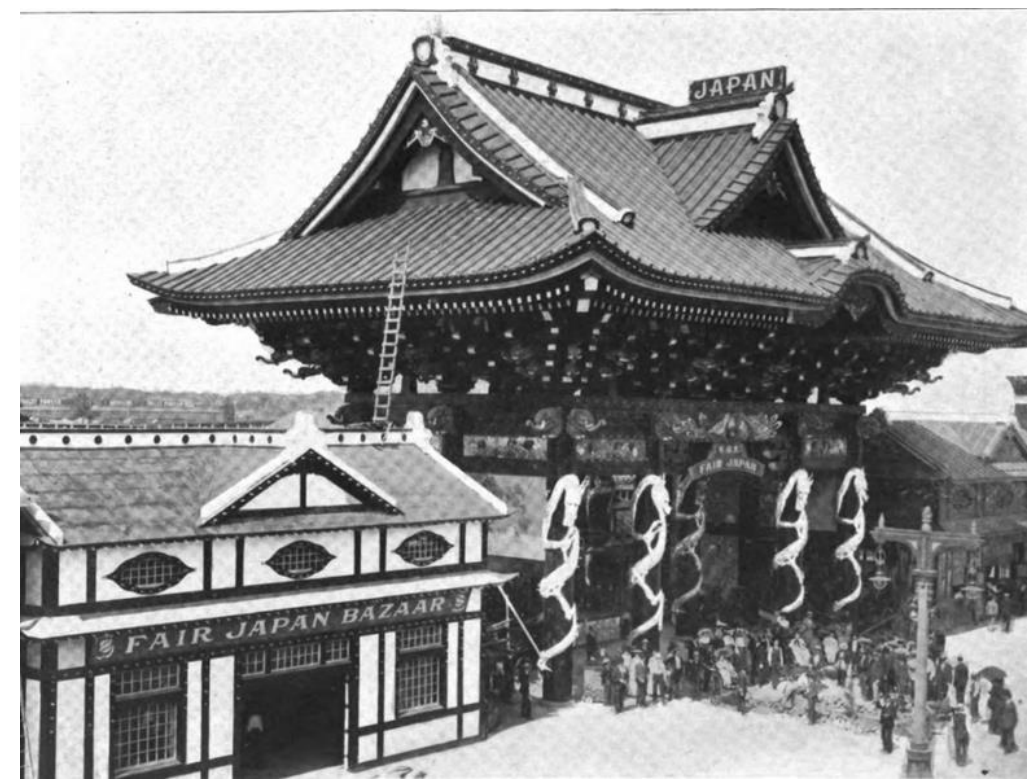




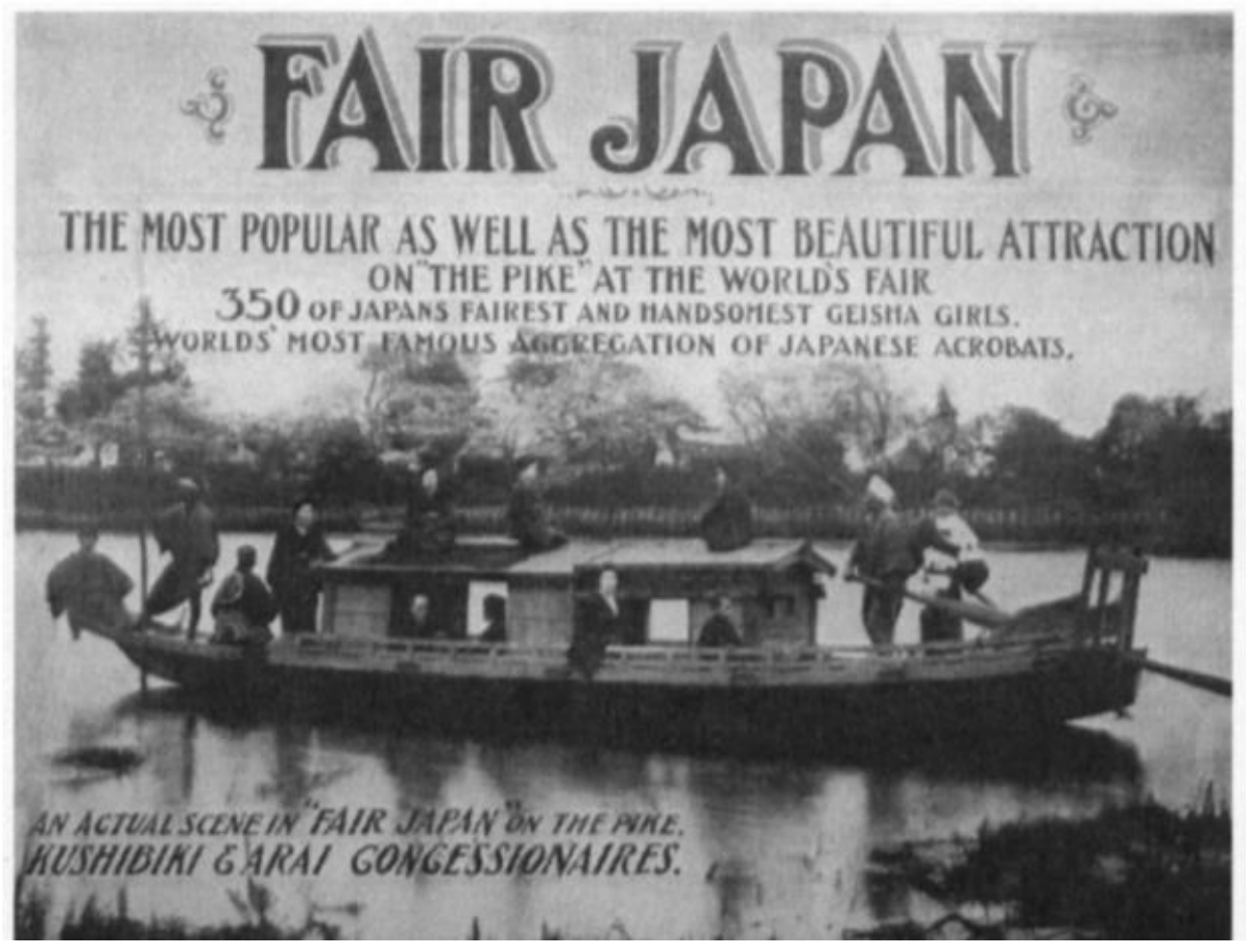

Figure 19. "Fair Japan" the most popular as well as the most beautiful attraction on the Pike at the World's Fair, advertisement, 1904. 
Figure 20. James McNeill Whistler, Rose and Silver: The Princess from the Land of Porcelain,1865, Freer Gallery of Art, Washington D.C.

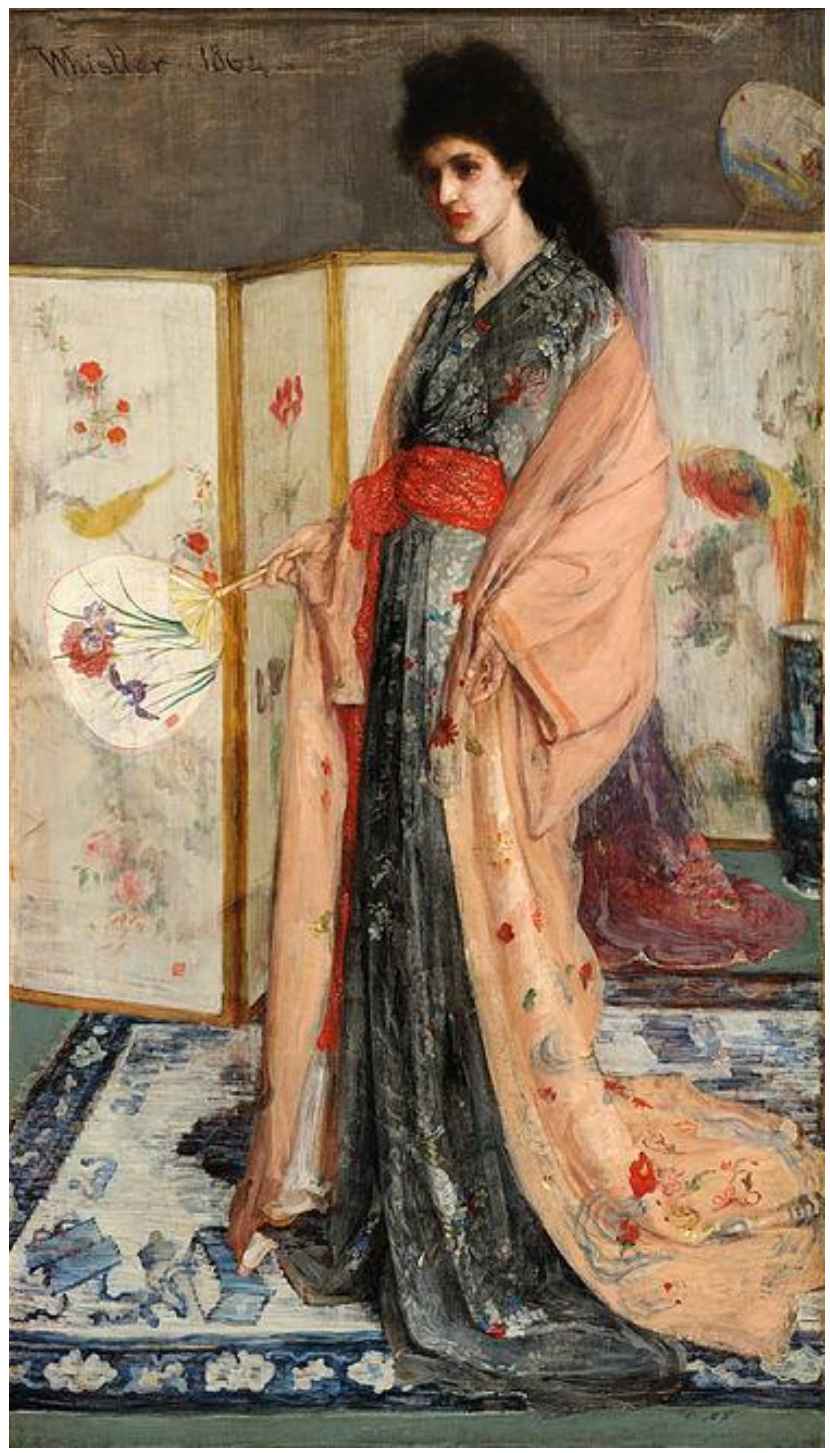




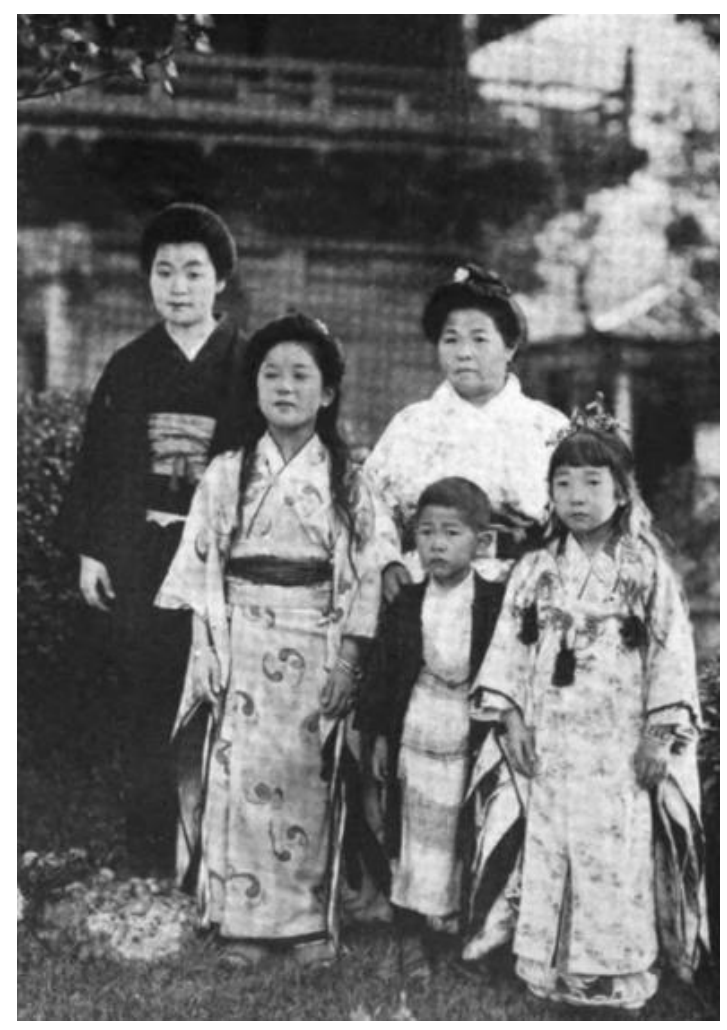

Figure 21. Types of People, Japanese Ladies and Children, St. Louis: Official Photographic Company of the Louisiana Purchase Exposition, c. 1904.

Figure 22. Geisha Girls in Fair Japan, St. Louis: Official Photographic Company of the Louisiana Purchase Exposition, c.1904.

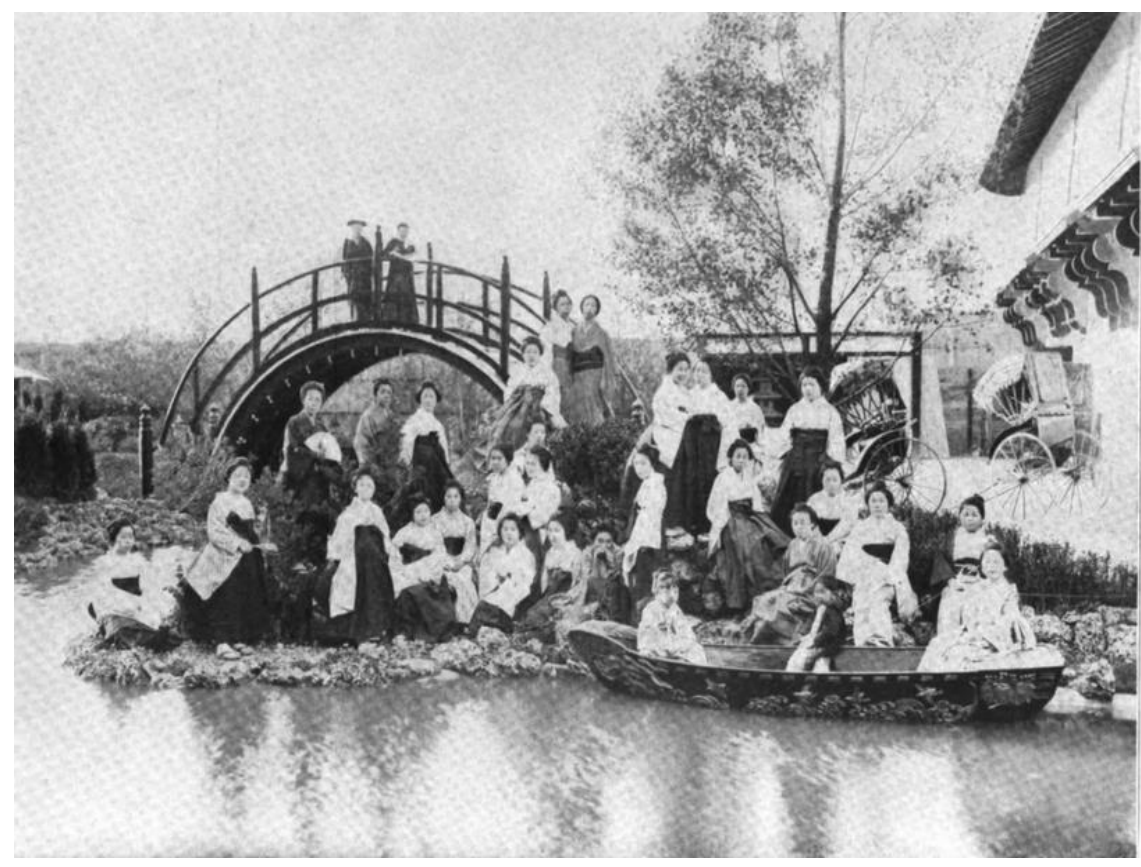




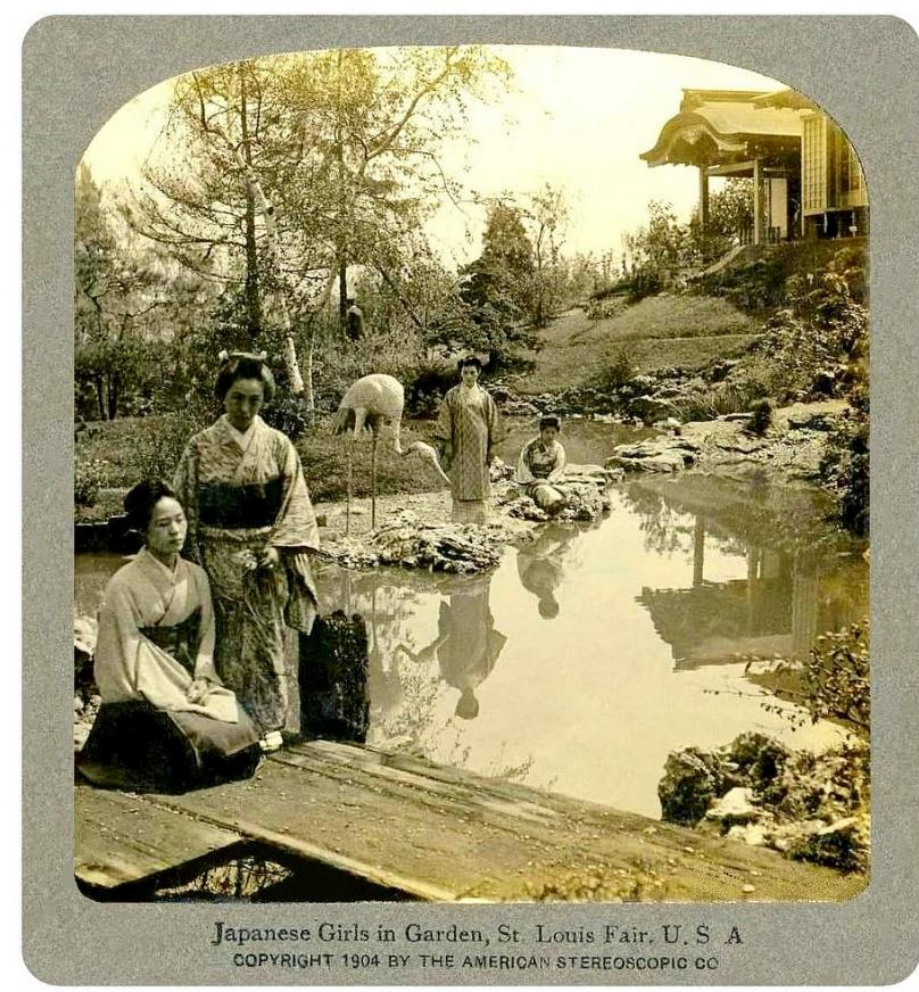

Figure 23. Japanese Girls in the Garden, St Louis Fair, 1904.

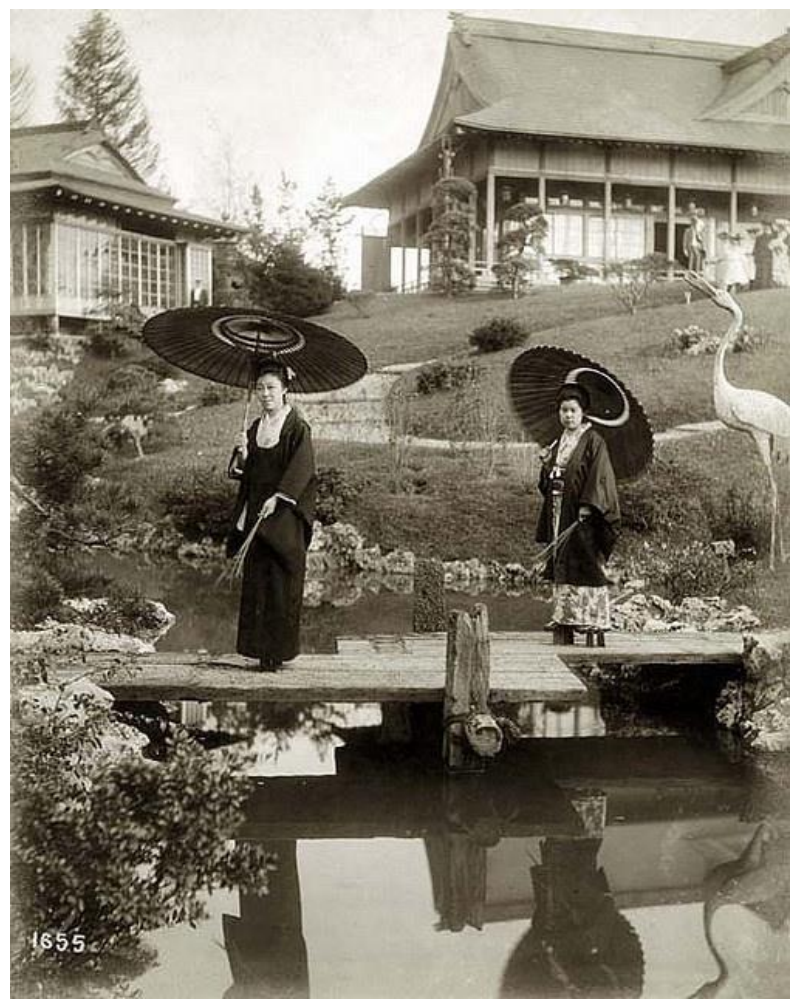

Figure 24. Japanese Garden at the World's Fair, 1904. 


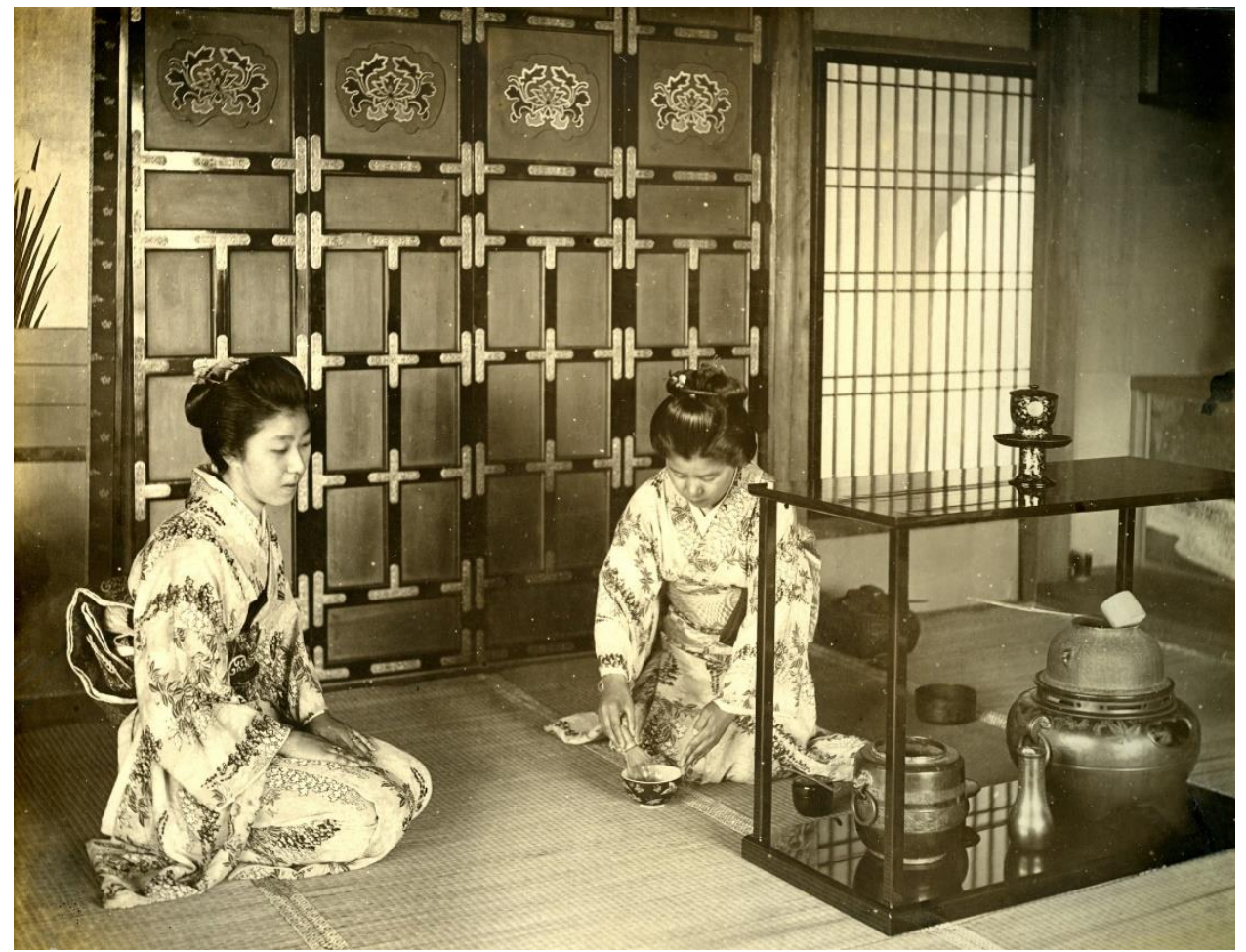

Figure 25. Interior of Japanese Home [Japanese Reservation] (1904 World's Fair) Missouri Historical Society

Figure 26. Drinking Tea in a Japanese Pavilion. St. Louis: Official Photographic Company of the Louisiana Purchase Exposition, c.1904.

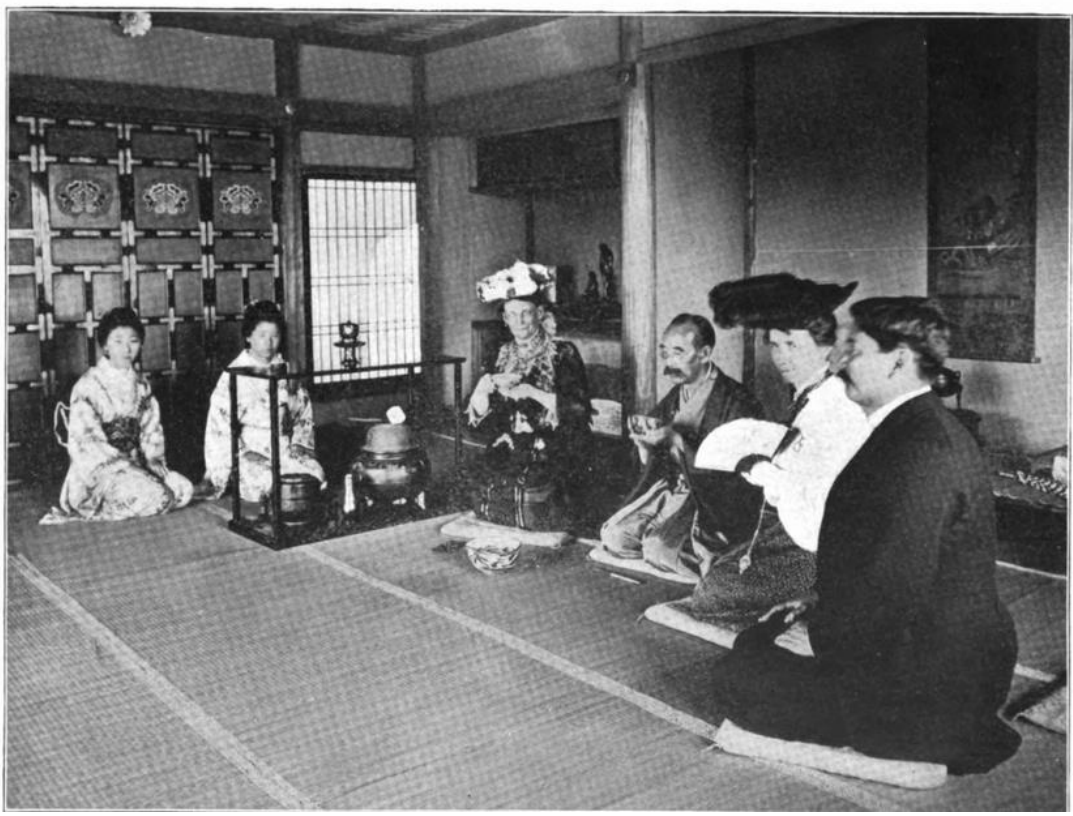




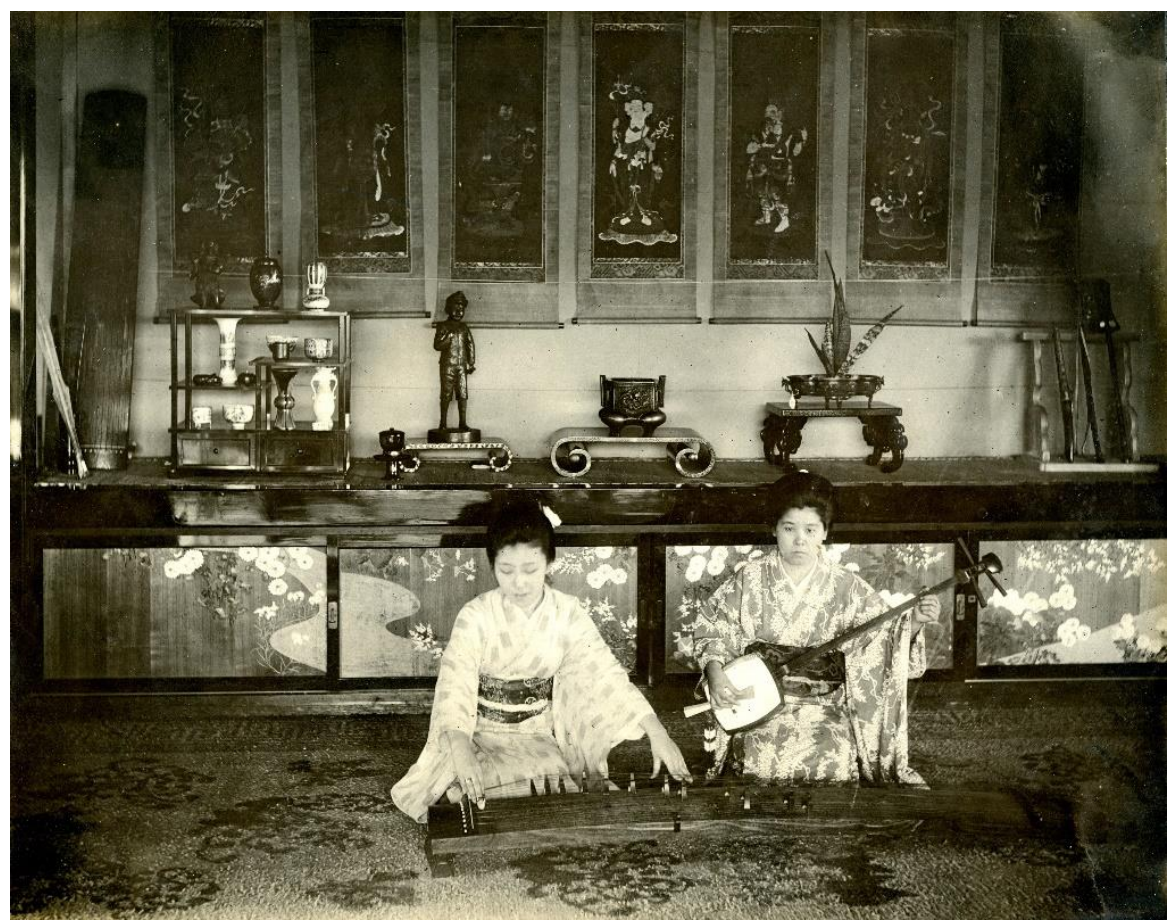

Figure 27. Japanese Ensemble [Japanese Reservation] (1904 World's Fair), Missouri Historical Society

Figure 28. Frederick Starr, The Ainu Group at the Saint Louis Exposition, Chicago: Open Court Pub, 1904.

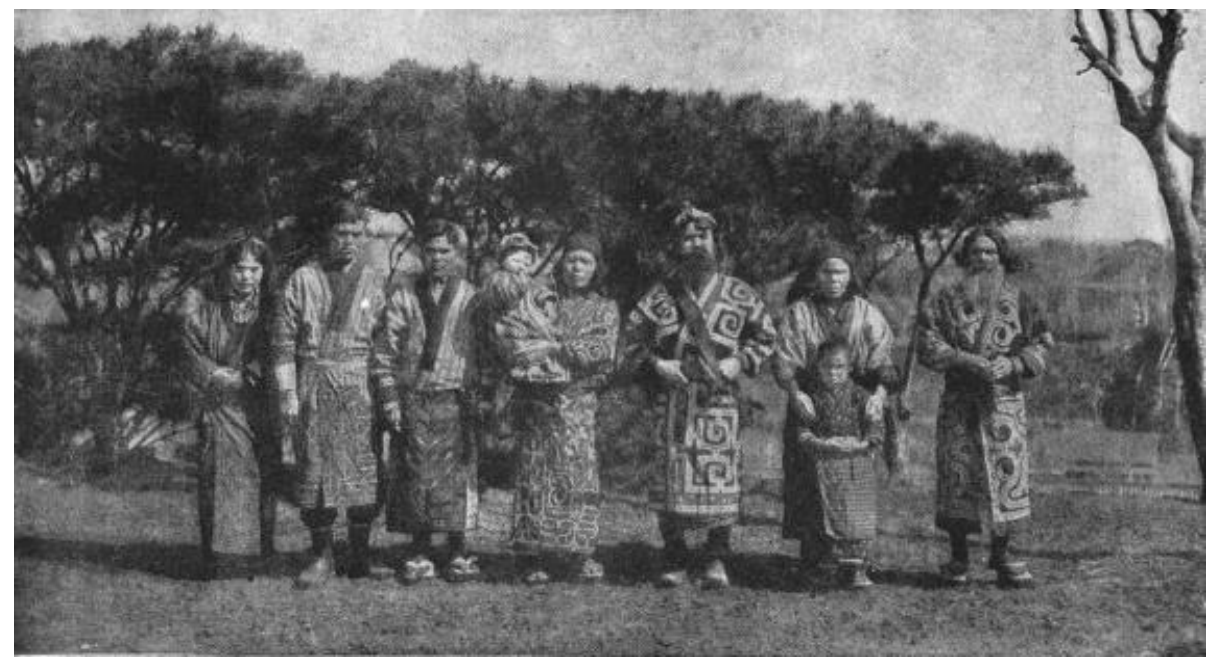




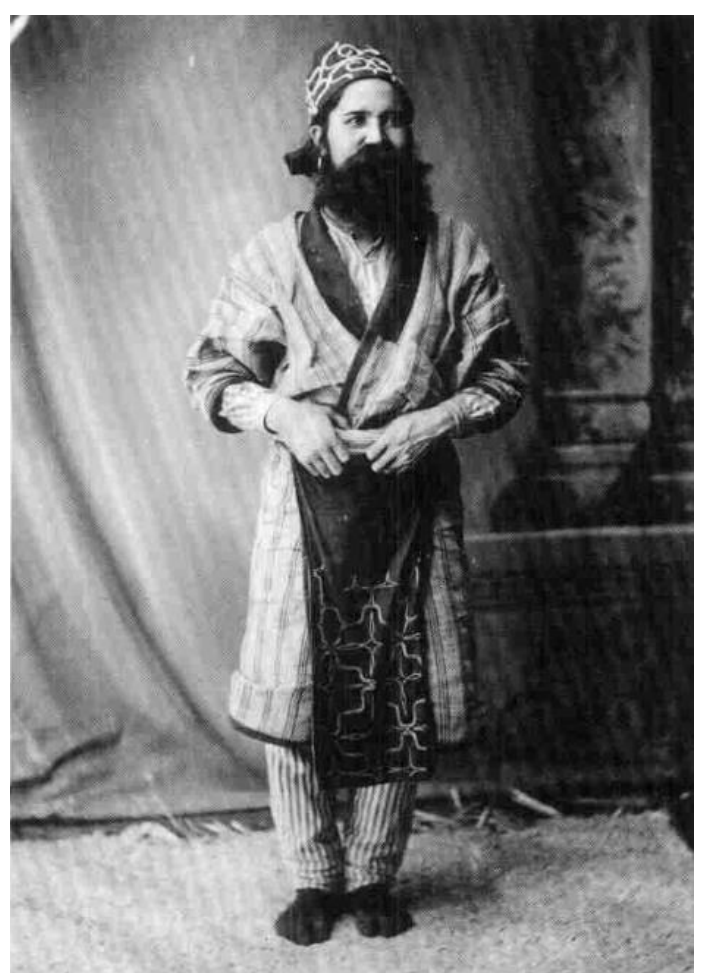

Figure 29. Yazo of Sapporo

Field Museum of Natural History, neg. no. 13218. Chicago.

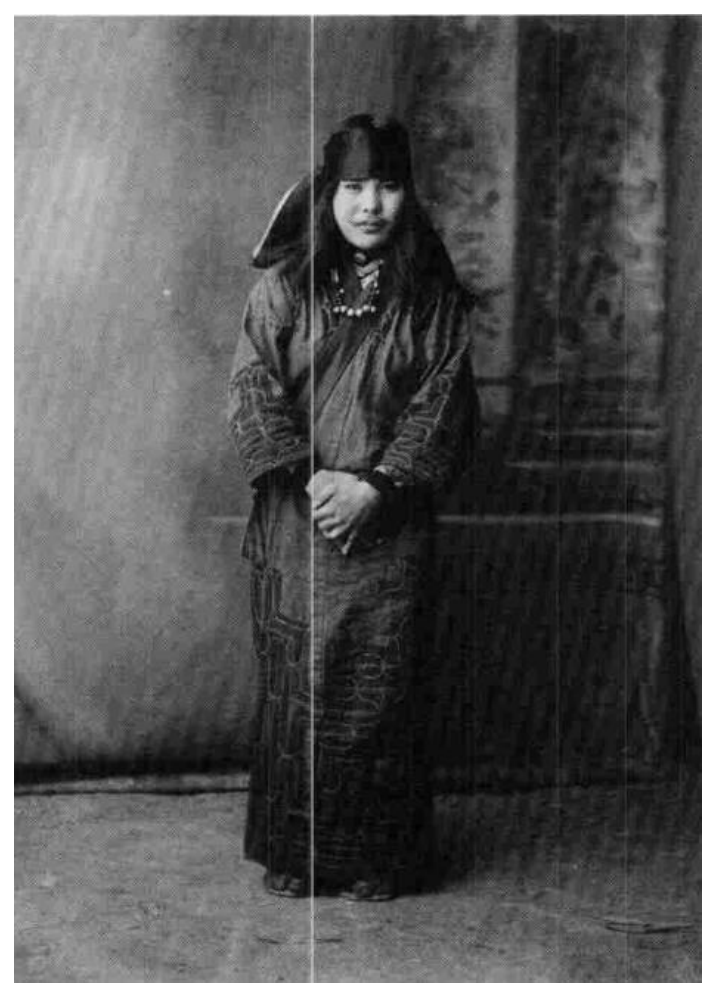

Figure 30. Shirake, wife of Yazo

Field Museum of Natural History, neg. no. 13192. Chicago.

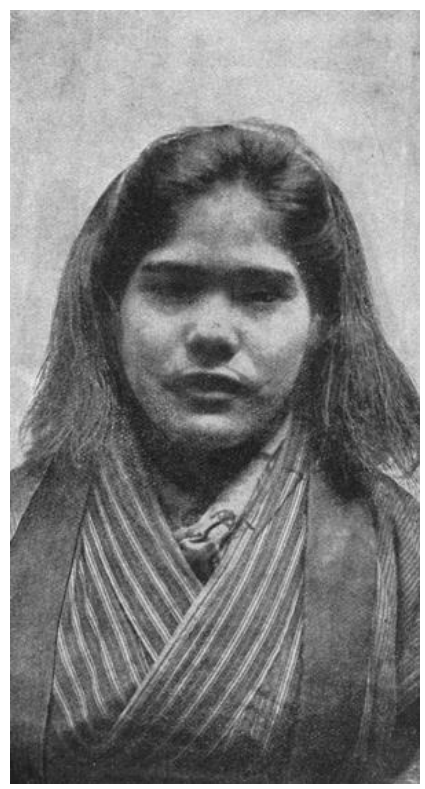

Figure 31. Shirake

Frederick Starr, The Ainu Group at the Saint Louis Exposition, Chicago: Open Court Pub, 1904 


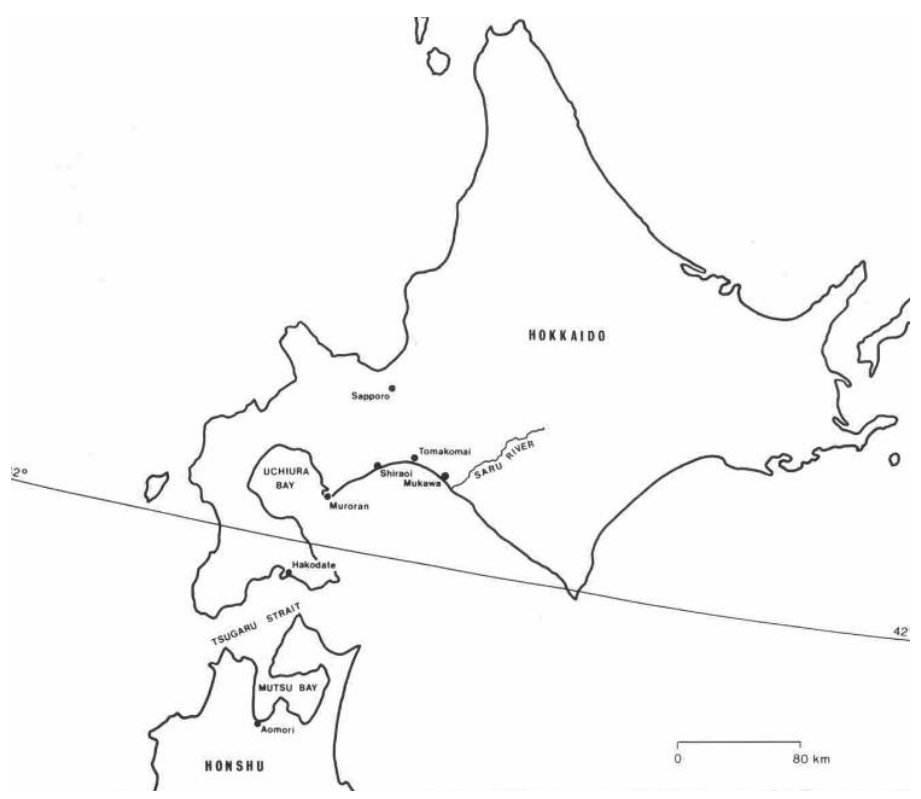

Figure 32. Map of Hokkaido

Vanstone, James W. "The Ainu Group at the Louisiana Purchase Exposition, 1904." Arctic Anthropology 30, no. 2, 1993. 77-91.

Figure 33. Bete Goro of Sapporo

Field Museum of Natural History, neg. no. 13206. Chicago.

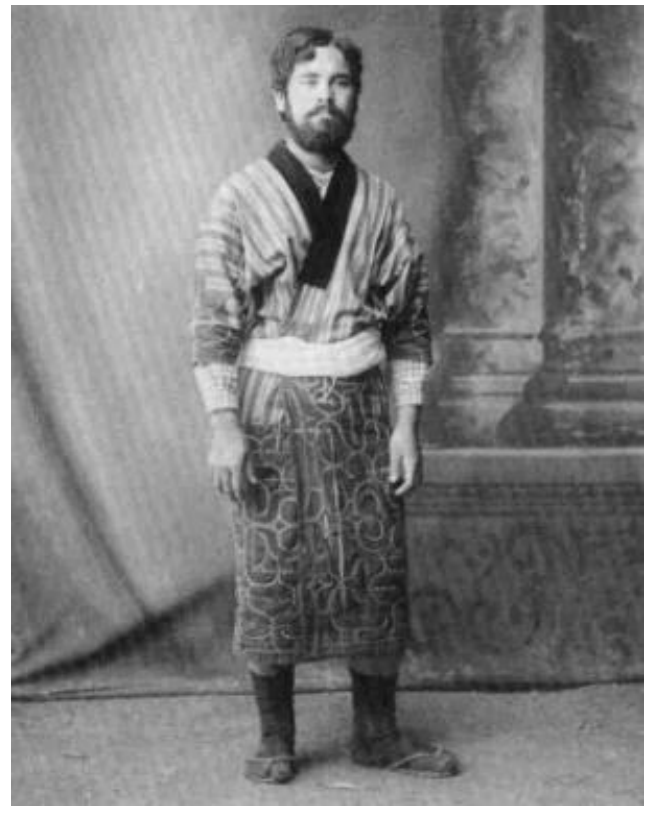

Figure 34. Map of a section of the southwest coast of Hokkaido James W Vanstone. "The Ainu Group at the Louisiana Purchase Exposition, 1904." Arctic Anthropology 30, no. 2, 1993. 77-91.

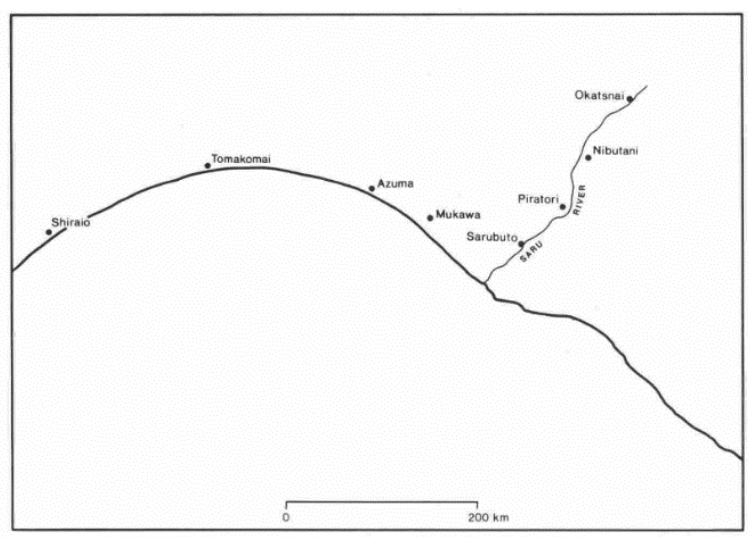




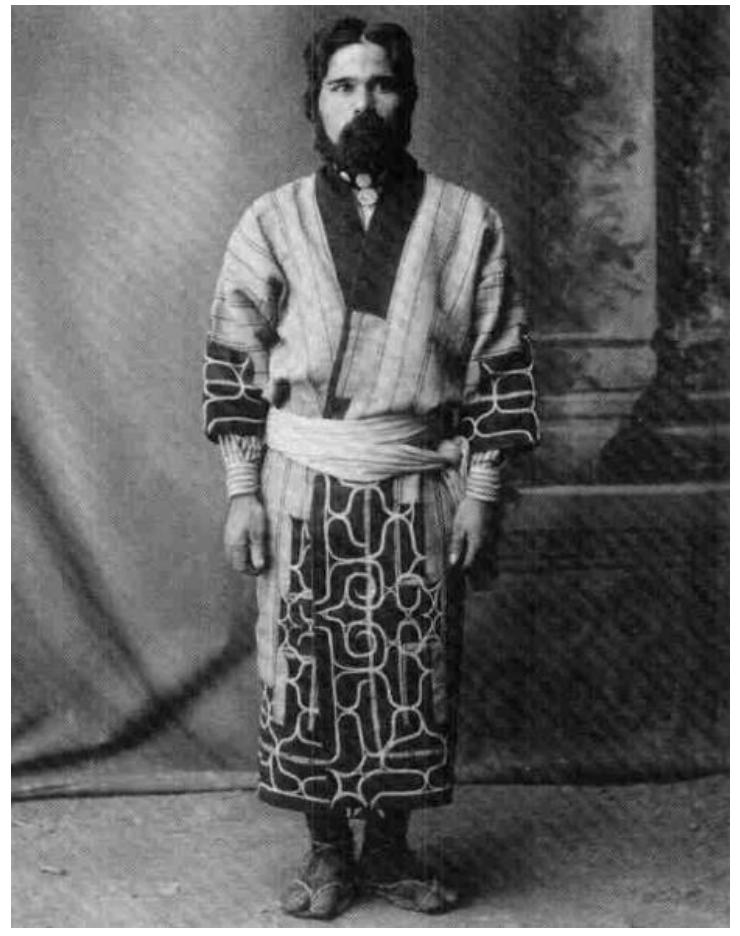

Figure 35. Kutoroge of Piratori

Field Museum of Natural History, neg. no. 13209. Chicago.

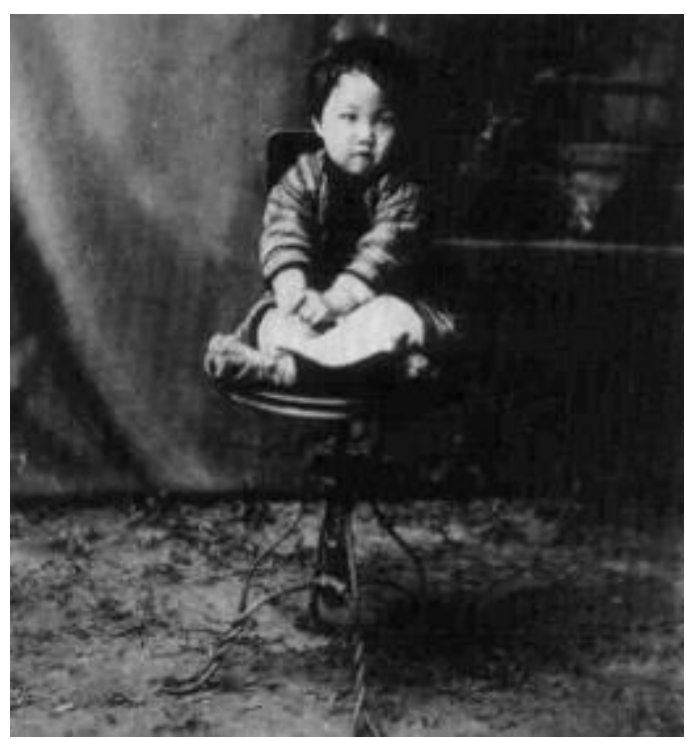

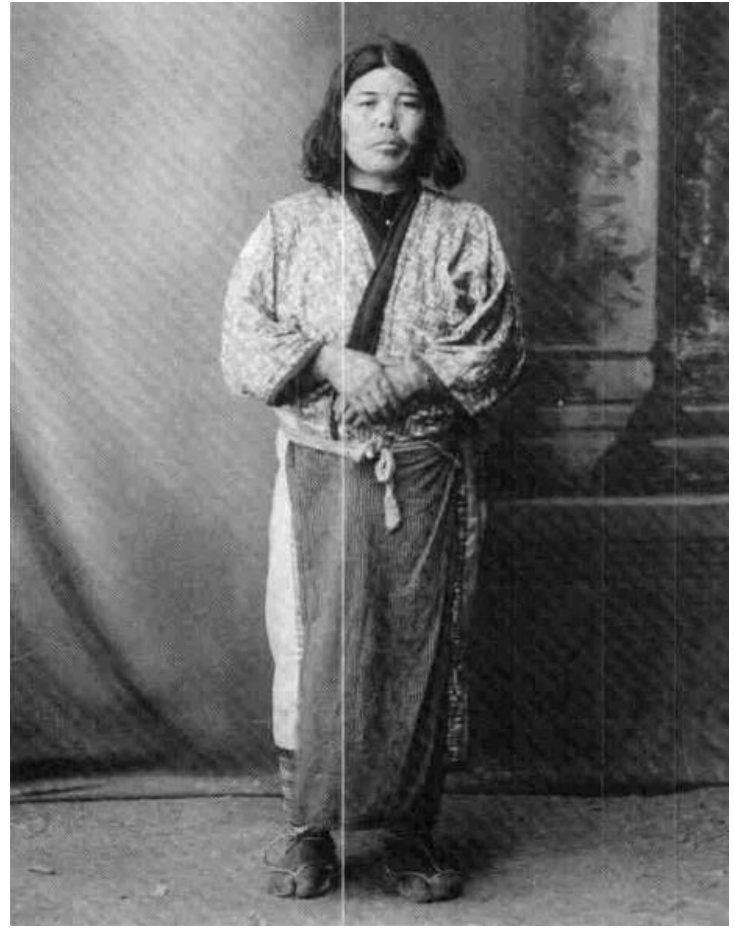

Figure 36. Shutratek, wife of Kutoroge

Field Museum of Natural History, neg. no. 13202. Chicago.

Figure 37. Kiko, daughter of Kutoroge and Shutratek

Field Museum of Natural History, neg. no. 13220. Chicago. 


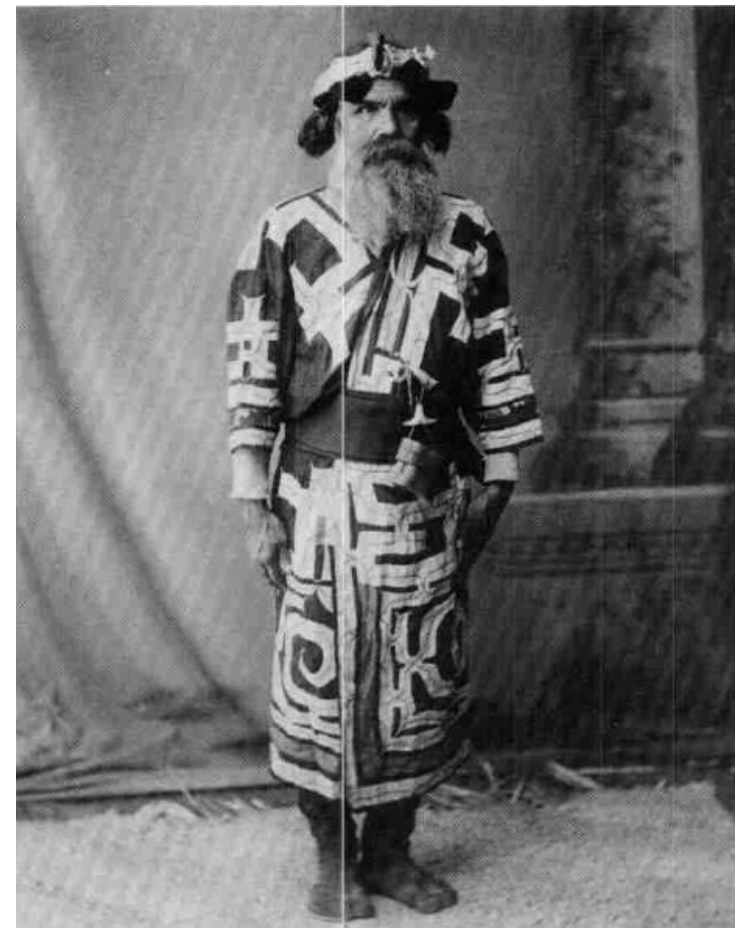

Figure 38. Sangyea of Piratori

Field Museum of Natural History, neg. no. 13213. Chicago.

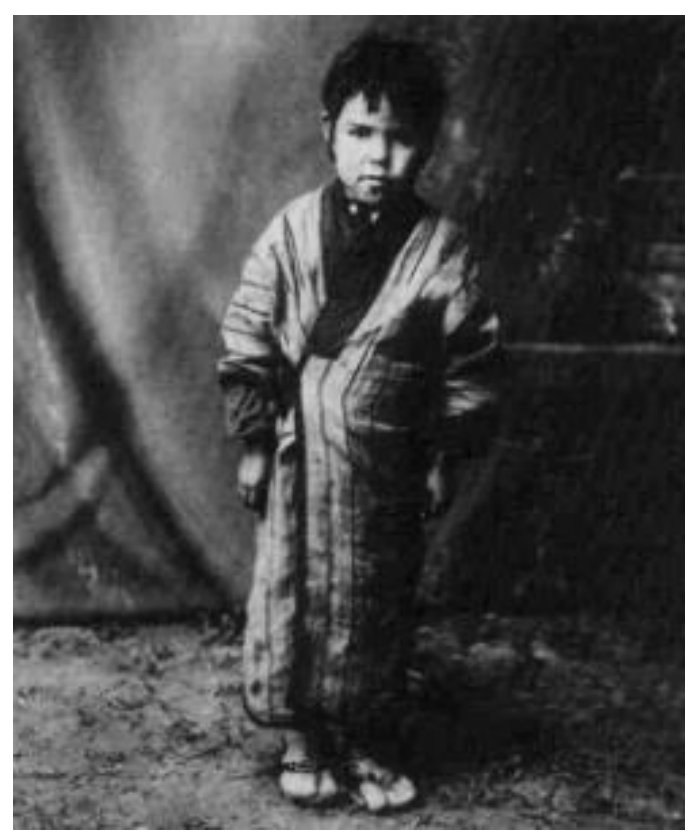

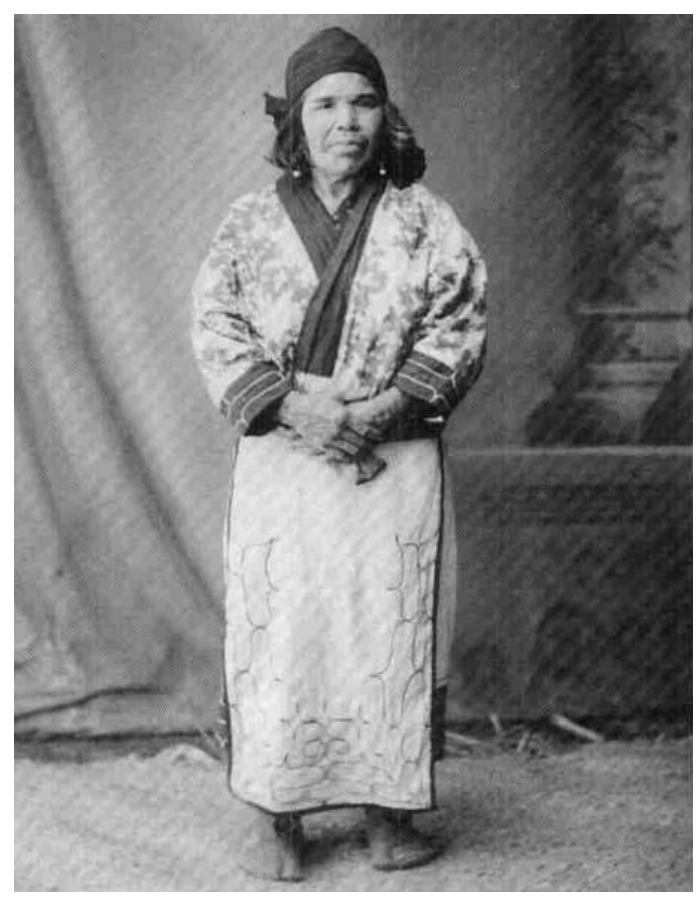

Figure 39. Santukno, wife of Sangyea

Field Museum of Natural History, neg. no. 13197. Chicago.

Figure 40. Kin, daughter of Sangyea and Santukno

Field Museum of Natural History, neg. no. 13219. Chicago. 


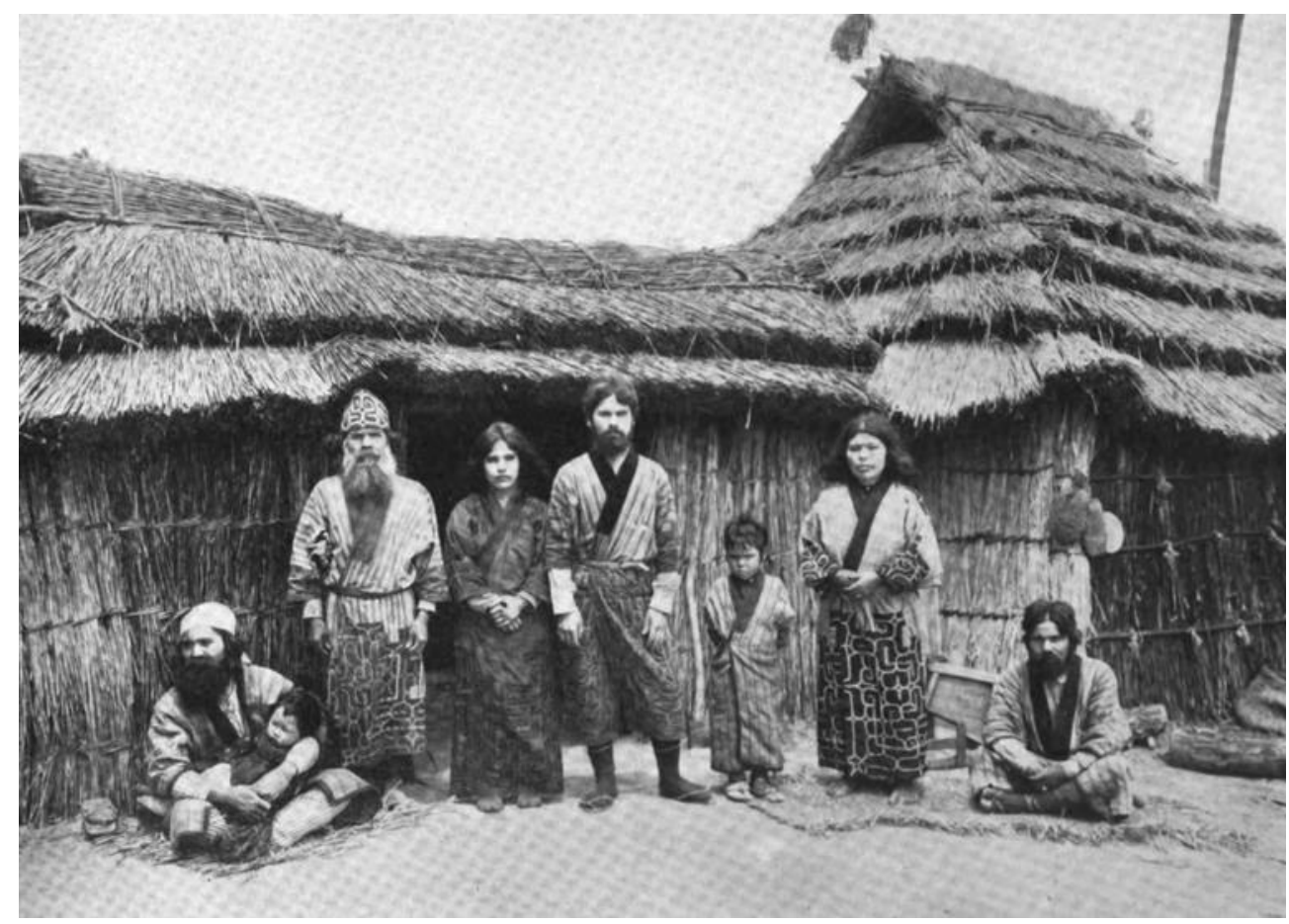

Figure 41. Hairy Ainu From Far North, St. Louis: Official Photographic Company of the Louisiana Purchase Exposition, c.1904.

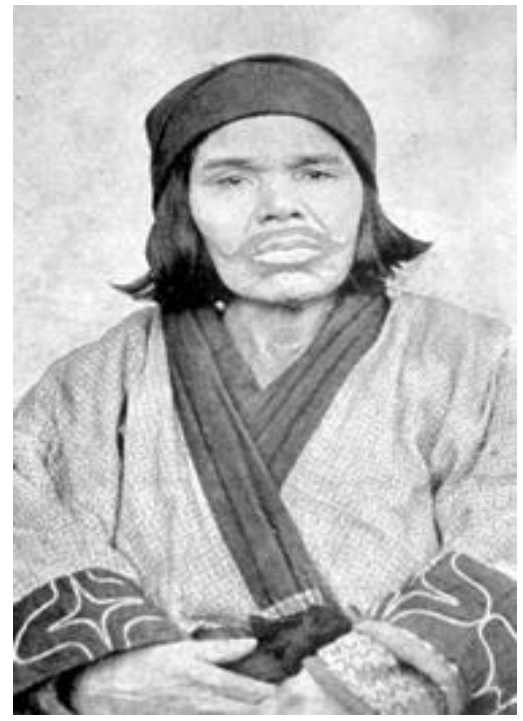

Figure 42 Ainu woman wearing attush garment with magical embroidery, ca. 1900.

"Tattooing Among Japan's Ainu People." Skin and Ink Magazine, February. p. 60-68. 


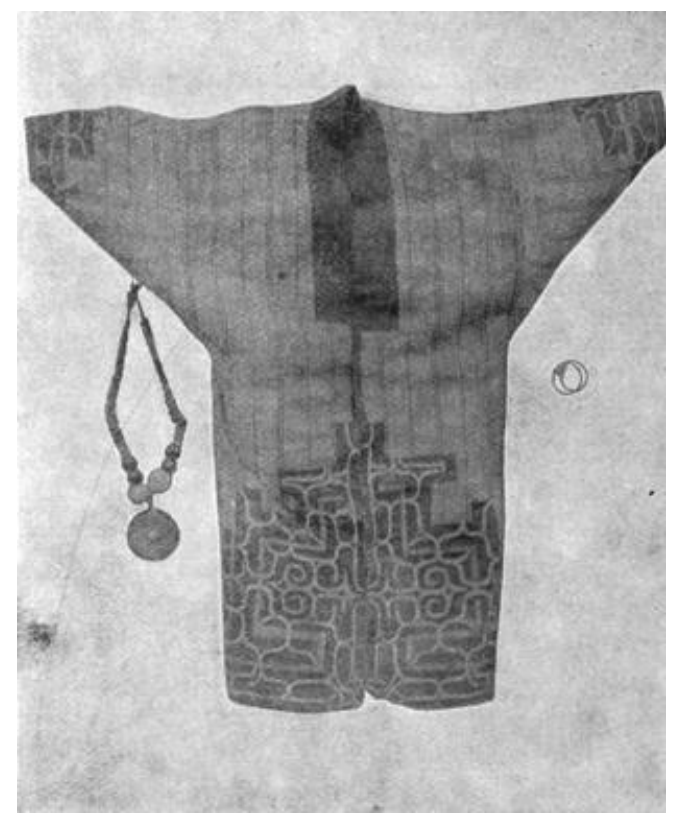

Figure 43. Woman's Dress of Elm-Bark Cloth, Earrings, and Necklace Frederick Starr, The Ainu Group at the Saint Louis Exposition, Chicago: Open Court Pub, 1904. 


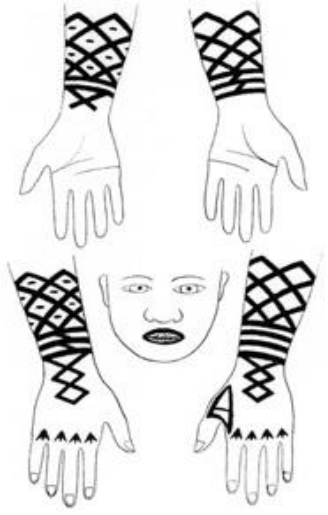

Figure 44. Ainu forearm tattoos with three, five and seven-strand network patterns.

"Tattooing Among Japan's Ainu People." Skin and Ink Magazine, February. p. 60-68.

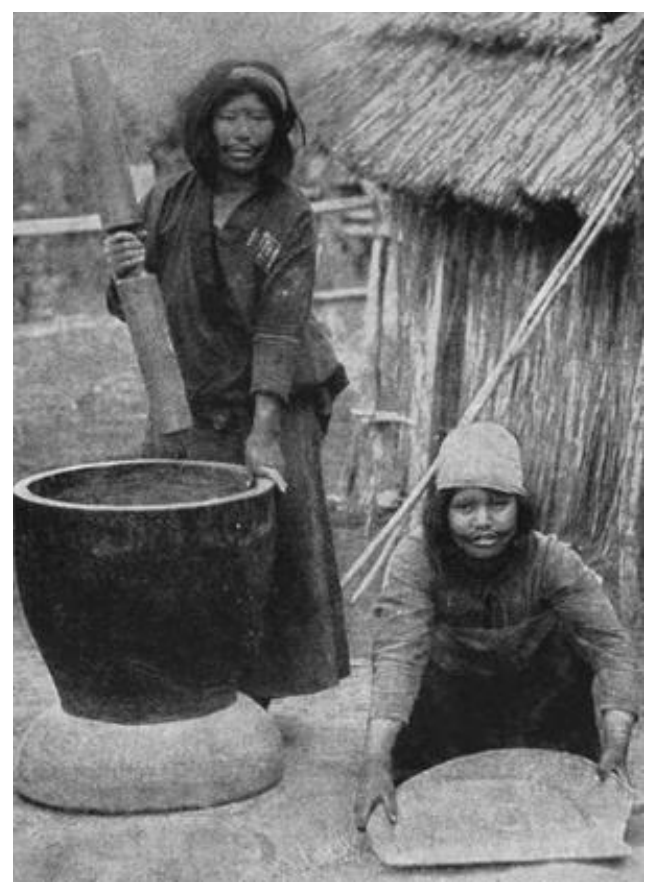

Figure 45. Women Pounding Millet

Frederick Starr, The Ainu Group at the Saint Louis Exposition, Chicago: Open Court Pub, 1904. 


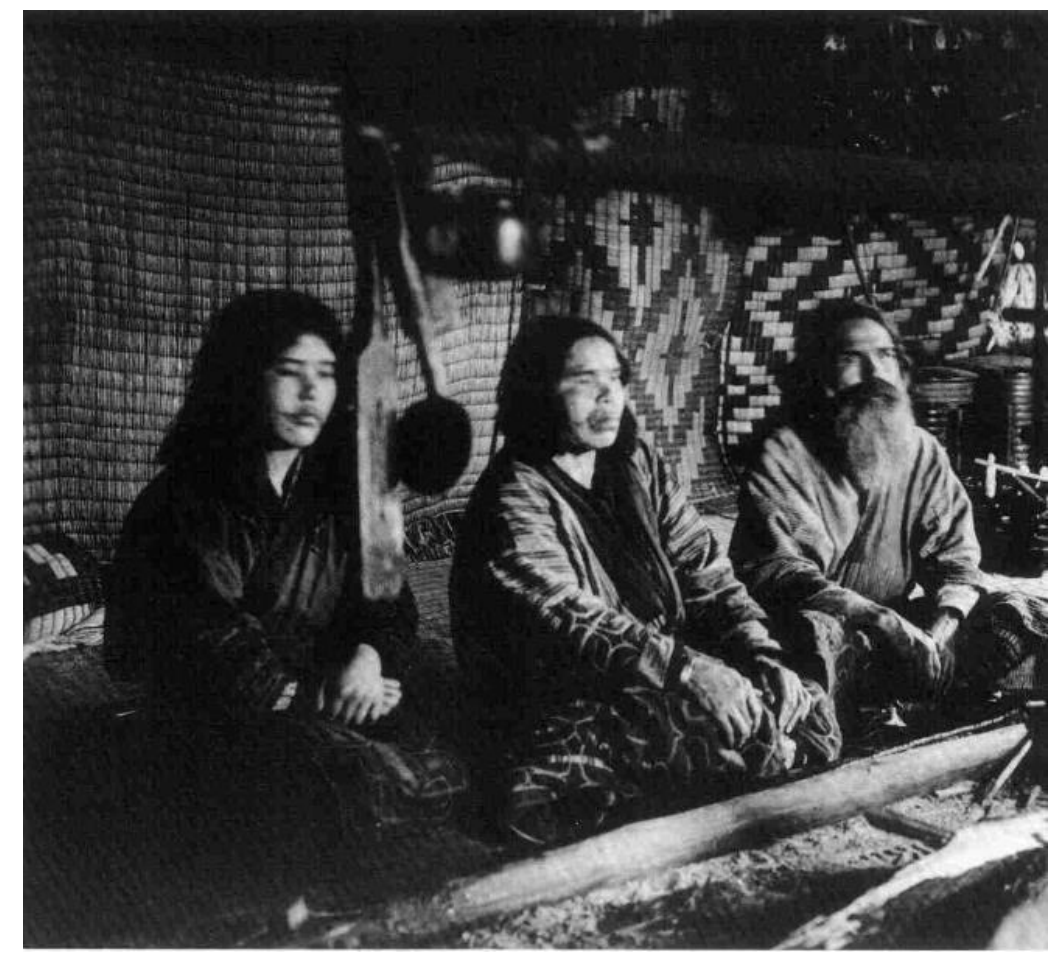

Figure 46. Interior of the Ainu house at the Louisiana Purchase Exposition

Field Museum of Natural History, neg. no. 13223. Chicago.

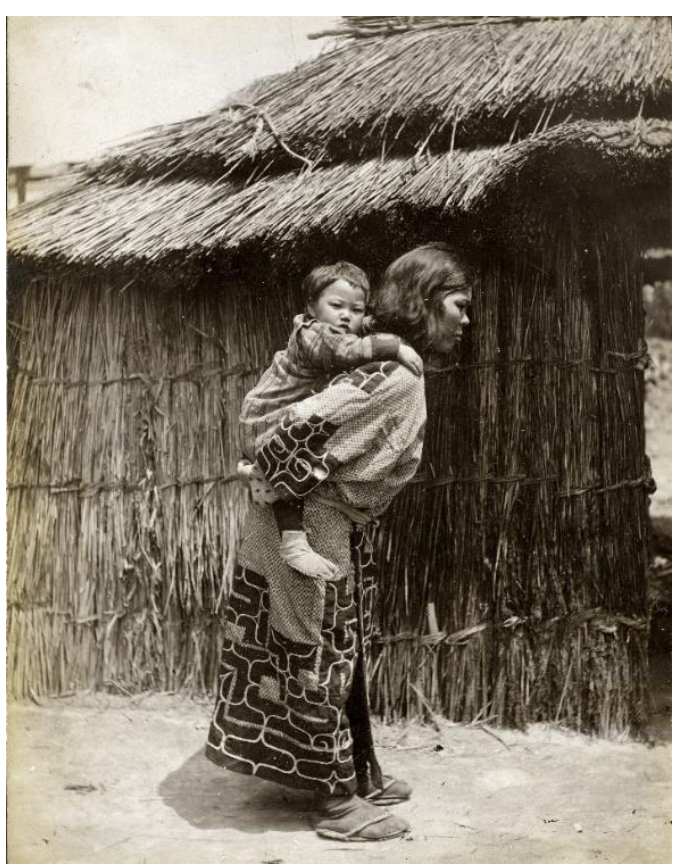

Figure 47."Ainu mother and child." Department of Anthropology, Japanese exhibit, 1904 World's Fair 


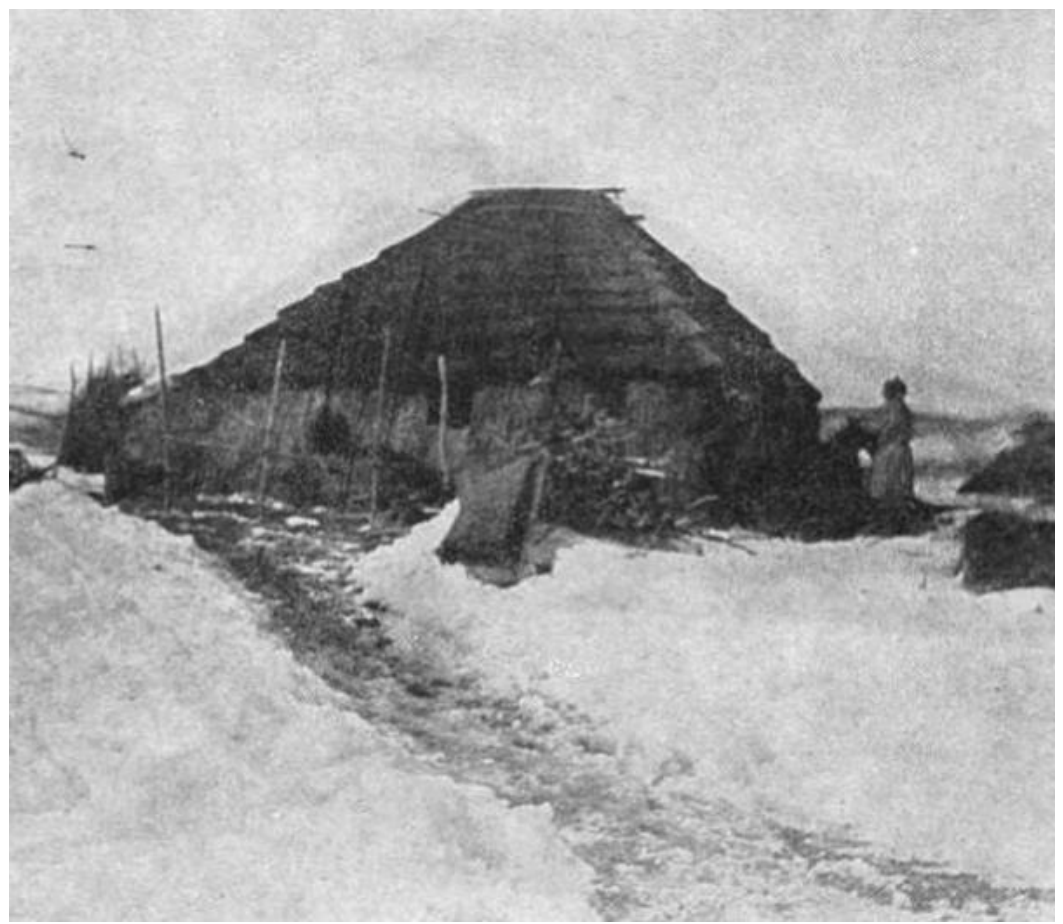

Figure 48. House in Demolution: Shiraoi

Frederick Starr, The Ainu Group at the Saint Louis Exposition, Chicago: Open Court Pub, 1904

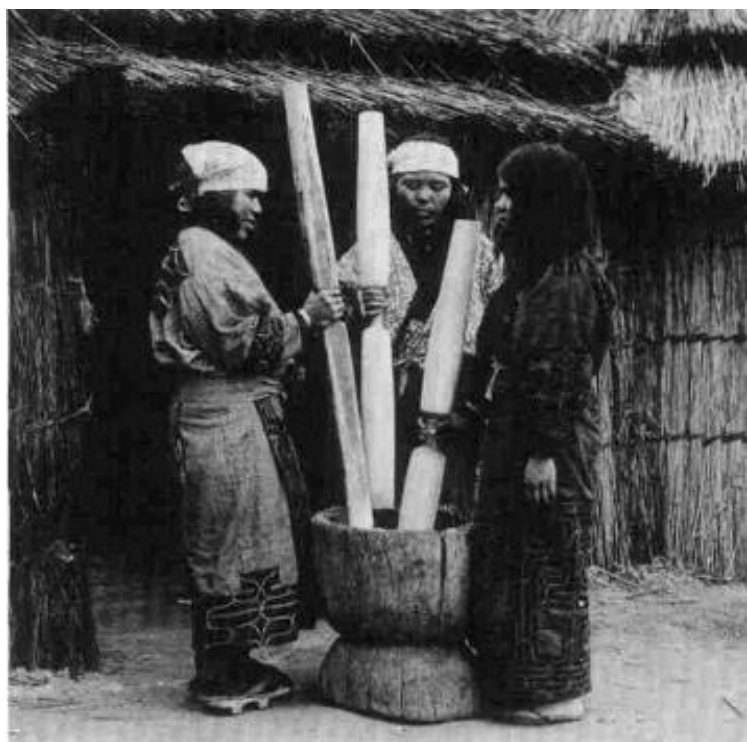

Figure 49. The three Ainu women using a mortar and pestles at the Louisiana Purchase Exposition Field Museum of Natural History, neg. no. 13224. Chicago. 


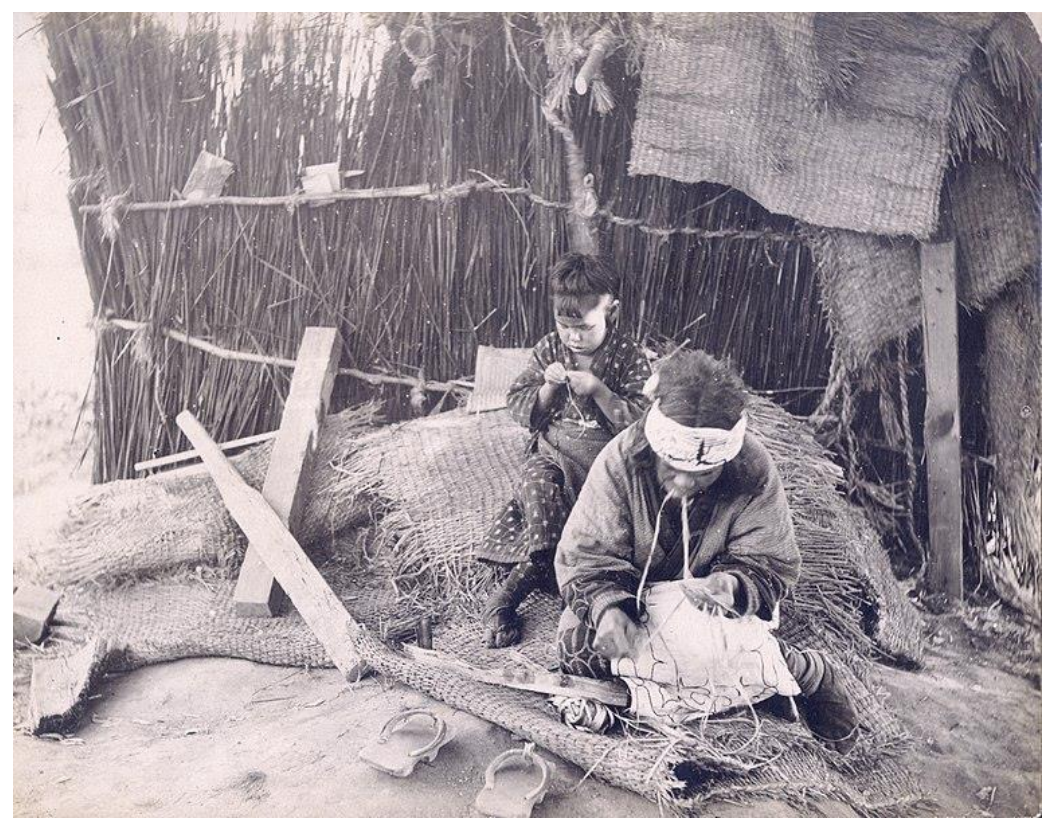

Figure 50. "Ainu Weaver." Department of Anthropology, Japanese exhibit, 1904 World's Fair

Figure 51. The Ainu group at the Louisiana Purchase Exposition Field Museum of Natural History, neg. no. 13228. Chicago.

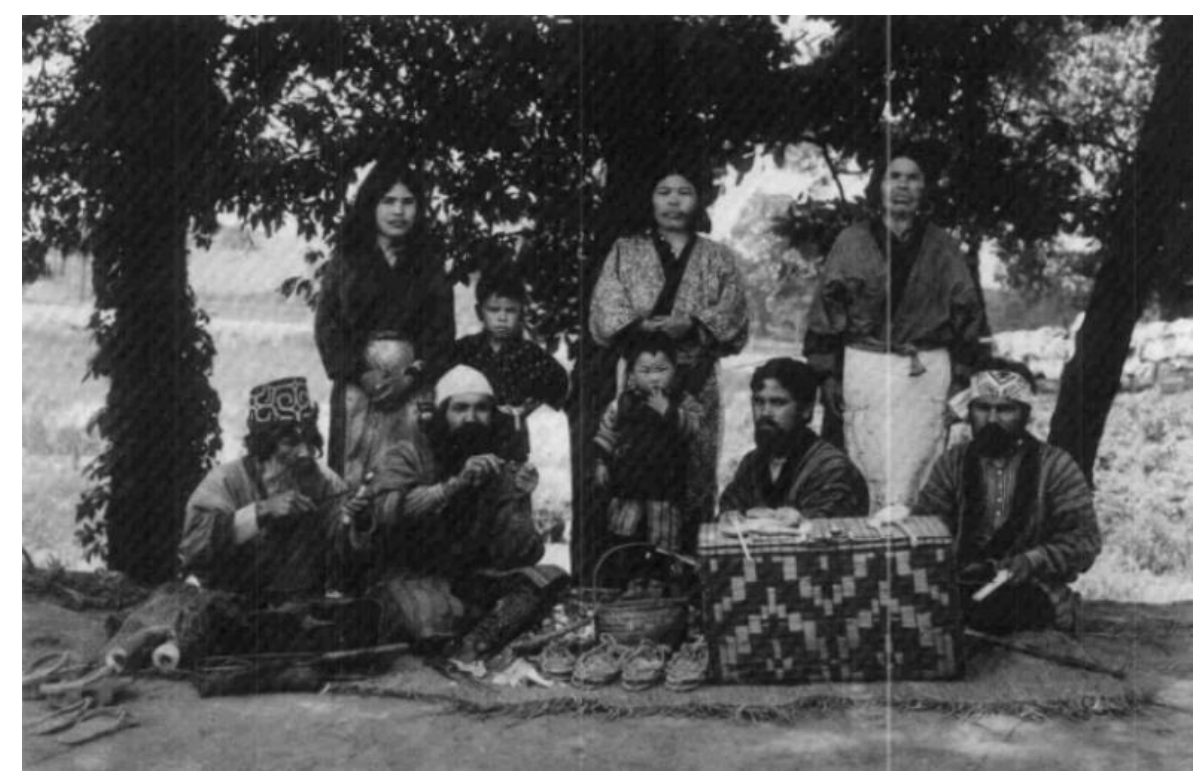


Bibliography

Aihara, Kyaoko. Geisha: A Living Tradition. London: Carlton, 2005.

Anesaki, Masaharu. Art, Life, and Nature in Japan. Rutland, Vt: C.E. Tuttle, 1973.

Anderson, Mark, Ph. D. Japan and the Specter of Imperialism. 1st Ed. ed. New York: Palgrave Macmillan, 2009.

Baba, Marietta. "To the End of Theory-Practice 'apartheid': Encountering the World." Ethnographic Praxis in Industry Conference Proceedings, no. 1, 2005. 205-217.

Barry, Peter. Beginning Theory. T.R. Publications Pvt. Ltd. 2006.

Bartlett, R. "Japonisme and Japanophobia: The Russo-Japanese War in Russian Cultural Consciousness." Russian Review -Stanford Then Columbus- 67, no. 1, 2008. 8-33.

Beasley, W. G. The Meiji Restoration. Stanford, Calif: Stanford University Press, 1972.

Bell, David. Ukiyo-e Explained. Folkestone, Kent: Global Oriental, 2004.

Benfey, Christopher E. G. The Great Wave: Gilded Age Misfits, Japanese Eccentrics, and the Opening of Old Japan. New York: Random House, 2003.

Bennitt, Mark. History of the Louisiana purchase exposition: comprising the history of the Louisiana territory, the story of the Louisiana purchase and a full account of the great exposition, embracing the participation of the states and nations of the world, and other events of the St. Louis World's Fair of 1904. Saint Louis: Universal Exposition Pub. Co., 1905.

Bolger, Doreen, and Metropolitan Museum of Art (New York, N.Y.). In Pursuit of Beauty: Americans and the Aesthetic Movement. New York: Metropolitan Museum of Art, 1986.

"Book Review: The Ainu Group at the St. Louis Exposition." The Journal of Education 60, no. 13, 1904. 223.

Breitbart, Eric. A World on Display: Photographs from the St. Louis World's Fair, 1904. 1st ed. Albuquerque: University of New Mexico Press, 1997.

Buchler, Walter. "The Geisha Girl." Dancing Times Sept 1929, P 532-534. Illus. (1929).

Burris, John P. Exhibiting Religion: Colonialism and Spectacle at International Expositions, 1851-1893. Studies in Religion and Culture. Charlottesville: University Press of Virginia, 2001. 
Burke, Peter. "The History and Theory of Reception" Lloyd, Howell A. Reception of Bodin. Brill's Studies in Intellectual History, Volume 223. Brill, 2013.

Çelik Zeynep, and Jay, Martin. "Speaking Back to Orientalist Discourse." Essay. In Speaking Back to Orientalist Discourse, 395-414, 2014.

Choi, Jung-Bong. "Mapping Japanese Imperialism onto Postcolonial Criticism." Social Identities 9, no. 3 (2003): 325-39. doi:10.1080/1350463032000129957.

Christ, Carol. "Japan's Seven Acres: Politics and Aesthetics at the 1904 Louisiana Purchase Exposition." Gateway Heritage 17: 2 (1996): 2-15.

Christ, Carol Ann. ""the Sole Guardians of the Art Inheritance of Asia": Japan at the 1904 St. Louis World's Fair." Positions: East Asia Cultures Critique 8, no. 3, 2000. 675-709.

Clapp, Priscilla, and Joint Committee on Japanese Studies. Mutual Images: Essays in AmericanJapanese Relations. Edited by Akira Iriye. Harvard Studies in American-East Asian Relations, 7. Cambridge: Harvard University Press, 1975.

Clevenger, Martha R. "Through WesternEyes: Americans Encounter Asians at the Fair." Gateway Heritage 17: 2, 1996. 42-51.

Collcutt, Martin, Isao Kumakura. Cultural Atlas of Japan. New York: Facts on File, 1988.

Drea, Edward J. Japan's Imperial Army: Its Rise and Fall, 1853-1945. Kansas: University Press of Kansas, 2009.

Everett, Marshall. The book of the Fair: the greatest exposition the world has ever seen photographed and explained, a panorama of the St. Louis exposition. Philadelphia: P.W. Ziegler, 1904.

"Fashion: In America: The Norell Kimono." Vogue Apr 01, 1965: ProQuest. Web. 12 Feb. 2018.

Final report of the Louisiana purchase exposition commission. Washington: Gov't Print Off, 1906.

Fletcher, H, Phillips. The St. Louis Exhibition, 1904. London, B.T. Batsford, 1905.

Foucault Michel. Excerpts from The History of Sexuality: Volume I: An Introduction. Natoli, Joseph P, Linda Hutcheon, and Rogers D. Spotswood Collection. A Postmodern Reader. Albany: State University of New York Press, 1993.333-341.

Gallagher, John, (Translator). Geisha: A Unique World of Tradition, Elegance, and Art. London: Produced by PRC Pub, 2003. 
Godement, François. The New Asian Renaissance: From Colonialism to the Post-Cold War. London: Routledge, 1997.

Goldstein-Gidoni, O. "Kimono and the Construction of Gendered and Cultural Identities." Ethnology 38, 1999: 351-370.

Gordon, Bill. Explanations of Japan's Imperialistic Expansion, 1894-1910. December 2003. http://wgordon.web.wesleyan.edu/papers/imperialism.html (Accessed September $8^{\text {th }}$, 2018).

Hägerdal, Hans. Responding to the West: Essays on Colonial Domination and Asian Agency. Icas Publications Series. Edited Volumes, 5. Amsterdam: Amsterdam University Press, 2009.

Hanson, John Wesley. The Official History of the Fair, St. Louis, 1904: The Sights and Scenes of the Louisiana Purchase Exposition. N.p. 1904.

Hearn, Lafcadio. Glimpses of Unfamiliar Japan. Boston: Houghton Mifflin, 1894.

Hearn, Lafcadio. Japan: An Attempt at Interpretation. New York: The Macmillian Co.1904.

Hoffenberg, Peter H. An Empire on Display: English, Indian, and Australian Exhibitions from the Crystal Palace to the Great War. Berkeley: University of California Press, 2001.

Holub, Robert C. Reception Theory: A Critical Introduction. New Accents. London: Methuen, 1984.

Hoshi, Hajime. Handbook of Japan and Japanese Exhibits at World's Fair, St. Louis, 1904. N.p.1904.

Jenkins, D.. Images of a Changing World: Japanese Prints of the Twentieth Century. Portland Art Museum, 1983.

Kakuzo, Okakura. The Book of Tea. New York: Duffield \& Co., 1919.

Karlin, Jason G. "The Gender of Nationalism: Competing Masculinities in Meiji Japan." Journal of Japanese Studies 28, no. 1, 2002. 41-77.

Kemp, Wolfgang. "The Work of Art and Its Beholder: The Methodology of the Aesthetic of Reception." Subjects of Art History / Ed. by Mark A. Cheetham; Michael Ann Holly, 1998. 180-196.

Kikuchi, Yūko. Japanese Modernization and Mingei Theory: Cultural Nationalism and Oriental Orientalism. London: Routledge Curzon, 2004.

Kim, Laura. The influence of St. Louis 1904 World's Fair on Japonisme that appeared in periodicals. M.S. University of Missouri-Columbia, 2012. 
Kirk, A. M. "Japonisme and Femininity: A Study of Japanese Dress in British and French Art and Society, c. 1860-c. 1899.” Costume, Vol. 42, 2008.

Kita, Sandy. The Floating World of Ukiyo-e: Shadows, Dreams, and Substance. New York: Abrams in Association with the Library of Congress, 2001.

Knight, Eliza. The History and Culture of Geisha. August 12, 2008. http://www.historyundressed.com/2008/08/history-and-culture-of-japanese-geisha.html (Accessed September $\left.10^{\text {th }}, 2018\right)$.

Kolig, Erich, Vivienne S. M Angeles, and Sam Wong. Identity in Crossroads Civilizations: Ethnicity, Nationalism and Globalism in Asia. Icas Publications Series. Edited Volumes, 8. Amsterdam: Amsterdam University Press, 2009.

Kopytoff, I. The cultural biography of things: commoditization as process. In Appadurai, A. (Eds.). The social life of things: Commodities in cultural perspective. Cambridge University Press. 1986.

Krutak, Lars. "Tattooing Among Japan's Ainu People," Skin and Ink Magazine, November 27, 2012. 60-68.

Lai, Selena, Sōshitsu Sen, XV, Karen Tiegel, Freeman Spogli Institute for International Studies, and Stanford Program on International and Cross-Cultural Education. Tea and the Japanese Tradition of Chanoyu. Stanford, CA: Stanford Program on International and Cross-Cultural Education (SPICE), 2005.

Larking, Matthew. "Nihonga didn't ignore the West,” Tokyo: Japan Times.2015.

Lehmann, J-P. "Old and New Japonisme: The Tokugawa Legacy and Modern European Images of Japan." Modern Asian Studies, Vol. 18, No. 4, Special Issue: Edo Culture and Its Modern Legacy, 1984. 757-768.

Lone S. Japan's First Modern War: Army and Society in the Conflict with China, 1894-95, 1994.

Louisiana Purchase Exposition Saint Louis, Mo.and Halsey C Ives. Official Catalogue of Exhibitors: Universal Exposition, St. Louis, U.S.A. 1904: Division of Exhibits ...

Department B, Art, Halsey C. Ives, Chief. Rev. Ed. ed. St. Louis, Mo.: Published for the Committee on Press and Publicity by the Official Catalogue, 1904.

Louisiana Purchase Exposition Saint Louis, Mo. and Koji Oi. Louisiana Purchase Exposition, St. Louis in 1904: A Collection of Official Guidebooks and Miscellaneous Publications. Kyoto: Eureka Press, 2009. 
Lowenstein, Major J. Official guide to the Louisiana Purchase Exposition at the city of St. Louis, state of Missouri, April 30th to December 1st, 1904, by authority of the United States of America. St. Louis: The Official Guide Co. 1904.

Lloyd, Howell A. Reception of Bodin. Brill's Studies in Intellectual History, Volume 223. Brill, 2013.

Maikoya. The Japanese Tea Ceremony Explained._Maikoya. Osaka, 2018. https://maiko.com/the-japanese-tea-ceremony-explained/ (Accessed February $\overline{\left.20^{\text {th }}, 2018\right)}$.

Mansfield, Stephen, and Photobank. Japan: Islands of the Floating World. Singapore: Times Editions, 1998.

Marra, Michele. Japanese Hermeneutics: Current Debates on Aesthetics and Interpretation. Honolulu: University of Hawai'i Press, 2002.

Martin, R. \& Koda, H. Orientalism -Visions of The East in Western Dress. Harry N. Abrams Inc., New York, 1994.

McCracken, G. Culture \& Consumption. Indiana University Press. 1988.

Marcosson, I. F. “Japan’s Extraordinary Exhibit.” The World’s Work, 1904.

Michener, James A. The Floating World. Honolulu: University of Hawaii Press, 1983.

Milhaupt, Terry Satsuki. Kimono: A Modern History. London: Reaktion Books, 2014.

Mizuta, Miya. E. "Fair Japan: On Art and War at the Saint Louis World's Fair, 1904." Discourse, Vol. 28. (1), 2006. 28-52.

Munro, L. "Investing World's Fairs: A Historiography," Studies in Latin American Popular Culture, Vol. 28, 2010.

Museum of Fine Art Boston. Interior of a Bathhouse, https://collections.mfa.org/objects/467811 (Accessed November 30th, 2019).

National Diet Library. Second London International Exposition of 1862. 2010. http://www.ndl.go.jp/exposition/e/s1/1862-1.html (Accessed July 19 ${ }^{\text {th }}, 2019$ ).

National Diet Library. Second Paris International Exposition of 1867. 2010. http://www.ndl.go.jp/exposition/e/s1/1867.html (Accessed July 19 ${ }^{\text {th }}, 2019$ ).

National Diet Library. Vienna International Exposition of 1873. 2010. http://www.ndl.go.jp/exposition/e/s1/1873-2.html (Accessed July 19 ${ }^{\text {th }}, 2019$ ). 
Parezo, Nancy J, and Don D Fowler. Anthropology Goes to the Fair: The 1904 Louisiana Purchase Exposition. Critical Studies in the History of Anthropology. Lincoln: University of Nebraska Press, 2007.

Rau, William H. The greatest of expositions completely illustrated: official publication. St. Louis: Official Photographic Company of the Louisiana Purchase Exposition, 1904.

Redding, Paul, "Georg Wilhelm Friedrich Hegel", The Stanford Encyclopedia of Philosophy (Summer 2018 Edition), Edward N. Zalta (ed.), https://plato.stanford.edu/archives/sum2018/entries/hegel/ (Accessed September $4^{\text {th }}$, 2018).

Rickard, J. First Sino-Japanese War (1894-1895), October 31, 2013. http://www.historyofwar.org/articles/wars_first_sino_japanese.html (Accessed March $\left.22^{\text {nd }}, 2018\right)$.

Rowland, F. D. \& Louisiana Purchase Exposition Co. (1913). The Universal Exposition of 1904.Meeting Louisiana Purchase Exposition. 2 v.

Rydell, R. W. All the World's Fair: Visions of Empire at American International Expositions, 1876-1916.Chicago: University of Chicago Press, 1984.

Rydell, Robert W, John E Findling, and Kimberly D Pelle. Fair America: World's Fairs in the United States. Washington, DC: Smithsonian Institution Press, 2000.

Said, Edward W. Culture and Imperialism. 1St ed. New York: Knopf, 1993.

Said, Edward W. Orientalism. London: Routledge \& Kegan Paul Ltd.1978.

Sakuae M, and Reid D. "Making Tea in Place: Experiences of Women Engaged in a Japanese Tea Ceremony." Journal of Occupational Science 19, no. 3 2012: 283-91. doi:org/10.1080/14427591.2011.610775.

Sangjung, Kang. "Post-Colonialism and Diasporic Space in Japan." Inter-Asia Cultural Studies 2, no. 1,2001. 137-44.

Satō, Dōshin, and 道信 (1956-) 佐藤. Modern Japanese Art and the Meiji State: The Politics of Beauty. Los Angeles: Getty Research Institute, 2011.

Sawant, Dr. Datta. Perspectives on Post-Colonial Theory: Said, Spivak and Bhabha. Literary Endeavor. 2. 2011. 129-135.

"Says Asia's Salvation Is Stake of The War." New York Times (1857-1922), Mar 20, 1904. https://search-proquest-com.www.libproxy.wvu.edu/docview/96435035?accountid=2837 (Accessed September 10 ${ }^{\text {th }}, 2018$ ). 
Schwarz, Henry, and Sangeeta Ray. A Companion to Postcolonial Studies: An Historical Introduction. Blackwell Companions to Literature and Culture. Chichester: John Wiley \& Sons, 2007.

Shimazu, N. "Patriotic and Despondent: Japanese Society at War 1904-5," The Russian Review, Vol. 67, 2008. 34-49.

Smithsonian Institution Libraries and Robert W Rydell. The Books of the Fairs: Materials About World's Fairs, 1834-1916, in the Smithsonian Institution Libraries. Smithsonian Institution Libraries Research Guide, No. 6. Chicago: American Library Association, 1992.

Spacey, John. “Seiza: Crippling Pain for Gaijin, Japan Talk.” September 16, 2015. https://www.japan-talk.com/jt/new/seiza (Accessed July 19 ${ }^{\text {th }}, 2019$ ).

Stalker, Nancy K. Japan: History and Culture from Classical to Cool. Oakland, California: University of California Press, 2018.

Starr, Frederick. The Ainu Group at the Saint Louis Exposition. Chicago: Open Court Pub, 1904.

The exhibition of the Empire of Japan: official catalogue. St. Louis, Mo.: International Exposition, 1904.

The United States and the Opening to Japan, 1853. Office of the Historian, Foreign Service Institute United States Department of State, 2019. https://history.state.gov/milestones/1830-1860/opening-to-japan (Accessed September $\left.10^{\text {th }}, 2018\right)$.

The State Historical Society. St. Louis Post-Dispatch from The State Historical Society of Missouri Newspaper Collection, 1903-1905.

Tierney, Robert Thomas. Tropics of Savagery: The Culture of Japanese Empire in Comparative Frame. Asia Pacific Modern, 5. Berkeley: University of California Press, 2010.

Trentmann, F. “Crossing Divides: Consumption and globalization in history.” Journal of Consumer Culture, 2009.

Truax, Mike. The 1904 St. Louis World's Fair “100 Years of Memories.” N.p. West County Marketing Group, LLC.2004.

The Urasenke Foundation. wa kei sei jaku. San Francisco, 2013. http://www.urasenke.org/characters/index.html (Accessed September 10 ${ }^{\text {th }}, 2018$ ).

Vanstone, James W. "The Ainu Group at the Louisiana Purchase Exposition, 1904." Arctic Anthropology 30, no. 2, 1993. 77-91. 
Vital, Marcelo, and David Montgomery. 1904. 1st Ed. ed. Lawrence, Kan. Van Gogh's Ear, 2004.

Walker, John Brisben. Louisiana Purchase Exposition 1904. New York: Cosmopolitan Pub, 1904.

Walker, John Brisben. The Cosmopolitan: World's Fair, September 1904, Vol. Xxxvii, No. 5. Irvington-on-Hudson, N.Y.: Cosmopolitan Company, 1904.

Watters, Allison M. MOT, BA, Christine Pearce MOT, BA, Catherine L. Backman PhD, OT(C), FCAOT, Melinda J. Suto PhD, OT. "Occupational Engagement and Meaning: The Experience of Ikebana Practice.” Journal of Occupational Science 20:3,2013. 262-277.

Weedon, Chris. Feminist Practice and Poststructuralist Theory. Oxford, UK: B. Blackwell, 1987.

Weiss, Allen S. Zen Landscapes: Perspectives on Japanese Gardens and Ceramics. London: Reaktion Books, 2013.

Whitman, Arthur. "What to Look For -A Guide to Exhibits." New York Times (1923- Current file); New York, N.Y.19 Apr 1964: SMA26.

Williams, Patrick, and Laura Chrisman. Colonial Discourse and Post-Colonial Theory: A Reader. New York: Columbia University Press, 1994.

Willmann, Anna. "The Japanese Tea Ceremony." In Heilbrunn Timeline of Art History. New York: The Metropolitan Museum of Art, 2000-. April 2011. http://www.metmuseum.org/toah/hd/jtea/hd_jtea.htm (Accessed September 10 ${ }^{\text {th }}, 2018$ ).

Yamawaki, H. "Japan in the Beginning of the 20 ${ }^{\text {th }}$ Century." Japan Times, Tokyo, Japan. 1903.

Yengoyan, A. A. "Universalism and Utopianism, A review article." Comparative Studies in Society and History. Vol. 39. No. 4, 1997. 785-798.

Yengoyan, A. A. "World's Fairs and Expositions: Civilization and Culture," Retrieved from Lecture, April 11, Ellis Auditorium, University of Missouri, 2011.

Yoshihara, M. Embracing the East: White Women and American Orientalism. Oxford University Press.2003.

Zubrzycki, Genevieve. National Matters: Materiality, Culture and Nationalism. California: Stanford University Press, 2017. 